\title{
Structural Relationships of Pre-Tertiary Rocks in the Nevada Test Site Region, Southern Nevada
}

U.S. Geological Survey Professional Paper 1607 


\section{Structural Relationships of Pre-Tertiary Rocks in the Nevada Test Site Region, Southern Nevada}

By James C. Cole and Patricia H. Cashman

U.S. GEOLOGICAL SURVEY PROFESSIONAL PAPER 1607

A summary interpretation of complex, pre-middle Miocene deformation resulting from foreland-vergent and hinterland-vergent contraction, strike-slip faulting, and local extension in the southern Great Basin region surrounding the Nevada Test Site. This report was prepared in cooperation with the Nevada Operations Office,

U.S. Department of Energy, under Interagency Agreement DE-AI08-96NV11967

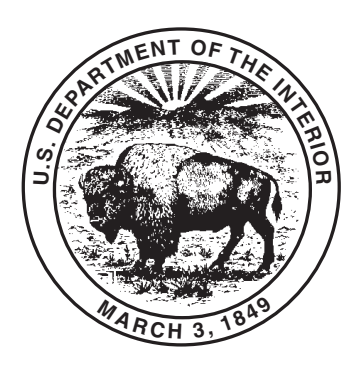




\title{
U.S. DEPARTMENT OF THE INTERIOR BRUCE BABBITT, Secretary
}

\author{
U.S. GEOLOGICAL SURVEY \\ Charles G. Groat, Director
}

For sale by U.S. Geological Survey, Information Services

Box 25286, Federal Center

Denver, CO 80225

\begin{abstract}
Any use of trade, product, or firm names in this publication is for descriptive purposes only and does not imply endorsement by the U.S. Government
\end{abstract}

Library of Congress Cataloging-in-Publication Data

Cole, James C.

Structural relationships of pre-Tertiary rocks in the Nevada Test Site

region, southern Nevada / by James C. Cole and Patricia H. Cashman

p. cm.-(U.S. Geological Survey professional paper ; 1607)

Includes bibliographical references

Supt. of Docs. no. : I 19.16: P1607

1. Geology, Structural-Nevada-Nevada Test Site. I. Cashman,

Patricia Hughes. II. Title. III. Series.

QE627.5.N3C65 1999

$551.8^{\prime} 09793-\mathrm{dc} 21$ 


\section{CONTENTS}

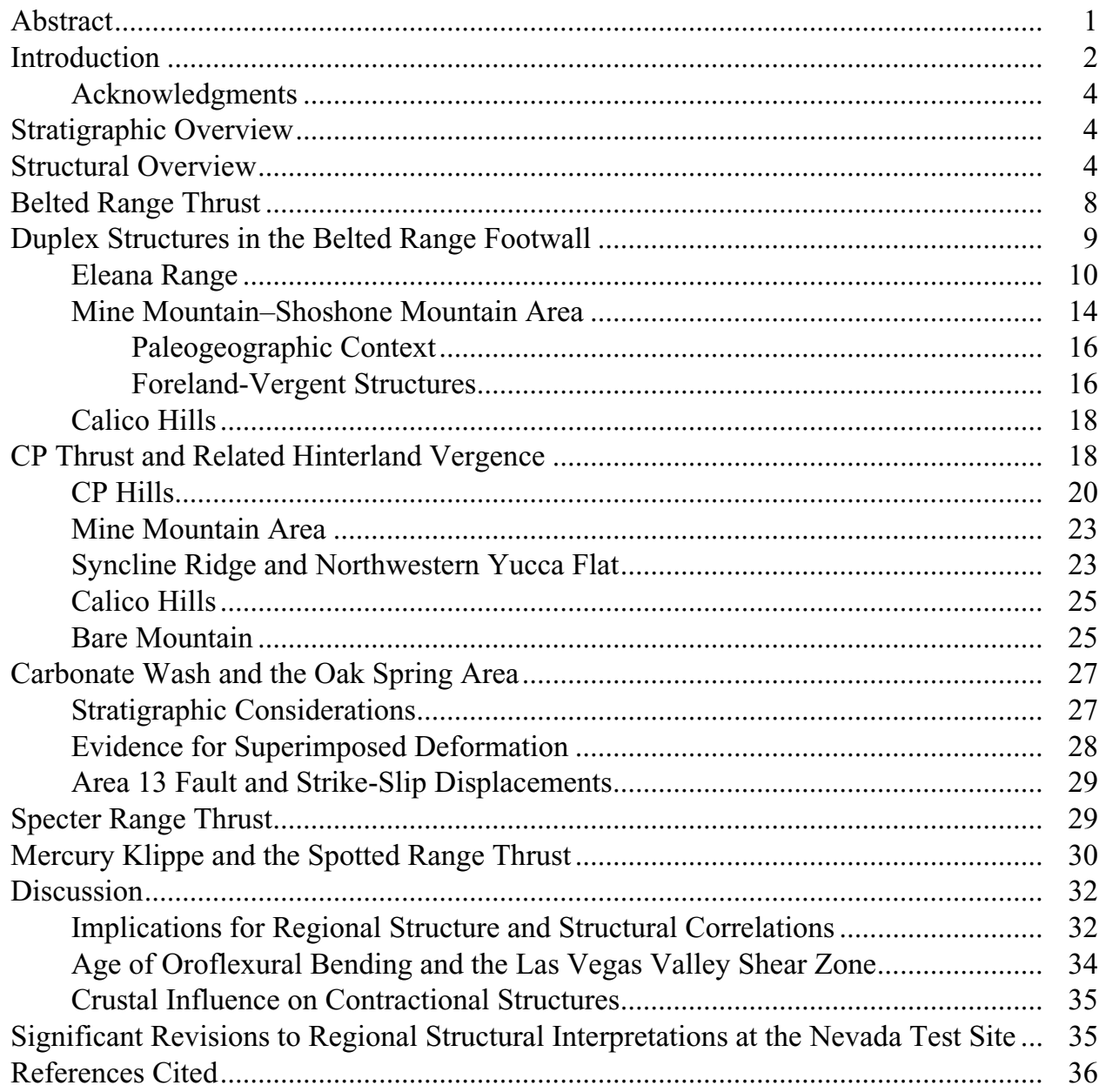

\section{FIGURES}

1. Regional location map showing major contractional structures in the southern Great Basin

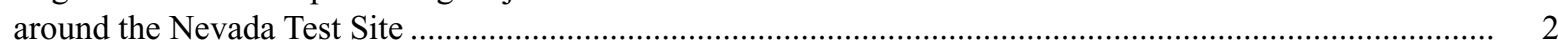

2. Stratigraphic column for pre-Tertiary rocks in the Nevada Test Site region ............................................... 5

3. Structural summary map of major contractional features in Paleozoic rocks in the

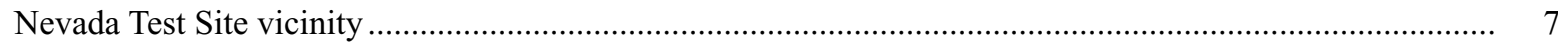

4. Geologic map and cross sections of the Eleana Range ....................................................................... 11

5-6. Stereograms showing poles to bedding for:

5. The Quartzite Ridge anticline and the northern Grouse Canyon plate ................................................ 13

7-9. Geologic maps of:

6 The overturned fold west of the Tippinip fault .............................................................................. 14

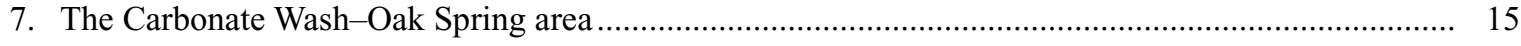

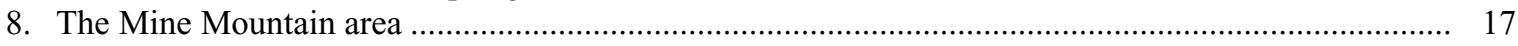

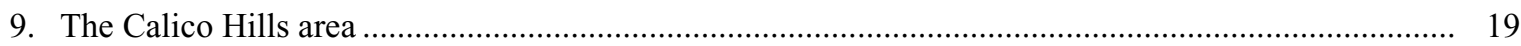


10. Stereogram showing poles to bedding for an overturned fold on the leading edge of the Calico thrust ......... 20

11. Geologic map of the CP Hills area........................................................................................... 21

12. Map showing stratigraphic units penetrated in drill holes beneath Yucca Flat ........................................ 24

13-14. Geologic maps of:

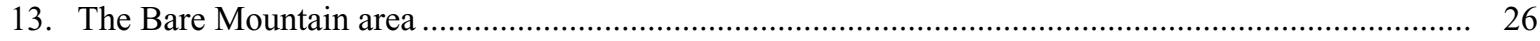

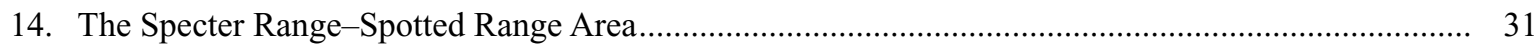




\title{
Structural Relationships of Pre-Tertiary Rocks in the Nevada Test Site Region, Southern Nevada
}

\author{
By James C. Cole ${ }^{1}$ and Patricia H. Cashman ${ }^{2}$
}

\begin{abstract}
This report summarizes the evidence for a revised interpretation of major structural features in the pre-Tertiary rocks of the region including and surrounding the Nevada Test Site. The thick miogeoclinal section of Late Proterozoic through Lower Permian sedimentary strata records major foreland-vergent thrust faulting, younger hinterland-vergent folding and thrusting, and local extension on low-angle normal faults. In addition, structural discontinuities in the northeastern part of the Nevada Test Site strongly suggest a broad, north-trending zone of sinistral strike-slip faulting that may have had a cumulative offset of many kilometers.

The major foreland-vergent structure in the region is the Belted Range thrust, which places Late Proterozoic on Mississippian strata. The thrust parallels bedding in the upper plate (Wood Canyon Formation) in most locations, but part of an overturned hanging-wall anticline is preserved in the northern Belted Range. Footwall deformation is characteristically an extensive zone of east- to southeast-verging duplexes. Within this zone, imbricate slices of more offshore (western) facies strata are emplaced over slices of more shelfal (eastern) facies strata. The thrust therefore appears to follow the miogeoclinal shelf-slope break; both may have been controlled by a preexisting contrast in crustal structure. Thermal exposure data indicate the Belted Range thrust probably did not propagate much farther toward the foreland than its present position.
\end{abstract}

An elongate zone of hinterland-vergent deformation, including the irregular folds and thrust faults of the $\mathrm{CP}$ thrust system, lies directly east and southeast of the Belted Range duplex zone. The folds are typically overturned and developed in kink-style bands; they commonly deform the leading edges of the Belted Range duplexes. Thrust faults in this system appear to be local in nature. They are characterized by

${ }^{1}$ U.S. Geological Survey, Box 25046, Mail Stop 913, Denver Federal Center, Denver, CO 80225-0046.

${ }^{2}$ Department of Geological Sciences, Mail Stop 172, University of Nevada-Reno, Reno, NV 89557-0138. large stratigraphic throws and extreme overturning of footwall strata. They appear to have initiated as steep breaks that flattened as they propagated upward within the miogeoclinal section and into the preexisting Belted Range thrust complex. Stratigraphic throw on these faults decreases in the direction of transport, in part because the total throw is partitioned into several thrust splays.

In the southern part of the Nevada Test Site, the foreland-vergent Specter Range thrust cuts the lower Paleozoic section but appears to die out eastward along strike beneath Mercury Valley. The Specter Range thrust was previously interpreted to connect with the Spotted Range thrust a short distance to the east, but stratigraphic considerations indicate the Spotted Range thrust is separate and structurally higher. Hinterland-vergent thrusts and folds form a discrete zone about 2 to $4 \mathrm{~km}$ behind the leading edge of the Spotted Range thrust; the origin of this zone is enigmatic.

Fault blocks exposed between northern Yucca Flat and lower Carbonate Wash, in the northeastern part of the Nevada Test Site, all belong to the footwall of the Belted Range thrust. However, their present side-by-side positions are inconsistent with simple contraction. Discrepancies in internal structural trends and stratigraphic levels among the blocks, on the other hand, are consistent with strike-slip offsets on at least three intersecting, north-striking faults. The apparent sense of slip on these faults is sinistral.

The prominent oroflexural bend in Paleozoic structural and stratigraphic trends coinciding with the northwest end of the Las Vegas Valley shear zone appears to predate the motion on the shear zone. The Las Vegas Valley shear zone accommodates differential Neogene extension between its northern and southern blocks but loses slip northwestward and dies out south of the Test Site. Neogene sedimentary rocks that were deposited in the area of oroflexural bending indicate no major syndepositional deformation. Although these sediments were somewhat deformed during slip on the Las Vegas Valley shear zone, this deformation was largely through passive drape-folding and fault truncation against the adjacent Paleozoic blocks. We conclude that the oroflex was largely in place prior to Miocene time and that it may have formed during post-Pennsylvanian thrusting. 


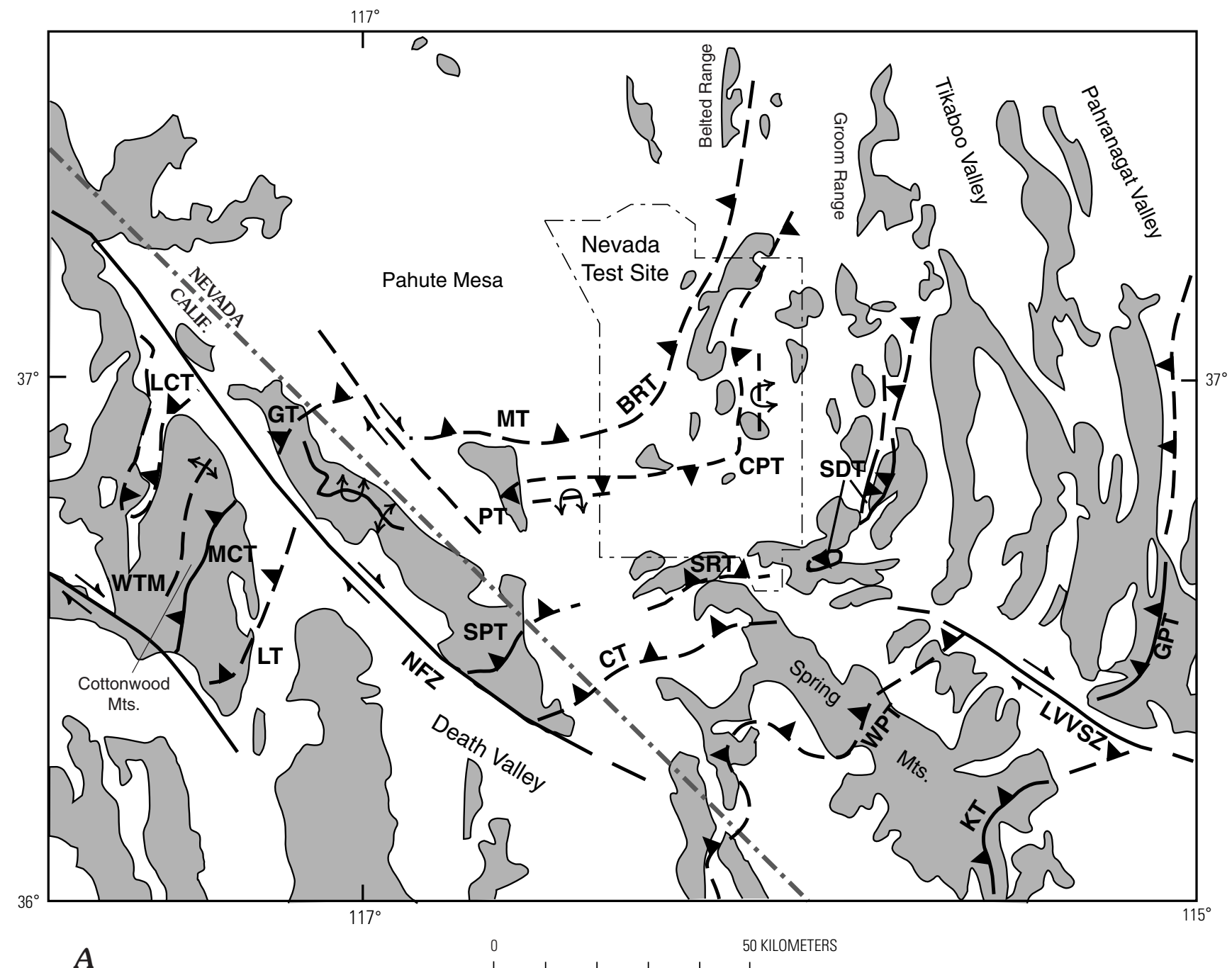

EXPLANATION

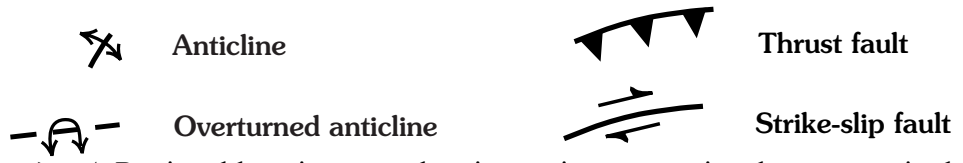

Figure 1 (above and facing page). A, Regional location map showing major contractional structures in the southern Great Basin around the Nevada Test Site. Geology in California based on Wernicke, Snow, and Walker (1988), Snow and Wernicke (1989) and Snow (1992). Mountain ranges indicated by shading. BRT, Belted Range thrust; CT, Clery thrust; CPT, CP thrust; GPT, Gass Peak thrust; GT, Grapevine thrust; KT, Keystone thrust; LT, Lemoigne thrust; LCT, Last Chance thrust; LVVSZ, Las Vegas Valley shear zone; MT, Meiklejohn thrust; MCT, Marble Canyon thrust; NFZ, Northern Furnace Creek fault zone; PT, Panama thrust; SDT, Spotted Range thrust; SPT, Shwaub Peak thrust; SRT, Specter Range thrust; WPT, Wheeler Pass thrust; WTM, Whitetop Mountain fold. B, Diagram showing areas covered by other figures in this paper.

\section{INTRODUCTION}

Although the Nevada Test Site lies across regionally significant stratigraphic boundaries and structural features (fig. 1), the area has not received the level of scientific investigation similar to other parts of the Great Basin because public access has been restricted since before World War II. Significant stratigraphic variations occur across a line through the Nevada Test Site; this line separates western facies, deposited on a marine slope in generally deeper water, from eastern facies, deposited on the continental shelf in generally shallower water. The facies contrast is seen throughout the stratigraphic column, but particularly in Silurian through Mississippian rocks. Major contractional structures at the Nevada Test Site include a complex system of foreland-vergent thrusts and folds and a younger belt of hinterland-vergent folds and local thrust faults. These contractional structures are generally parallel to preexisting stratigraphic trends. 


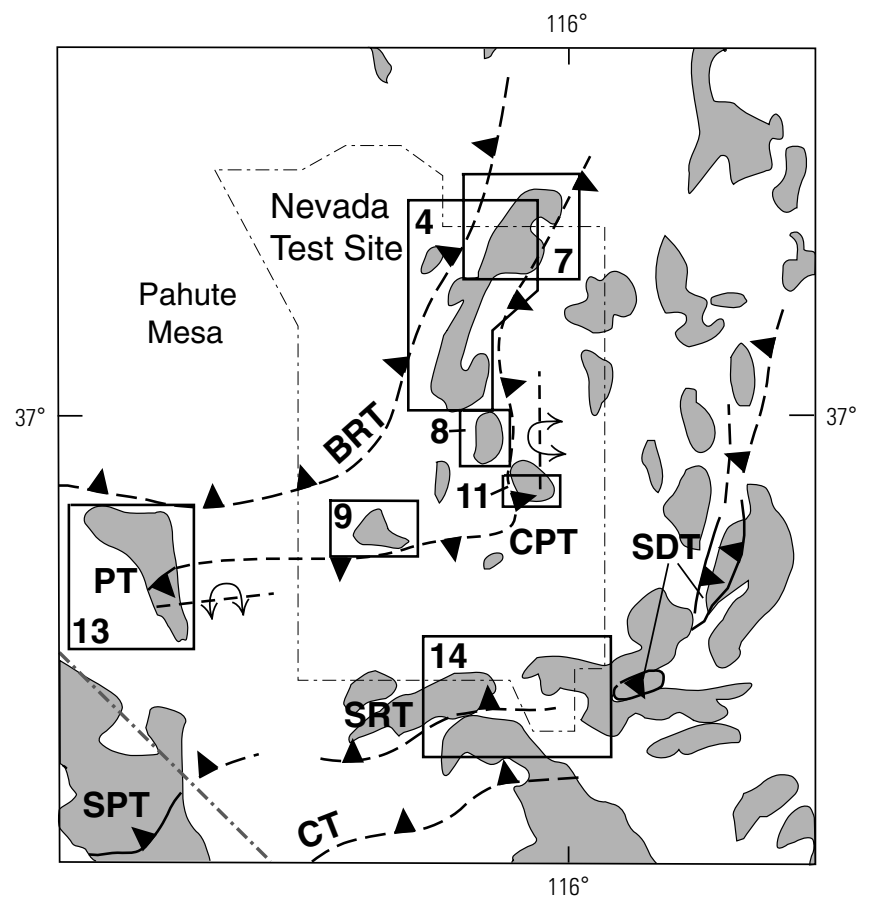

B

50 KILOMETERS

Paleozoic rocks at the Nevada Test Site were first described in moderate detail during reconnaissance regional geologic mapping (Johnson and Hibbard, 1957). This work produced good basic geologic maps but left many regional structural and stratigraphic questions unresolved. The upper Paleozoic stratigraphic terminology used at the Nevada Test Site (e.g., Johnson and Hibbard, 1957; Poole and others, 1961) differed from that used throughout much of the Great Basin (including the Pahranagat Range, the nearest Paleozoic exposures to the northeast; Reso, 1963; Jayko, 1990). The paleogeographic significance of these different stratigraphies was unknown. All low-angle faults were originally mapped as thrust faults, although Ekren and others (1971) showed that substantial normal displacement on low-angle faults had occurred in lower Paleozoic strata just north of the Nevada Test Site. More recent work has led to wider recognition of low-angle extensional faulting in the region (e.g., Guth and others, 1988; Cole and others, 1989, 1993; Hudson and Cole, 1993) and has shown the need to reevaluate the kinematics of all low-angle faults. Most of the thrusts were initially attributed to a single, east-vergent system (Barnes and Poole, 1968; Carr, 1974). McKeown and others (1976) indicated contrary vergence in cross sections for the CP Hills in the central Nevada Test Site, and Caskey (1991) confirmed that the structures there resulted from northwest-verging deformation. Various regional structural compilations had proposed different correlations of the major foreland- and hinterlandvergent structures through the region (e.g., Wernicke, Snow, and Walker, 1988; Caskey and Schweickert, 1992). These contrasting correlations were largely based on interpretations of map relationships for large parts of the Nevada Test Site, rather than on field observations, and the differences could not be resolved with data available through the mid-1990's.

Our studies of structures in the Paleozoic rocks at the Nevada Test Site have been motivated by the need to understand the regional controls on ground-water flow. The thick section of Middle Cambrian to Devonian limestone and dolomite is the major carbonate-rock aquifer of southern Nevada (Winograd and Thordarson, 1975; Dettinger, 1989). This aquifer transmits large volumes of ground water from the Nevada Test Site toward discharge areas in the Amargosa Desert and Death Valley (Laczniak and others, 1996). The pre-Middle Cambrian and Mississippian siliciclastic sections together serve to impede ground-water flow and to direct flow into the carbonate aquifer. Structures that alter the original stratigraphic framework of the carbonate aquifer, or those that produce additional fracture porosity through fault zones, have direct impacts on the movement of ground water through the region.

This paper summarizes our new understanding of the regional structural relationships at the Nevada Test Site. After brief summaries of the regional stratigraphy and structure, we describe the field relationships and kinematic analyses on which our structural interpretations are based. These observations are organized first by deformational event and, within these groups, by geographic locality. The older, forelandverging fold and thrust deformation is described first, followed by the hinterland-verging deformation and sinistral faulting. We then summarize the deformation history in the region and discuss regional correlations of the major structures. We conclude with some regional implications of our structural interpretations. The reader is referred to Trexler and others (1996) and Trexler and Cashman (1997) for the stratigraphy, biostratigraphy, and regional stratigraphic correlations used in this paper and for references to prior stratigraphic work.

Our principal conclusions are: (1) the regional forelandvergent thrust structure involves considerable replication of the section by irregular footwall duplex faults; (2) a broad zone of slightly younger contractional deformation has folded and faulted the earlier thrusts throughout the Nevada Test Site region with opposing vergence in the direction of the hinterland; (3) sinistral strike-slip faults with significant displacement are identified in the northern Nevada Test Site and beyond; and (4) pre-volcanic (pre-Oligocene) extensional deformation on low-angle normal faults has locally displaced the older structures. The resulting complicated three-dimensional distribution of Paleozoic rock units is difficult to extrapolate to depth or beneath areas of Neogene cover. The results reported below demonstrate that the regional carbonate aquifer in the Nevada Test Site vicinity is broken and displaced by thrust faults. In addition, it is highly likely that the Mississippian clastic confining unit is not an effective regional ground-water barrier because folding and faulting limit its lateral extent. 


\section{ACKNOWLEDGMENTS}

Our work has been done collaboratively with, and benefited greatly from, studies by many colleagues. These studies include stratigraphy of pre-Tertiary strata by Jim Trexler of the University of Nevada-Reno; Tertiary structure and stratigraphy by Mark Hudson, Scott Minor, and David Sawyer of the U.S. Geological Survey (USGS); paleontology by Anita Harris and Betty Skipp of the USGS, Mira Kurka of the University of Nevada-Reno, and Alan Titus of Washington State University; and hydrology by Randy Laczniak of the USGS. The interpretations in this paper are ours and are not necessarily shared by these collaborators. The U.S. Department of Energy funded Cole's investigations through Interagency Agreement DE-AI08-96NV11967 and predecessor agreements. Cashman's research was funded primarily by grants from the Nevada Nuclear Waste Projects Office through the Center for Neotectonic Studies at the University of Nevada-Reno. Some of her field work has also been supported by the USGS.

\section{STRATIGRAPHIC OVERVIEW}

The miogeoclinal sedimentary rocks of the Nevada Test Site vicinity record passive margin deposition from Late Proterozoic to Middle Devonian time. The lower part of this miogeoclinal sequence consists of at least 3,100 m of quartzite, arkosic sand, and micaceous shale of Late Proterozoic through Middle Cambrian age. These rocks are overlain by about 4,100 $\mathrm{m}$ of dolomite and limestone of Middle Cambrian to Middle Devonian age (fig. 2).

Sediments deposited between Late Devonian and Late Mississippian time in the Nevada Test Site region are synorogenic. They reflect the changed tectonic setting of the western margin of North America when oceanic rocks were emplaced eastward over the miogeoclinal sequence during the Antler orogeny. These synorogenic rocks record spatially and temporally variable depositional environments. Trexler and others (1996) documented three distinct and coeval sedimentary assemblages that were deposited from Late Devonian through Mississippian time in this area: (1) turbidites and debris-flow deposits about 1,800 $\mathrm{m}$ thick accumulated in a submarine trough on the west; (2) uniform mudrock at least 1,200 m thick was deposited in an adjoining muddy shelf environment to the east; and (3) carbonate mud, coral-reef complexes, and channel-sand deposits less than $350 \mathrm{~m}$ thick were laid down in a carbonate-bank environment farther to the east and south.

Latest Mississippian and Lower Permian rocks at the Nevada Test Site record shallow marine deposition. Latest Mississippian rocks are shallow-water channel sands deposited in a tidal mudflat environment that persisted into Early Pennsylvanian time. Regional emergence and erosion was followed by renewed submergence and carbonate deposition in the latter part of the Morrowan Provincial Series (late Early
Pennsylvanian; Titus, 1992). Pennsylvanian and Lower Permian strata (V. Davidov, Boise State Univ:, written commun., 1998) of the Tippipah Limestone are preserved in only two localities on the Nevada Test Site where they rest disconformably on the muddy shelf deposits of the Lower Pennsylvanian upper Chainman Shale and Scotty Wash Quartzite. No younger sedimentary rocks are preserved in the Nevada Test Site vicinity, and it is unlikely that Upper Permian or Mesozoic strata were ever deposited in this area (Stewart, 1980a).

Sedimentary rocks of these Paleozoic passive-margin and convergent-margin sequences show systematic changes in thickness and depositional environment across the region. In general, strata deposited toward the east and south document shallower water settings on the more stable continental shelf. Strata deposited more toward the north and west reflect the less stable and deeper water conditions of the continental slope. This contrast between western and eastern sections is observed throughout the stratigraphic column. Upper Proterozoic and Lower Cambrian siliciclastic sediments thicken markedly to the west-northwest (Stewart, 1980a). The Ordovician System thins progressively westward across the Nevada Test Site and passes westward from shelf depositional environments to deeper water carbonate deposits farther west. Both Silurian and Devonian carbonate strata change facies from rather massive shelf-environment dolomites on the east to thinner bedded limestone, dolomite, and debris-flow breccias toward the west (Stewart, 1980a; Trexler and others, 1996; Wahl and others, 1997).

\section{STRUCTURAL OVERVIEW}

The conceptual model of pre-Cenozoic structure in the Nevada Test Site through the middle 1980's consisted of a single major thrust that emplaced Upper Proterozoic rocks over folded Mississippian-Pennsylvanian strata (Barnes, Hinrichs, and others, 1963; Barnes and Poole, 1968; Carr, 1974, 1984). This structure was called the CP thrust and was depicted in maps and cross sections to be folded and faulted to various structural levels between the Eleana Range on the northwest and the Spotted Range on the southeast (see fig. 23 in Carr, 1984). A secondary thrust, conceptually modeled as a duplex of the CP thrust system and called the Mine Mountain thrust, was thought to place Devonian carbonate rocks on the same folded Mississippian footwall section. The model portrayed the $\mathrm{CP}$ thrust as parallel to bedding in both hanging wall and footwall (that is, a " hanging-wall flat" in the Upper Proterozoic Wood Canyon Formation overlying a "footwall flat" in the Upper Mississippian rocks; Carr, 1984).

Our work, including detailed geologic mapping, kinematic analyses, and stratigraphic studies with detailed biostratigraphic control, shows convincingly that the earlier conceptual model cannot explain the geology as now known. The presence of both foreland- and hinterland-vergent structures precludes the folded thrust model, which requires all 


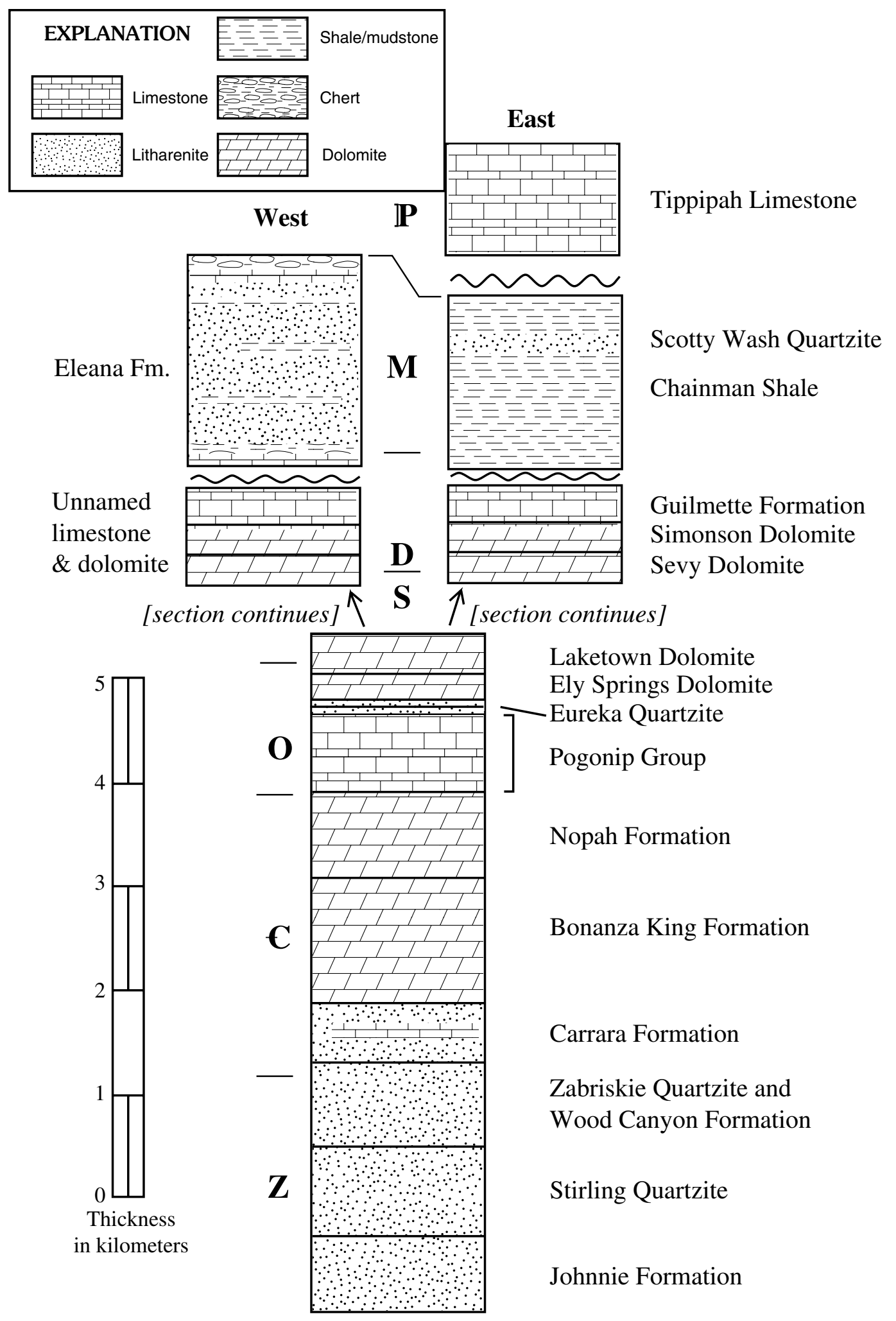

Figure 2. Stratigraphic column for pre-Tertiary rocks in the Nevada Test Site region. Nomenclature and average thickness values for Devonian and older units is based on the eastern, shallow-water facies. Western-facies Silurian and Devonian rocks are either unnamed, informally named (see Monsen and others, 1992; Cole and Cashman, 1998), or locally correlated with the Lone Mountain Dolomite or the Roberts Mountain Formation. Mississippian limestone units in the Spotted Range are locally named (Barnes and others, 1982). 
vergence toward the foreland, regardless of dip direction (Cole, 1997). The folded thrust model also implies that all hanging-wall rocks were derived from locations west of the entire footwall block. This predicted relationship is contradicted, for example, in northeastern Yucca Flat. Barnes and Poole (1968) interpreted the lower Paleozoic rocks in the Halfpint Range to comprise the "hanging wall" that was carried eastward over the younger "footwall" of the Eleana Range. However, Cambrian and Ordovician strata in the Halfpint Range have the lithic characteristics of the shallower water eastern-facies assemblage relative to the western-facies aspect of the Devonian and Mississippian rocks of the Eleana Range (Trexler and others, 1996).

New conodont alteration index (CAI) data place additional constraints on pre-Tertiary structure in the Nevada Test Site area. Data obtained since 1988 include both surface samples (e.g., Cashman and Trexler, 1994) and more than a dozen determinations on specimens from drill holes that penetrated carbonate rock beneath Cenozoic fill in Yucca Flat (Grow and others, 1994; A. Harris, written commun., 1991-1995; Cole, 1997; Cole and others, 1997). These results show that a northeast-trending belt of Ordovician through Pennsylvanian rocks between central Yucca Flat and the Calico Hills has never been exposed to thermal conditions in excess of about $150^{\circ} \mathrm{C}$, corresponding to a prolonged burial depth of less than $3 \mathrm{~km}$ (Epstein and others, 1977; Barker, 1994). The thermal history and structural position of these rocks, which are structurally beneath and bounded by two oppositely verging thrusts, led Trexler and others (1996) to conclude that this belt of low-temperature rocks was never tectonically buried by any thrust.

The pre-Tertiary structure of the Nevada Test Site region, based on these new data, includes both foreland- and hinterland-vergent folding and thrusting (fig. 3). The main features are (1) a principal foreland-vergent thrust (the Belted Range thrust, named following Caskey and Schweickert, 1992), (2) an extensive zone of duplex thrusting in the Belted Range footwall, and (3) a parallel zone of hinterlandvergent folding and thrusting to the east (the CP thrust system, as redefined by Caskey and Schweickert, 1992; and elaborated on by Cole and others, 1994; Trexler and others, 1996). In the southern Nevada Test Site region, additional foreland-vergent thrusts have been mapped in the northern Specter Range and in the Spotted Range, located generally along strike to the east. The Specter Range thrust was formerly correlated with the Spotted Range thrust (Barnes and Poole, 1968), but we believe it must die out west of the Spotted Range beneath Mercury Valley, as discussed in a following section. The Spotted Range thrust, as redefined in this paper, is only preserved in the Mercury klippe (Barnes and others, 1982) and along strike to the northeast in the Ranger Mountains (Longwell and others, 1965; Tschanz and Pampeyan, 1970; Guth, 1990). The source of the Mercury klippe remains an enigma.
Delineation of the fold and thrust structure described in this report was only possible because of the recent detailed stratigraphic, sedimentological, and paleontological work in the Devonian and Mississippian Systems, summarized in Cashman and Trexler (1994), Cole and others (1994), and Trexler and others (1996). The complexity of the structure only began to form recognizable patterns when we had established the original paleogeographic distribution of the Devonian-Mississippian depositional facies. Relevant information was recognized by the geologists who mapped the region in the 1960 's but was not sufficiently established to be incorporated in early maps and reports. The current compilation of regional pre-Tertiary geology (Cole, 1997) shows the distribution of eastern and western facies of the Devonian carbonates as well as three recognized facies of the Upper Devonian to Mississippian clastic rocks, on which the present structural interpretation is founded.

The foreland-vergent thrusts in the Nevada Test Site region are moderately inclined, ramp-dominated faults that form stacked duplex structures of limited lateral extent. These duplexes commonly juxtapose rock units that are similar in age, but they invariably carry a more western facies assemblage eastward over a more eastern facies assemblage. Folding associated with these thrusts is highly variable in scale and intensity and is controlled both by structural position and by lithology.

The hinterland-vergent deformation of the $\mathrm{CP}$ thrust system is demonstrably younger than the foreland-vergent Belted Range structures in the Nevada Test Site region. The hinterland-vergent system is much more widespread than previously recognized and is characterized by both folding and thrusting along its entire length on the Nevada Test Site. The hinterland-vergent deformation is chiefly expressed as bands of kinks and folds that overprint the foreland-vergent plates. Hinterland-vergent thrust faults are less commonly exposed, but their location can be inferred from age relationships and overturning in subsurface sections. Stratigraphic separation across these faults is pronounced and overturning is common, particularly in the footwall.

Map relationships in the northeastern Nevada Test Site indicate that contractional features have been repositioned along a series of sinistral faults that generally trend northsouth. Although total offset is unknown, minimum displacements of several kilometers are inferred across each of at least six faults. The sinistral faulting is commonly associated with evidence for east-west shortening across the fault. Field relationships indicate that the sinistral faulting postdates (or is possibly synchronous with) the hinterland-vergent folding and thrusting. We have found sinistral faulting at several locations in the Eleana Range and in the Oak Spring Wash area at the northern edge of the Nevada Test Site.

The timing of the complex contractional deformation in the Nevada Test Site area is poorly constrained. The only direct evidence is that the deformation postdates Lower Permian strata (which are involved in the deformation), and 


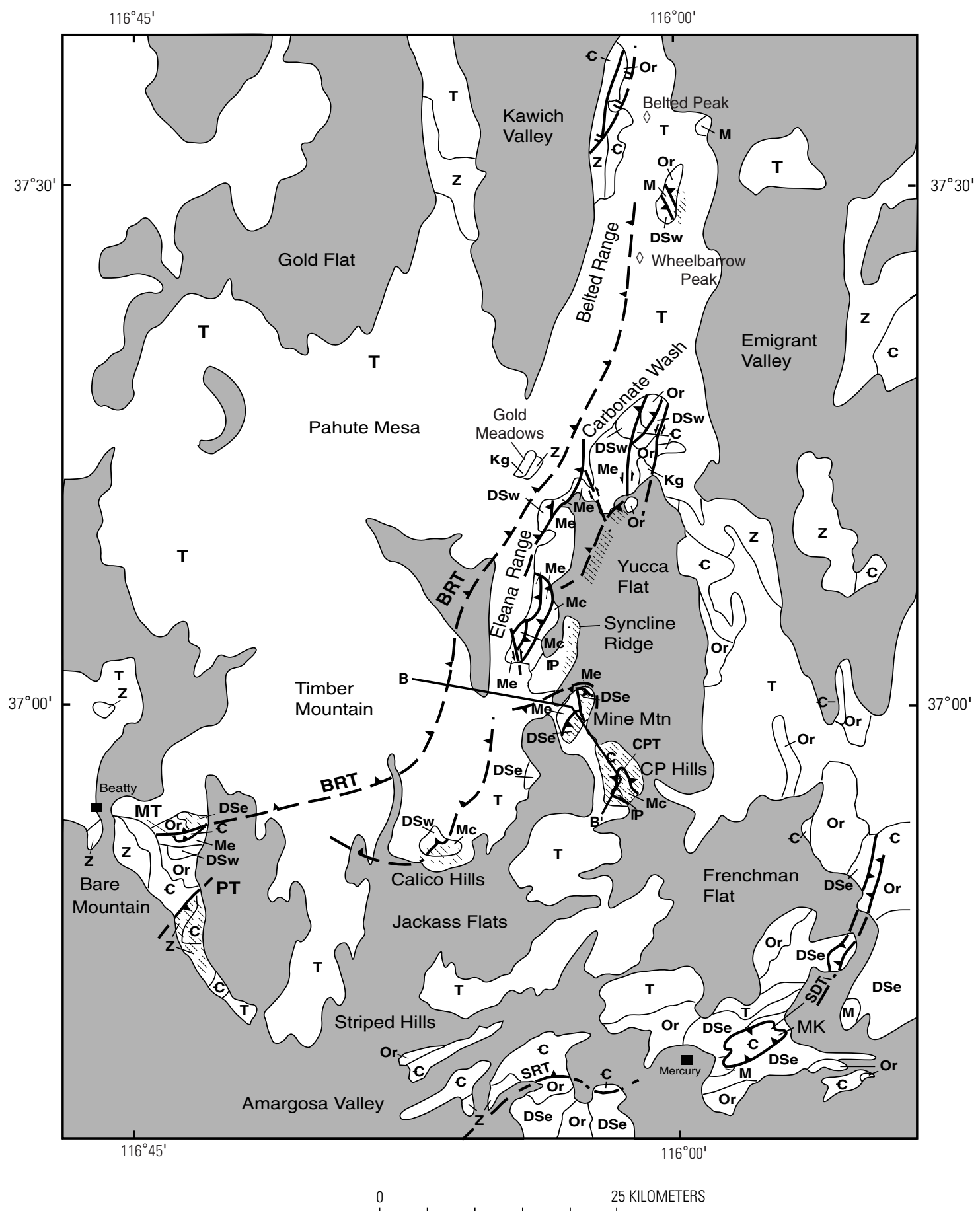

Figure 3. Structural summary map of the major contractional features in Paleozoic rocks in the Nevada Test Site vicinity. Ruled-pattern overprint indicates areas of hinterland-vergent deformation discussed as the CP thrust system. T, Tertiary deposits; Kg, Cretaceous granite; $\mathbb{P}$, Pennsylvanian; Me, Eleana Formation; Mc, Chainman Shale; M, Mississippian units in Spotted Range; DSe, eastern-facies Devonian-Silurian; DSw, western-facies Devonian-Silurian; Or, Ordovician; C, Cambrian; Z, Late Proterozoic; BRT, Belted Range thrust; CPT, CP thrust; MK, Mercury klippe; SDT, Spotted Range thrust; SRT, Specter Range thrust; other thrust faults labeled as on fig. 1. Fault with double hachures in northern Belted Range is a conspicuous pre-Oligocene extensional fault (Ekren and others, 1971). Section line B-B' is shown schematically on fig. $4 C$. 
predates Late Cretaceous (ca. $100 \mathrm{Ma}$ ) granites and mafic dikes, which intrude some of the thrusts (Houser and Poole, 1960; Naeser and Maldonado, 1981; Cole and others, 1993). Proposed correlations of these structures toward the west (Wernicke, Snow, and Walker, 1988; Snow and Wernicke, 1989) would imply pre-Middle Triassic (probably Late Permian) shortening, based on cross-cutting intrusive rocks in the Cottonwood Mountains (Snow, 1992). Earlier workers assumed the deformation in the Nevada Test Site region was Cretaceous, because the thrusts are similar in overall trend to the well-documented Cretaceous (Sevier) deformation in the Keystone-Muddy Mountains-Glendale thrust systems farther south and east (Armstrong, 1968; Fleck, 1970). However, this Sevier deformation involves rocks younger than 96 Ma (Fleck, 1970; Bohannon, 1992), whereas the Test Site deformation is intruded by rocks as old as $102 \mathrm{Ma}$ (Cole and others, 1993). Recent studies of the Central Nevada thrust belt, which lies on strike northeast of the Test Site, show that the contraction there is earlier than Early Cretaceous (Taylor and others, 1993).

Structural and stratigraphic trends in the Precambrian and Paleozoic rocks show a progressive 90-degree change in orientation (termed an "oroflex" by Albers, 1967) in the region of southern Nevada surrounding the Nevada Test Site (fig. 1). The general traces of both foreland- and hinterlandvergent contractional structures trend nearly east-west at Bare Mountain on the west; they trend northeasterly in the Spotted Range; and they trend almost north-south in the Belted Range in the north. This oroflexural bend has been interpreted to have formed in conjunction with dextral strikeslip offset on the Las Vegas Valley shear zone (Burchfiel, 1965; Guth, 1981; Wernicke and others, 1983; Wernicke, Axen, and Snow, 1988). However, we conclude later in this paper that most of the oroflexural bending is much older and that it likely formed during the contractional deformation.

The first episode of extensional faulting in the Nevada Test Site region was characterized by low-angle normal faults that accommodated locally significant extension in the Paleozoic rocks (Cole and others, 1989, 1993, 1994; Hudson and Cole, 1993; Cole, 1997). This deformation predates the oldest volcanic rocks wherever it has been studied; it is premiddle Miocene in the Yucca Flat area (Cole and others, 1989 ) and pre-Oligocene in the Belted Range (Ekren and others, 1967, 1971). Strong circumstantial evidence indicates that similar extensional fault complexes in northwestern Yucca Flat are intruded by dikes dated at $102 \mathrm{Ma}$ (Cole and others, 1993). Low-angle extensional faults also occur over a broad area to the east, where they are overlapped by middle Oligocene volcanic rocks (Jayko, 1990). Such local evidence does not support any conclusion regarding synchronous regional extension events because the time of actual deformation is not defined by such cross-cutting relations. We believe individual, local extension events are likely based on the strongly domainal nature of extension in the southern
Great Basin (Stewart, 1980b; Cole, 1987; Guth and others, 1988; Hamilton, 1988; Jayko, 1990).

The second extension event in the Nevada Test Site area occurred during and following the eruptive cycle of the southwestern Nevada volcanic field (generally 15 to $9 \mathrm{Ma}$; Sawyer and others, 1994). This event is characterized by block tilting, alluvial basin subsidence, and relatively minor lateral displacement of Paleozoic rocks (Barnes, Hinrichs, and others, 1963; Carr, 1974, 1984; Cole, 1997). For much of the area considered in this paper, including the Belted Range, Yucca Flat, the Halfpint Range, and Calico Hills, this extension is quite minor. In addition, paleomagnetic data demonstrate these rocks have experienced essentially no vertical-axis rotations (Hudson, 1992; Hudson and others, 1994). For these reasons, structures related to Miocene and younger extension will not be described in this paper except where they have a significant influence on map relationships. Information about the younger deformation is available in several recent reports (Carr, 1984, 1988; Hamilton, 1988; Hudson and others, 1994; Minor, 1995; Hudson, 1997).

The following sections describe the structures identified in the Nevada Test Site region and their directions of vergence. Local details of stratigraphy and thermal history (conodont CAI data) are presented as necessary to explain and support the structural interpretations. Stratigraphy, paleogeography, thermal history, and structure are intricately connected in the history of this area, and information about each discipline is beneficial to understanding the others.

\section{BELTED RANGE THRUST}

The principal contractional structure in the Nevada Test Site region carried Late Proterozoic and Cambrian Wood Canyon Formation toward the foreland over rocks as young as Late Mississippian. The implied stratigraphic throw is at least $7 \mathrm{~km}$ (fig. 2). This structure was originally designated the "CP thrust" by Barnes, Hinrichs, and others (1963) based on this structural transposition in the CP Hills area; however, we now know that the structure in the CP Hills verges oppositely, toward the hinterland. Caskey proposed the name "Belted Range thrust" be used to designate the main foreland-vergent structure and that the name CP thrust be redefined to denote the westward-vergent structures exemplified by the CP Hills (Caskey, 1991; Caskey and Schweickert, 1992). We adopt Caskey's terminology. The CP thrust system in the Nevada Test Site area is described more fully later in this paper.

The Belted Range thrust is best defined in the Rainier Mesa area northwest of Yucca Flat (fig. 3). The fault at the base of the upper plate is everywhere covered by Miocene volcanic rocks, but the location of the thrust is known within less than $100 \mathrm{~m}$ on the basis of extensive drilling in this area for the underground nuclear testing program (Gibbons and 
others, 1963; Cole, 1997). Upper plate micaceous quartzites of the Wood Canyon Formation are exposed nearby to the west in the Gold Meadows area where they consistently dip $30^{\circ}-45^{\circ}$ westward. The rocks in the immediate footwall in this area are Lower Devonian slope-facies dolomite and dolomitic limestone (Cole and others, 1997), which also dip moderately west. These Devonian carbonates are interpreted to form a narrow horse block that was sliced off the thrust footwall somewhere to the west (described below). The Belted Range thrust is inferred to share the orientation of rocks on either side because neither plate shows signs of local folding and because the trace of the thrust is parallel to the strike of beds in both plates (Cole and others, 1994; Cole, 1997).

The location of the Belted Range thrust in the central and northern Belted Range (about $40 \mathrm{~km}$ north of Yucca Flat) can be inferred from the distribution of Paleozoic rocks exposed in windows through the Miocene volcanic cover (fig. 3). Near Belted Peak, the Wood Canyon Formation, Zabriskie Quartzite, and Cambrian limestone form an eastdipping panel that becomes progressively overturned toward the east, farther to the north (Ekren and others, 1967, 1971; Sargent and Orkild, 1973; Cole, 1997). The unnamed Cambrian limestone section in the Belted Range plate is ageequivalent to the Bonanza King Formation but represents western-facies strata deposited below the shelf edge in deeper water (A.R. Palmer, Institute for Cambrian Studies, written commun., 1994). This overturning and the eastward dip are consistent with a fault-propagation anticline in the hanging wall that may have formed as the thrust cut upsection northward into younger formations. The amount of lateral displacement on the Belted Range thrust cannot be estimated from present data, but the preservation of this hanging-wall anticline suggests that the offset there may be less than it is farther south.

The footwall of the Belted Range thrust southeast of Belted Peak is discontinuously exposed (fig. 3), but contains post-Lower Mississippian (post-Kinderhookian) debris-flow limestone breccia, siliceous siltstone, and chert-pebble conglomerate that are correlative with the Eleana Formation (Ekren and others, 1967, 1971; A.G. Harris, written commun., 1993). The Eleana-equivalent beds are upright, dip westward, and appear unfolded at this location. About $8 \mathrm{~km}$ south of Belted Peak and $4 \mathrm{~km}$ northeast of Wheelbarrow Peak, red siltstone and chert-lithic sandstone of the Eleana are preserved in a narrow fault sliver between upper Lower Devonian dolomite on the west and Upper Cambrian and Ordovician rocks to the east (Ekren and others, 1971; Sargent and Orkild, 1973; A.G. Harris, written commun., 1994). The Devonian dolomite and the Cambrian rocks both show lithic characteristics similar to eastern-facies shallow-water sections. We infer from this relationship that these blocks were emplaced over the Eleana Formation from the east, following Belted Range thrusting.
A major foreland-vergent thrust, mapped by Monsen and others (1992) east of Beatty, Nev. (fig. 3; located about $60 \mathrm{~km}$ southwest of the Yucca Flat area) is interpreted to be the Belted Range thrust. Due to the regional oroclinal flexure, this thrust generally strikes east-northeast, dips northward at $40^{\circ}-50^{\circ}$, and verges toward the southeast (Monsen and others, 1992). The lowest beds in the hanging wall are Lower Cambrian Zabriskie Quartzite and western-facies beds of the Carrara Formation (Palmer and Halley, 1979) that dip northward at about the same inclination as the thrust. The footwall in this area consists of north-dipping beds equivalent to the Eleana Formation that are as young as Late Mississippian immediately beneath the thrust (Trexler and others, 1996). The general absence of small-scale folding in the fine-grained beds of the Eleana in the footwall and the overall similarity in attitude of beds in the hanging wall and the footwall suggest the Belted Range thrust is flat-on-flat in this location.

In summary, the Belted Range thrust is a regional feature that can be traced or inferred over a strike length of more than $130 \mathrm{~km}$ from the Bare Mountain area in the southwest to the northern Belted Range. The thrust plate is generally simple and displays little folding or internal disruption. Along its length, it typically places Upper Proterozoic Wood Canyon Formation over the DevonianMississippian Eleana Formation, but footwall horse blocks locally intervene. The nominal stratigraphic throw on the thrust is on the order of $7 \mathrm{~km}$. The fault generally dips at moderate inclination toward the hinterland, as do beds in the hanging wall. Local deformation along the thrust is not generally noted, but a hanging-wall anticline appears to have formed in the central and northern Belted Range in response to the thrust cutting upsection through the hanging wall.

The Belted Range thrust has been correlated with the Grapevine thrust northwest of Beatty (fig. 1) and, farther west in the Cottonwood Mountains, with the Last Chance thrust northwest of Death Valley (Snow and Wernicke, 1989; Snow, 1992). The correlation is based on stratigraphic juxtaposition of Upper Proterozoic on Mississippian sections, the local presence of hanging-wall ramps, and regional structural position. As will be described next, complex zones of footwall duplexing are common to the Belted Range thrust in the Nevada Test Site area and to the Last Chance thrust in the Cottonwood Mountains (Racetrack duplex zone of Snow, 1992).

\section{DUPLEX STRUCTURES IN THE BELTED RANGE FOOTWALL}

The footwall block of the Belted Range thrust in the Nevada Test Site area displays significant folding and stratigraphic slicing on numerous foreland-vergent structures. Large overturned folds involve parts of the section as 
old as Late Cambrian, and fault-bounded horse blocks of diverse parts of the section are juxtaposed against other blocks of various ages. Although it is difficult to generalize, the stacked duplex blocks in many locations display a general order in that the higher block carries rocks of more western facies aspect, and the apparent amount of stratigraphic throw generally decreases upward. The sense of tectonic transport is nonetheless consistently toward the foreland.

Folds and faults within this footwall duplex have limited lateral extent and appear to be structural discontinuities of less than a few tens of square kilometers in extent. As described below, discrete thrust faults can be traced along strike into folds whose limbs pass from steep to moderate attitudes. Folds in horse blocks show irregular plunge attitudes and steepen near the lateral edge of the horse where, most likely, the amount of throw in the faulted core of the fold diminishes rapidly. These lateral changes in structural geometry indicate that the overall contractional strain was accommodated on numerous, local-scale folds and faults that acted to move small parts of the footwall away from the advancing Belted Range roof thrust. The irregular nature of the strain and the modest scale of the folds and faults combine to produce seemingly incongruous structures in adjacent horse blocks; for example, folds that plunge toward each other, folds that differ in trend by tens of degrees, and out-of-sequence thrusts.

The Mississippian Chainman Shale and the overlying Pennsylvanian and Lower Permian Tippipah Limestone appear to have remained largely autochthonous with respect to all the structurally higher duplex structures that formed west and north of the Chainman (Belted Range duplexes are confined to the hinterland side of the Chainman; Cole, 1997). The physical nature of the Chainman Shale, comprising more than $1,200 \mathrm{~m}$ of uniformly thin-bedded shale and finegrained siltstone, is easily deformed in compression and may have accommodated the structural thickening and stratigraphic duplication in this duplex zone.

The footwall structures are described below in general geographic progression from northern Yucca Flat southwestward to Bare Mountain. The Eleana Range is described first because the most data are available in this area and because this range displays many of the kinds of features that can only be inferred elsewhere.

\section{ELEANA RANGE}

Structures in the Eleana Range (fig. 4) on the west side of Yucca Flat illustrate the style of deformation in the footwall of the Belted Range thrust. Most of these occur within the Eleana Formation and the time-equivalent, but structurally lower, Chainman Shale to the east. Both units present significant challenges for mapping structure, primarily because both are thick and uniform with few marker beds. Stratigraphic data and interpretations for both the Eleana
Formation and Chainman Shale, which were essential to deciphering the Eleana Range structure, are summarized in Trexler and others (1996) and Trexler and Cashman (1997).

The Dolomite Hill plate is the structurally highest of three allochthonous plates between the Belted Range thrust and the Chainman Shale in the central and southern Eleana Range (fig. 4). It consists of more than $600 \mathrm{~m}$ of Devonian and Upper Silurian dolomite that originated from a westernfacies depositional setting (A.G. Harris, written commun., 1993; Cole and others, 1997). These dolomites dip homoclinally westward and do not display much small-scale deformation in outcrop. Within a few meters of the contact with the underlying Eleana Formation, the dolomites are intensely shattered and silicified and locally display a faint platy fracture parallel to the fault surface. These mesoscopic structures may not be typical, however, because the present contact exposed in some localities is a planar, polished surface that records multiple (dominantly strike-slip) transport directions.

Drill hole ER-12-1, spudded in the Dolomite Hill plate (fig. 4A), revealed complex faulting at depth. It entered the Eleana Formation at about 300-m depth, which implies a dip of $25^{\circ}$ on the base of the Dolomite Hill plate westward from its mapped trace (Cole and others, 1993, 1994; Laczniak and others, 1996). However, the hole also penetrated a brecciated slice of Ordovician Antelope Valley Limestone within the Devonian dolomite, a brecciated slice of Upper Devonian dolomite within the Eleana Formation, and $300 \mathrm{~m}$ of Lower to Middle Devonian dolomite structurally beneath the Eleana at the bottom of this 3588-ft (1093-m) hole (Cole and others, 1993; Laczniak and others, 1996). It is therefore clear that the Dolomite Hill duplex horse is underlain by other fault slices that are not exposed at the surface. In addition, Cole and others (1993) present circumstantial evidence that postthrusting extension most likely rearranged pieces of the footwall thrust complex.

The next lower plate, designated the Grouse Canyon plate by Trexler and others (1996), includes most of the central Eleana Range (fig. 4) and consists entirely of chert-lithic conglomerate, sandstone, siltstone, and bioclastic limestone of the Eleana Formation. The overall structure of the Grouse Canyon plate is a large fault-bend fold. East of the ER-12-1 drill hole, several hundred meters of Eleana at the structural top of the Grouse Canyon plate is tightly folded into chevrons overturned toward the east (foreland). This folding passes eastward into an east-dipping homoclinal section, which is interpreted to be the frontal limb of a large fault-bend fold. This fold plunges moderately northward at the north end of the range and appears to die out in a lateral ramp where the range disappears beneath alluvium, south of Quartzite Ridge. Farther south in the Eleana Range, the west-dipping limb of the fault-bend fold is locally exposed beneath the Tertiary volcanic cover. In these locations, strongly brecciated fault slices of dolomite and dolomitic quartzite (base of the higher Dolomite Hill plate) are emplaced over and subparallel to the westdipping limb of the Grouse Canyon plate anticline. 


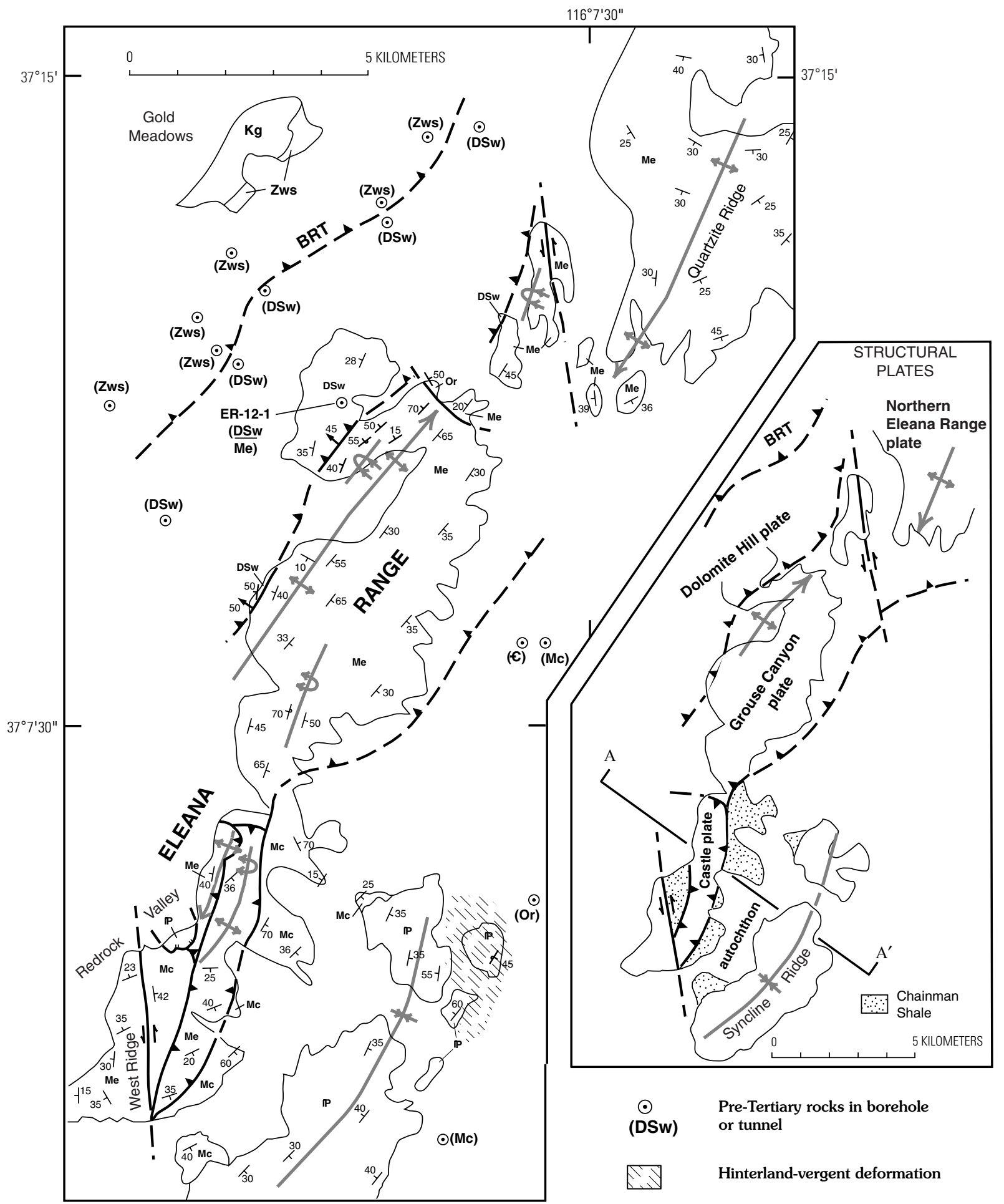

A

Figure 4 (above and following page). Geology of the Eleana Range (adapted from Cole, 1997, and unpub. mapping by P. Cashman). A, Geologic map of the Eleana Range and diagram showing principal thrust plates; stippled areas are underlain by parautochthonous Chainman Shale. $B$, Schematic cross section from the Eleana Range across Syncline Ridge along line A-A' (line of section shown in fig. $4 A$; adapted from Trexler and others, 1996). $C$, Schematic cross section from the Belted Range thrust, across Mine Mountain, to the CP Hills along line B-B' (line of section shown in fig. 3; adapted from Trexler and others, 1996). Abbreviations same as those on figs. 1 and 3. 


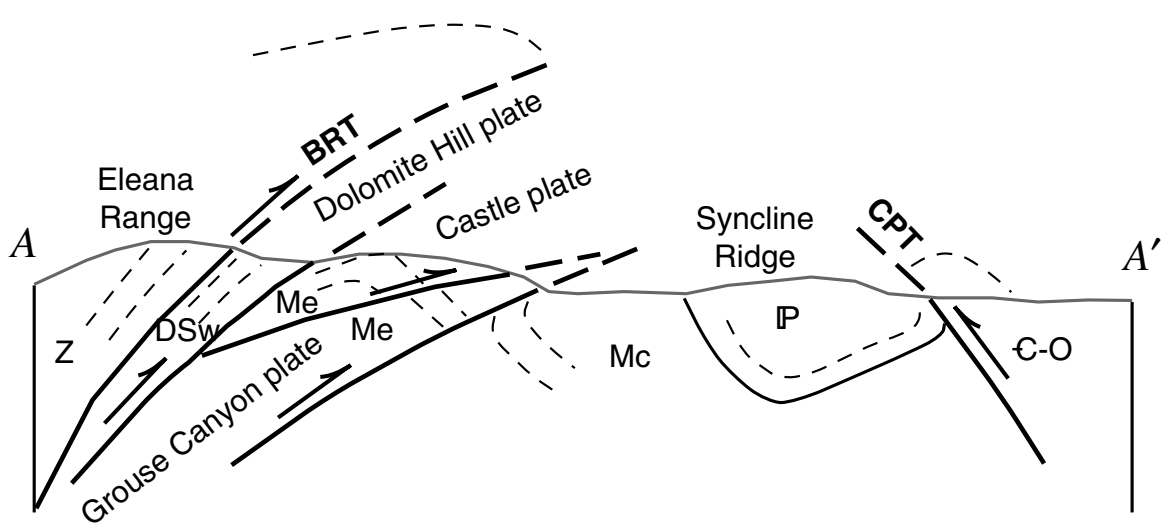

B

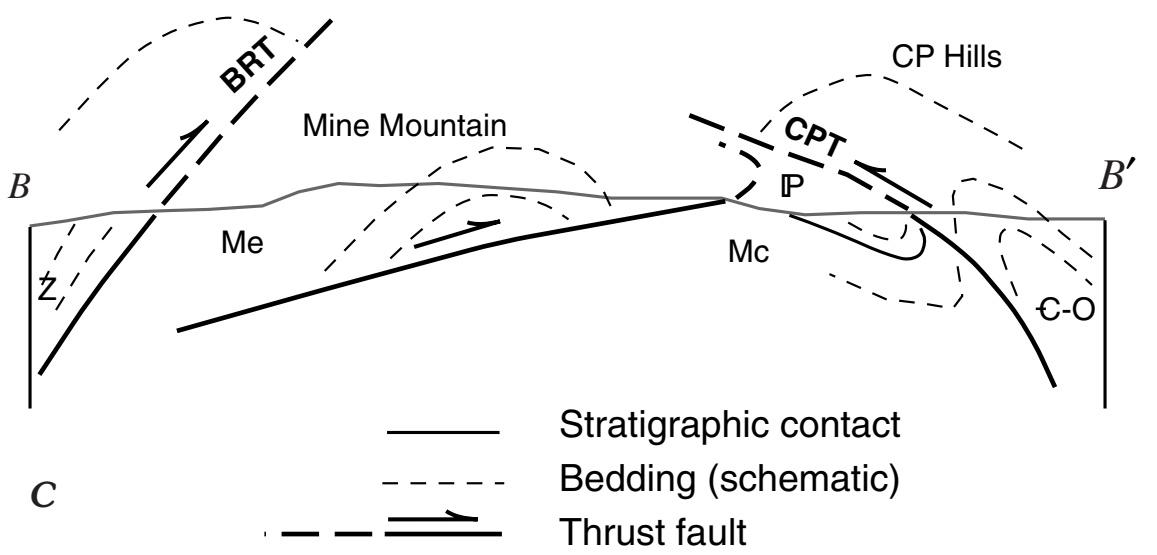

The Northern Eleana Range plate includes Quartzite Ridge and the Carbonate Wash area to the north (fig. 4). We identify this plate as a separate duplex horse beneath the Belted Range thrust even though it is nearly on strike with the Grouse Canyon plate and bears a similar east-verging anticline. Structural evidence indicates the two plates are separate: macroscopic and mesoscopic east-verging structures in the Northern Eleana Range plate plunge south (fig. $5 \mathrm{~A}$ ), whereas those in the Grouse Canyon plate plunge north (fig. $5 B$ ). Quartzite Ridge is a broad, south-southwest-plunging anticline composed entirely of Eleana Formation strata. This anticline plunges southward under the alluvial fill at the north end of Yucca Flat, probably into a lateral ramp similar to that at the north end of the Grouse Canyon plate.
In addition, we note several sedimentological differences between the Northern Eleana Range plate and the Grouse Canyon plate. The Eleana Formation at Quartzite Ridge is fine sandstone and bioturbated mudstone through most of the section that exceeds 1,300 $\mathrm{m}$ in thickness (Trexler and Cashman, 1997). It coarsens upward to include conglomerates and (notably) debris-flow pebbly mudstone beds immediately below Chesterian bioclastic limestones at the top of the exposed section. The Eleana Formation in the Grouse Canyon plate is characterized by more dramatic grain size differences (e.g., shale interbedded with coarse conglomerate) that suggest a higher energy depositional environment, probably the inner zone of a submarine fan complex (Cashman and Trexler, 1991, 1994; Trexler and Cashman, 1997). 
The present contact between the Grouse Canyon plate and the Northern Eleana Range plate is a north-northweststriking left-lateral fault (fig. 4) that postdates the east-vergent thrusting and folding. This fault juxtaposes steep to overturned, locally cleaved, rocks of the western edge of the Grouse Canyon plate on the west against gently dipping, uncleaved rocks of the Northern Eleana Range plate on the east. The left-lateral sense of motion on the fault is shown by drag folding of the rocks on its east side.

The Quartzite Ridge anticline is largely symmetrical and upright (fig. $5 \mathrm{~A}$ ), but its eastern edge is truncated by the Tippinip fault (fig. 6). Approaching the Tippinip fault, bedding in the southeast-dipping limb of the anticline strikes more northerly and steepens until it eventually overturns eastward at the fault contact with Ordovician rocks (Houser and Poole, 1960; Cole and others, 1997). This fault is separate from (and younger than) the thrust that places the Eleana over Chainman Shale along the southeastern flank of Quartzite Ridge (see below).

North of Quartzite Ridge along the trend of the Tippinip fault, Cambrian through Silurian rocks are folded into a northplunging, east-verging syncline (fig. 7) (Rogers and Noble, 1969). The western limb of this fold is overturned to dips as low as $55^{\circ}$. This structure is inferred to have formed by footwall shortening beneath the Belted Range thrust because its trend is parallel to the thrust and because the sense of overturning is consistent with Belted Range kinematics. Nevertheless, this overturned fold lies in an anomalous structural position, flanked by younger rocks on both sides (Rogers and Noble, 1969; Cole, 1997). These relationships indicate that the structures along the Tippinip fault result from multiple deformations, which are discussed more fully below.

Both the Grouse Canyon plate and the Quartzite Ridge anticline terminate to the east or southeast in thrust contacts with the Chainman Shale (Trexler and others, 1996; Cole, 1997; Cole and others, 1997). The thrust contact is locally preserved in the southern Eleana Range (fig. 4) where it is a subhorizontal surface, but younger high-angle faults offset the thrust at these locations and obscure its original orientation. The thrust is most commonly covered, but the presence of Chainman Shale beneath alluvial fans on the west side of Yucca Flat is confirmed by distinctive cuttings and by some fossil data from several drill holes that penetrate to the Paleozoic rocks in this area (Cole, 1997; Cole and others, 1997). The sense of vergence on this thrust is clearly toward the east, as displayed by asymmetry of hanging-wall anticlines, asymmetry in cascading fold trains in bioclastic limestone beds of the uppermost Eleana Formation, and by internal fault-propagation folds in the Grouse Canyon plate that produce eastward-overturned beds and local west-dipping cleavage.

The Eleana-Chainman contact was not originally recognized as a fault. The fault is poorly exposed, and both the Chainman Shale and the Eleana Formation generally dip toward the east along the east flank of the Eleana Range (Poole and others, 1961; Orkild, 1963; Barnes and Poole,
1968). Cashman and Trexler $(1991,1994)$ recognized that the Eleana and Chainman were two coeval Mississippian sections juxtaposed by a thrust. Additional confirmatory data on this relationship are presented in Trexler and others (1996) and Cole and others (1997). The Chainman Shale (roughly

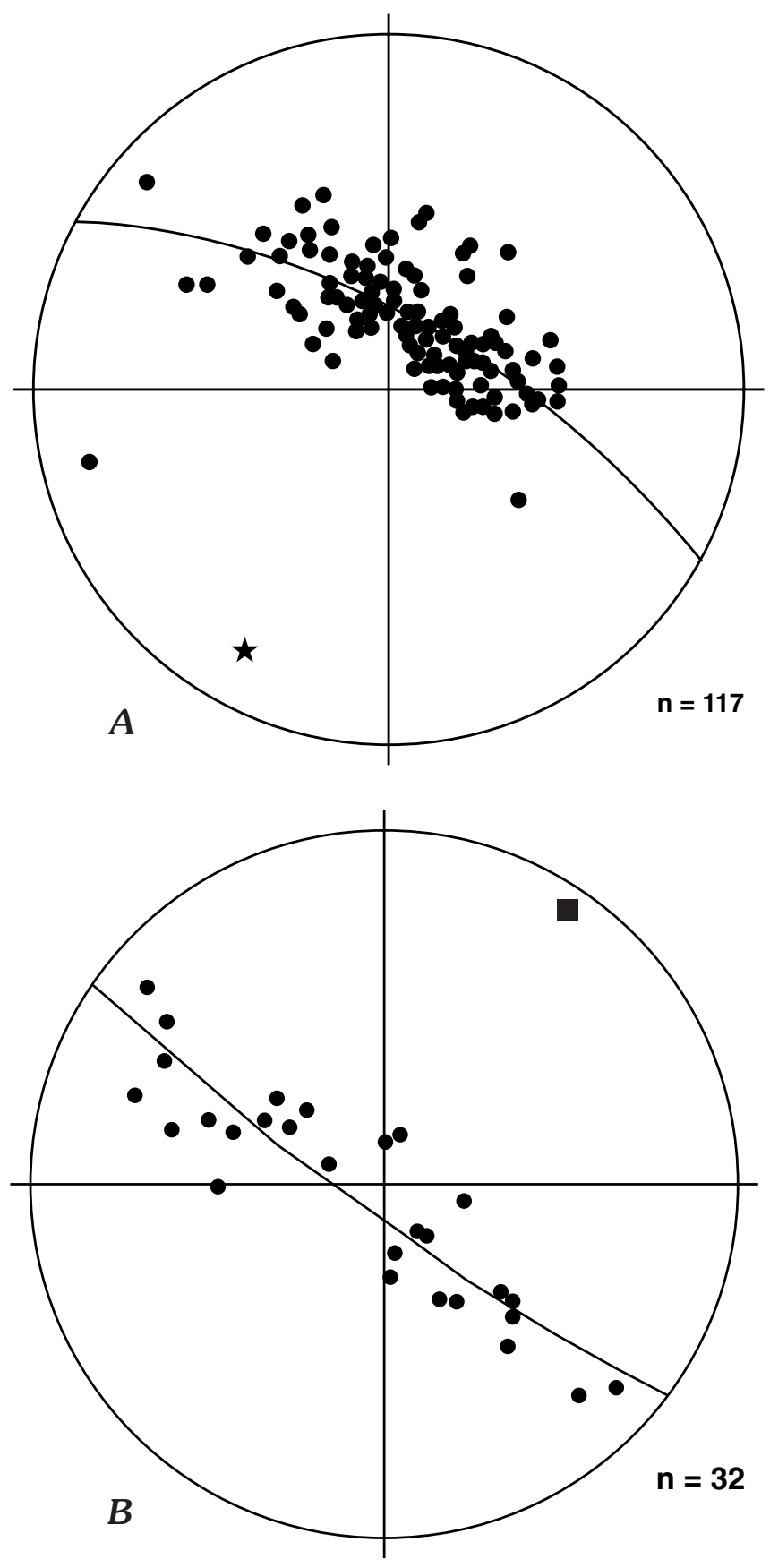

Figure 5. Structural data for the Eleana Range. $A$, Stereogram showing poles to bedding for the Quartzite Ridge anticline; pole (star) to statistical best-fit great-circle distribution for 117 poles to bedding shows that the fold plunges gently south-southwest. $B$, Stereogram showing poles to bedding for the northern Grouse Canyon plate; pole (square) to statistical best-fit great-circle distribution for 32 poles to bedding shows that the fold plunges gently north-northeast. 


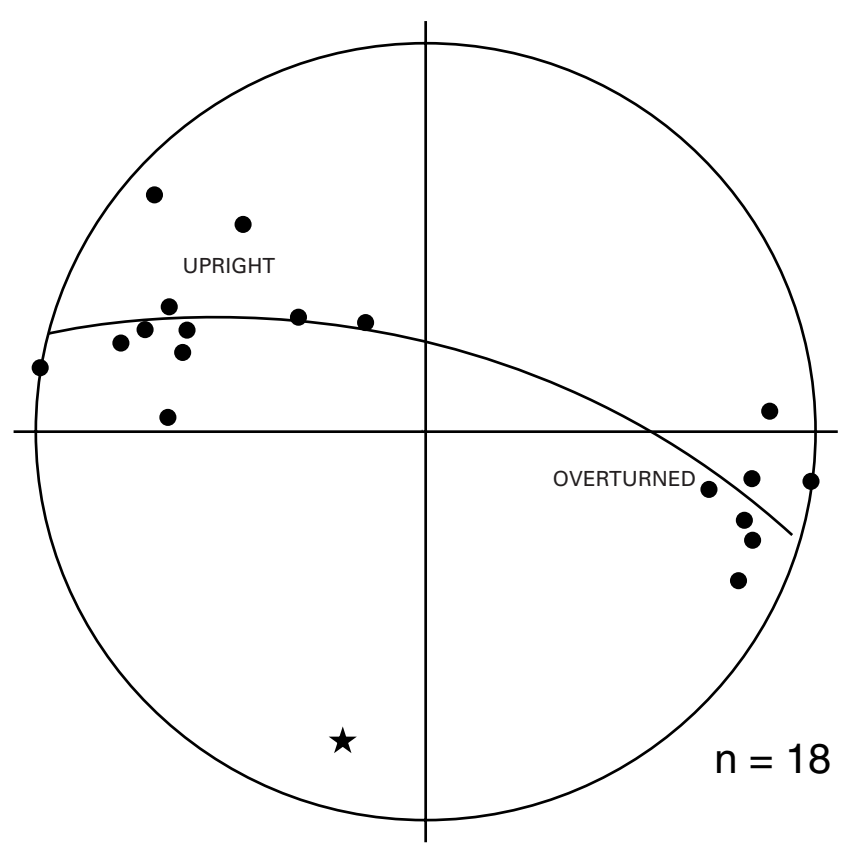

Figure 6. Stereogram showing poles to bedding for the overturned fold west of the Tippinip fault; pole (star) to statistical best-fit greatcircle distribution for 18 poles to bedding shows that the fold plunges gently south-southwest.

1,400 m thick) was continuously deposited from Early Mississippian (pre-Osagean) to Early Pennsylvanian time and largely consists of carbonaceous mudstone and very fine quartzose sand. In contrast, the Eleana Formation (roughly 2,000 m thick) was deposited from Late Devonian to Late Mississippian time in a different depositional setting characterized by submarine turbidite flows (Trexler and Cashman, 1997). The two formations also record contrasting thermal histories (see below). The dissimilarity of the two formations and their depositional histories argues that the thrust between them represents considerable lateral transport.

The small, structurally complex Castle plate overlies the Grouse Canyon plate in the southern Eleana Range (fig. 4). The exposed extent of the Castle plate is less than $4 \mathrm{~km}^{2}$, but it contains two conspicuous imbricated hanging-wall anticlines with their leading limbs overturned to the east. One of the hanging-wall anticlines plunges steeply at its south margin where it dies out in a lateral ramp. The Castle plate carries a distinctive Eleana Formation assemblage whose lithologic and sedimentological characteristics indicate deposition closer to the turbidite trough axis (that is, farther west) than the Eleana of the Grouse Canyon plate (Cashman and Trexler, 1991, 1994; Trexler and Cashman, 1997). The Castle plate locally projects eastward beyond the thrust front of the Grouse Canyon plate and rests directly on the Chainman Shale (fig. 4). This relationship suggests the Castle plate may have been emplaced later than the Grouse Canyon plate and documents out-of-sequence thrusting in the footwall of the Belted Range thrust.
Post-contractional extension is known from the southern Eleana Range, although its effects seem to be relatively minor. The west flank of the Castle plate (fig. 4), immediately below the Tertiary volcanic cover, exhibits top-to-thewest kinematic indicators on moderately west dipping surfaces. Similar structures underlie the volcanic rocks along the west edge of West Ridge (fig. 4), at the southern end of the Eleana Range. At the south margin of the Castle plate just east of Redrock Valley, several small outcrops of Pennsylvanian and Lower Permian Tippipah Limestone lie in fault contact on top of both the Chainman Shale and the Eleana Formation (Orkild, 1963; Cole, 1997). Kinematic indicators are absent here, but the silicified and brecciated bases of these limestone outcrops resemble deformation at other extensional faults in the area (Cole and others, 1989; Hudson and Cole, 1993) and differ from the deformation at thrust faults.

The only other exposed Pennsylvanian and Permian limestone in the area is located at Syncline Ridge, $4 \mathrm{~km}$ to the east of the southern Castle plate. Conodonts from the isolated blocks of Tippipah have low CAI values, like all those from Syncline Ridge, whereas conodonts from the underlying Eleana Formation have uniformly high CAI values (A.G. Harris, written commun., 1993; Grow and others, 1994). We conclude that the blocks of Tippipah Limestone were transported westward, counter to the dominant direction of thrusting in the southern Eleana Range. Several structurally isolated blocks of Eleana Formation and Tippipah Limestone form low hills at the southernmost end of the Eleana Range and Syncline Ridge. Bedding within these blocks is truncated against their subhorizontal bases, but kinematic indicators and well-developed slip surfaces are absent. In all cases, the rocks in these blocks closely resemble those in adjacent ridges and are interpreted to be locally derived.

\section{MINE MOUNTAIN-SHOSHONE MOUNTAIN AREA}

The complex structural block of the Mine Mountain area forms the western border of Yucca Flat, east of the southern Eleana Range and southeast of the autochthonous syncline of Chainman Shale and Tippipah Limestone (fig. 3). Mine Mountain is the type area of the "Mine Mountain thrust" system (Orkild, 1968; Barnes, Hinrichs, and others, 1963) that was interpreted in the 1960's to be a subsidiary sheet beneath the fundamental "CP thrust" (Belted Range thrust of this report) in the Yucca Flat area (Barnes and Poole, 1968; Carr, 1984). The main structural characteristic of this "Mine Mountain thrust" was that it placed Devonian and Silurian dolomite on top of Mississippian clastic rocks of the Eleana Formation.

More recent work has shown that no simple kinematic model accounts for all the diverse features in the Mine Mountain area that were embodied in the original concept of the "Mine Mountain thrust." As described below and in 


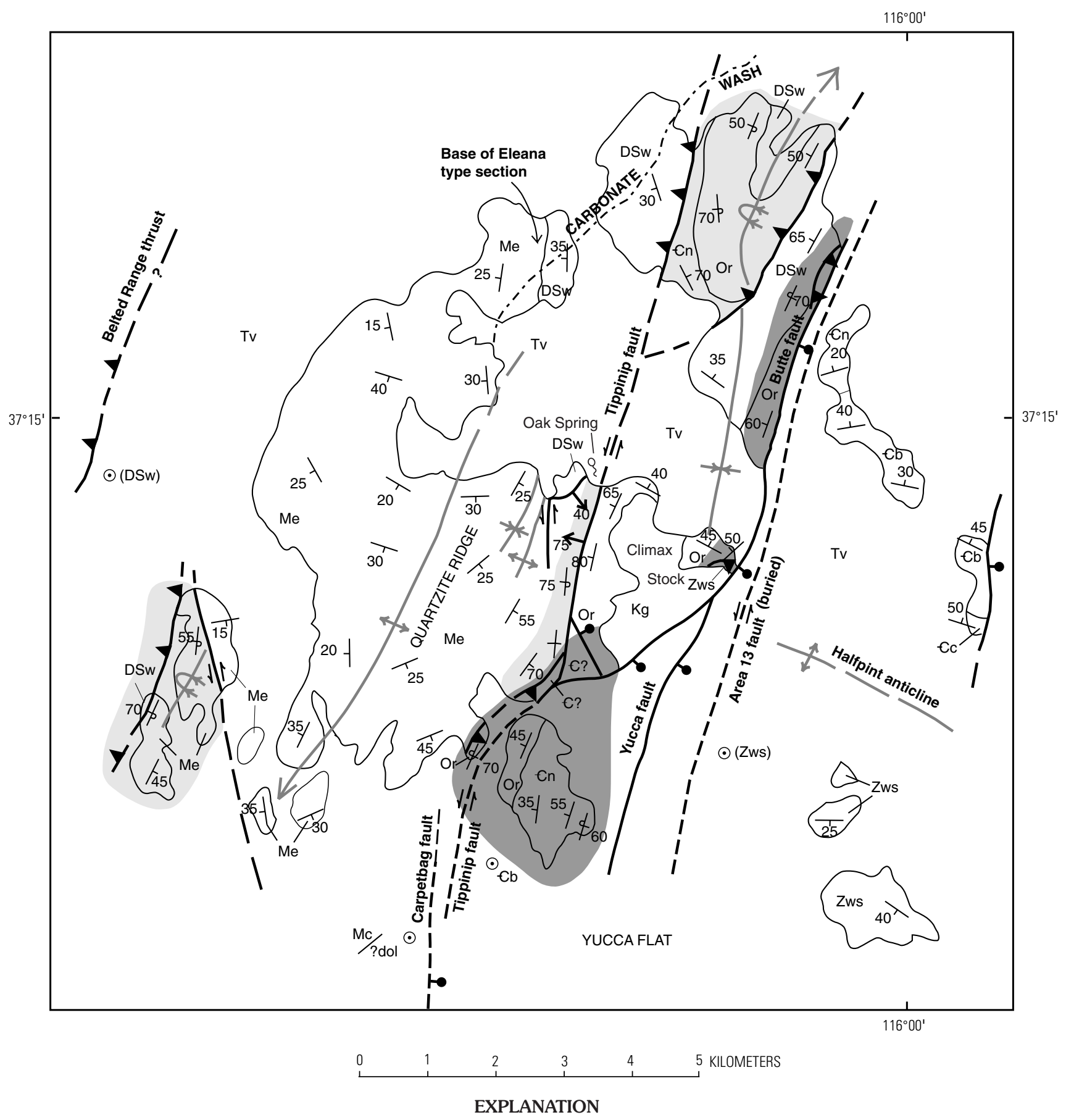

$\odot \quad$ Pre-Tertiary rocks in

(Zws) borehole or tunnel

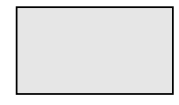

Foreland-vergent

Hinterland-vergent

Figure 7. Geologic map of the Carbonate Wash-Oak Spring area. The Yucca fault-Butte fault structure postdates Miocene volcanism and offsets 14-Ma units by about $335 \mathrm{~m}$ down-to-the-east. The Area 13 fault (see text), which places west-dipping Ordovician rocks (west) against north-dipping Cambrian rocks (east), also passes through this area but is buried by volcanic rocks. Geology based on Cole (1997) and sources cited therein. Dip of faults shown by arrow symbol; see figs. 1 and 3 for explanation of other symbols. 
following sections, we now recognize that the Mine Mountain area shows clear evidence of both east- and west-vergent thrusting, as well as evidence of younger extensional faulting (fig. 8) (Cole and Cashman, 1997). Further, Trexler and others (1996) have shown that part of the original "Mine Mountain thrust" between the Guilmette Limestone and the Eleana Formation along the Mine Mountain crest is largely a depositional, rather than structural, contact.

\section{PALEOGEOGRAPHIC CONTEXT}

We next describe some stratigraphic and sedimentological features of the Mine Mountain Devonian and Mississippian sections because they differ from sections elsewhere and these differences bear on the interpretation of structure in this area. Our description pertains to the Eleana Formation and the underlying Devonian carbonate rocks at Mine Mountain (Cole and Cashman, 1997), as well as to the section at Shoshone Mountain along strike to the southwest that is quite similar (Trexler and others, 1996).

The Devonian carbonate rocks in the Mine Mountain-Shoshone Mountain area are similar to the Simonson Dolomite and Guilmette Formation of the Spotted Range and eastern Nevada, but both units are abnormally thin west of Yucca Flat (J. Warme, Colorado School of Mines, oral commun., 1994; Trexler and others, 1996). The Guilmette, in particular, is less than half its regional thickness at Mine Mountain and is capped by a prominent, brecciated quartzite bed. The distribution and nature of this quartzite breccia and fabrics in the underlying dolomitized limestone indicate that the Guilmette was dissolved under karst conditions. Better exposures at Shoshone Mountain show that these persistent quartzite beds in the upper Guilmette were fractured as they collapsed into karst sinkholes, prior to deposition of the overlying Mississippian clastic strata (Trexler and others, 1996; Cole and Cashman, 1997).

Shale beds that overlie the karst breccia at both Mine Mountain and Shoshone Mountain contain a transgressive conglomerate at the base that marks the return of marine depositional conditions. The shale sequence contains thin, debris-flow limestone beds in its lower $30 \mathrm{~m}$ that are late Kinderhookian in age (Trexler and others, 1996; Cole and Cashman, 1997). These lines of evidence taken together indicate a period of karst erosion and nondeposition in these localities that lasted from Late Devonian (probably postFrasnian) to Early Mississippian time (through most of the Kinderhookian stage). No other Devonian-Mississippian sections in and around the Nevada Test Site are known to record this depositional hiatus (Trexler and others, 1996).

A measured section of the Eleana at Mine Mountain that covers the period from late Kinderhookian through middle Chesterian time is just more than $1 \mathrm{~km}$ thick, in contrast with at least $2 \mathrm{~km}$ of measured section in the central Eleana Range (Trexler and others, 1996; Trexler and Cashman, 1997). The Eleana at Mine Mountain is further distinguished by overall finer grain sizes, scarcity of conglomerate, higher proportion of calcareous detritus and wider distribution of it through time, and by the inclusion of black carbonaceous shale and impure quartzite beds in its uppermost part. This latter assemblage strongly resembles the late Chesterian part of the Chainman Shale correlated with the Scotty Wash Quartzite (Trexler and others, 1996).

The Eleana in the Mine Mountain area seems to record a depositional environment that may have been transitional between the Eleana turbidite trough to the west and the Chainman Shale muddy shelf to the east. The fact that the Mine Mountain-Shoshone Mountain sections both record an erosional gap in Late Devonian-Early Mississippian time suggests that a paleotopographic high persisted in this region and that this feature may have also controlled the sedimentological isolation of the Eleana and Chainman depositional basins (Trexler and others, 1996).

Conodont thermal maturation values in the Mine Mountain area are also anomalous with respect to adjoining areas. Ten samples from the Mine Mountain-Shoshone Mountain areas that range in age from Early-Middle Silurian to Late Mississippian, all have CAI values of 3.0 or less (A.G. Harris, written commun., 1993; Grow and others, 1994; Cole and others, 1997; Cole and Cashman, 1997). In contrast, samples from throughout the stratigraphic section in the wider region from the Eleana Range, Halfpint Range, Spotted Range, and Bare Mountain all have CAI values of 4.5 or greater (Grow and others, 1994). This relationship underscores the notion that the Mine Mountain-Shoshone Mountain area did not experience as much depositional accumulation or tectonic burial as other areas.

The paleogeographic arrangement of these various depositional environments is not well defined, but it seems reasonable to infer that the Mine Mountain-Shoshone Mountain section was originally deposited in a location west of the Chainman basin. This model is supported by the prevalence of western-derived chert-lithic sand in the Eleana, and by the craton-derived recycled quartz sand typical in the Chainman Shale (Trexler and others, 1996). The present location of the Mine Mountain block east and south of the Chainman Shale in the Syncline Ridge area, and northwest of Chainman in the CP Hills indicates that Mine Mountain was thrust eastward over the Chainman (fig. 4C). Evidence of that relationship is provided by drill hole UE- $1 \mathrm{~m}$, located at the northeast corner of the Mine Mountain block (fig. 8). This hole penetrated about $55 \mathrm{~m}$ of heterogeneous chert-lithic sandstone, pebbly mudstone, siltstone, and bioclastic limestone before crossing a fault into uniform black siltstone of the Chainman Shale down to $150 \mathrm{~m}$ (Cole and others, 1997). Small-scale folds throughout the Eleana at Mine Mountain show the imprint of eastward (foreland) vergence.

\section{FORELAND-VERGENT STRUCTURES}

The Mine Mountain block contains a broad, gently north plunging irregular anticline in the Eleana Formation. That fold is similar in scale and orientation to the Syncline 


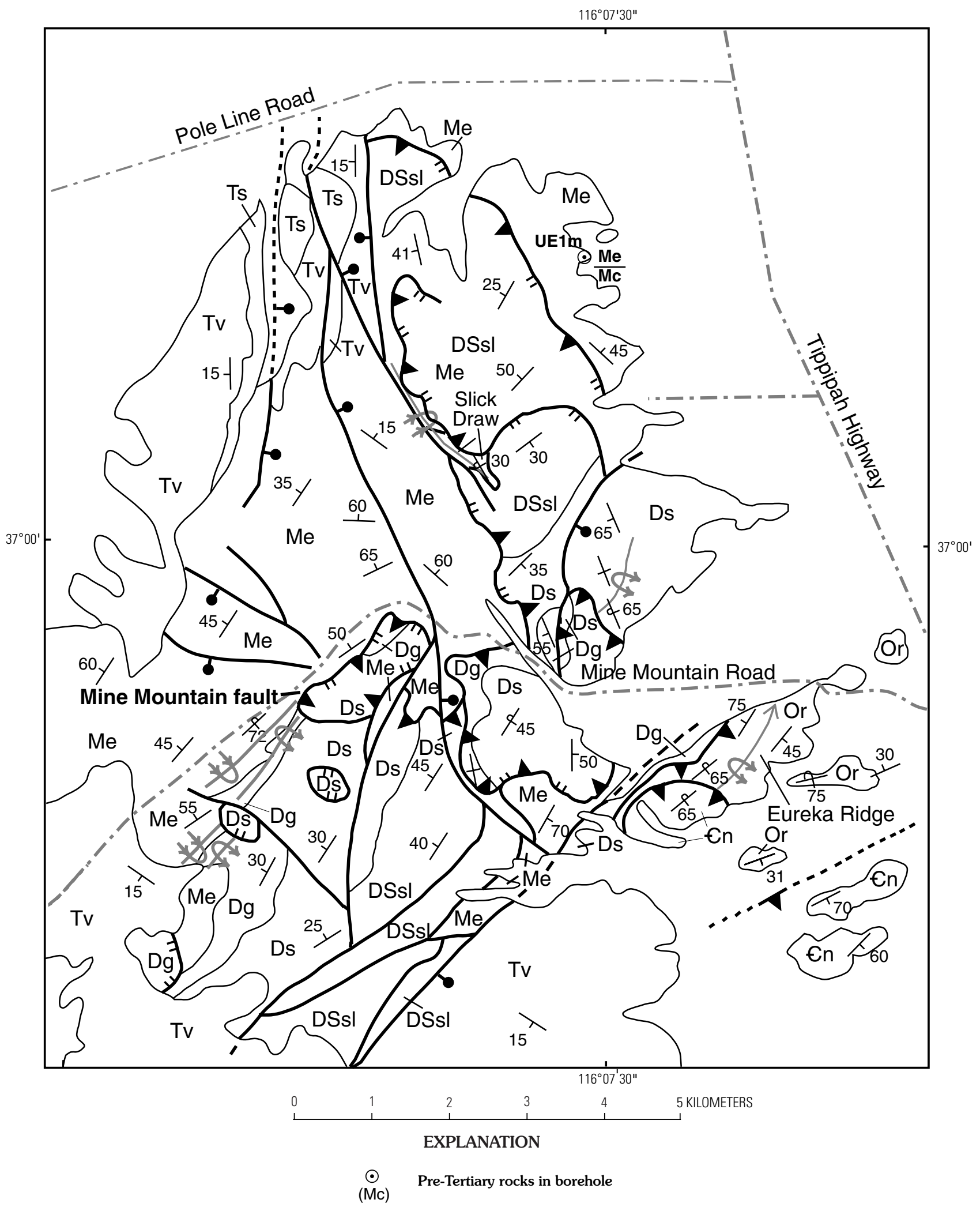

Figure 8. Geologic map of the Mine Mountain area based on Cole and others (1989, 1994) and Cole and Cashman (1997). Ts, Tertiary sedimentary rocks; Dg, Guilmette Formation; Ds, Simonson dolomite; DSsl, undivided dolomites, generally equivalent to Sevy Dolomite and Laketown Dolomite; see figs. 1 and 3 for explanation of other symbols. 
Ridge fold in Tippipah Limestone to the northwest and most likely was formed during foreland-vergent thrust emplacement. The west-facing limb of the Mine Mountain anticline is a continuous section from the Silurian and Lower Devonian Sevy Dolomite, through the Simonson Dolomite and the Guilmette Formation, and then through the Mississippian Eleana up to the Chesterian limestone turbidite beds (Trexler and others, 1996; Cole and Cashman, 1997). These Upper Mississippian carbonate beds can be traced continuously around the nose of the anticline in the north. The east-facing limb of the fold is only apparent north of the Mine Mountain Road in the Eleana (fig. 8); elsewhere, it is strongly overprinted by younger hinterland-vergent folding and thrusting that are described later in this report.

The northeastern flank of the Mine Mountain area displays a conspicuous block of Sevy and Simonson Dolomite on top of the Eleana (fig. 8). This dolomite block faces southeast, opposite the northwest-dipping carbonate section that stratigraphically underlies the Eleana south of the Mine Mountain Road. The northern block of dolomite is considerably less cherty and less diverse lithically than the dolomites beneath the Eleana to the south. We believe these relationships support our inferences from the minor structures that the northern dolomite block was originally emplaced westward over the Eleana, as described in the following section on the CP thrust.

Additional complications in the northern Mine Mountain area are due to younger extensional faulting (Cole and others, 1989; Hudson and Cole, 1993). Detailed kinematic studies by Hudson show that the last significant movement on most faults between dolomite and Eleana resulted from extension in a northeast-southwest direction. This faulting is also displayed south of the Mine Mountain Road along the Mine Mountain crest, where the kinematic extension direction is nearly parallel to the stratigraphic contact between the Guilmette and the Eleana (Cole and others, 1994; Trexler and others, 1996). Thus, although fracturing and brecciation are extensive, the effect on the continuous stratigraphic contact is minimal.

\section{CALICO HILLS}

Paleozoic rocks are exposed over an area of about 10 $\mathrm{km}^{2}$ in the core of the Calico Hills (fig. 9), located west and south of the Mine Mountain-Shoshone Mountain area (Cole and Cashman, 1998). Previous mapping in this area identified complicated relationships between footwall Mississippian shale and unnamed Devonian and Mississippian(?) carbonate and clastic rocks in thrust relationship above it (McKay and Williams, 1964; Orkild and O'Connor, 1970; Simonds, 1989; F.W. Simonds and R.B. Scott, written commun., 1994). Our work here has confirmed this broad outline of the geology and has provided considerable new data about the stratigraphy and structure (Cole and Cashman, 1998). In addition, our detailed mapping, paleontology, sedimentology, and structural studies document features that are not as well preserved elsewhere (Trexler and others, 1996; Cashman and Cole, 1996; Cole and Cashman, 1998).

The main foreland-vergent feature of the Paleozoic rocks in the Calico Hills is a thrust that placed a Middle Devonian and younger section eastward on top of the Chainman Shale. This feature reflects footwall duplexing beneath the Belted Range thrust, which is inferred to lie to the north beneath Miocene volcanic cover. The thrust in the Calico Hills is well defined and has been mapped for several kilometers along strike (fig. 9). At its leading edge in the northeastern Calico Hills, the thrust dips gently west and has a hanging-wall anticline that is slightly overturned toward the foreland (fig. 10). Footwall deformation seems to be relatively limited near the fault, but outcrop is generally poor in the footwall Chainman Shale. The hanging wall includes rocks somewhat older than late Early Devonian but largely exposes a complete section with strata as young as late Early Mississippian (late Kinderhookian) of siltstone, chert, and limestone (Trexler and others, 1996; Cole and Cashman, 1998). The thrust cuts gently up through the hanging-wall section toward the northeast.

The Mississippian clastic rocks define a coherent stratigraphic package with distinctive units that we were able to map in some detail in the Calico Hills (Cole and Cashman, 1998). The lowermost unit is a flaggy brown siltstone (unit $\mathrm{M}_{1}$, fig. 9) that traces out several major north-trending folds. These structures are geometrically congruent with the foreland-vergent thrust, and we interpret them to have formed at the same time under the same regional stresses.

Rocks in the Calico Hills are also notably deformed by hinterland-vergent structures that cause map-scale folding of the foreland-vergent thrust and its related folds, as well as numerous local folds and warps on outcrop scale (Cashman and Cole, 1996; Cole and Cashman, 1998). These younger features are described in the following section devoted to hinterland vergence.

\section{CP THRUST AND RELATED HINTERLAND VERGENCE}

Early mapping in the Nevada Test Site area identified several substantial folds and faults that seemed to require vergence in the direction of the hinterland; that is, counter to the sense of displacement on the Belted Range thrust. They were generally not recognized as a distinct group of structures at the time, but rather were interpreted as manifestations of large-amplitude folds in the Belted Range thrust (called the "CP thrust" in those earlier reports; see, for example, McKeown and others, 1976; Carr, 1984).

Work in the Cottonwood Mountains to the west of Death Valley by Snow and Wernicke (1989) identified a significant zone of hinterland-vergent folding contained between two 


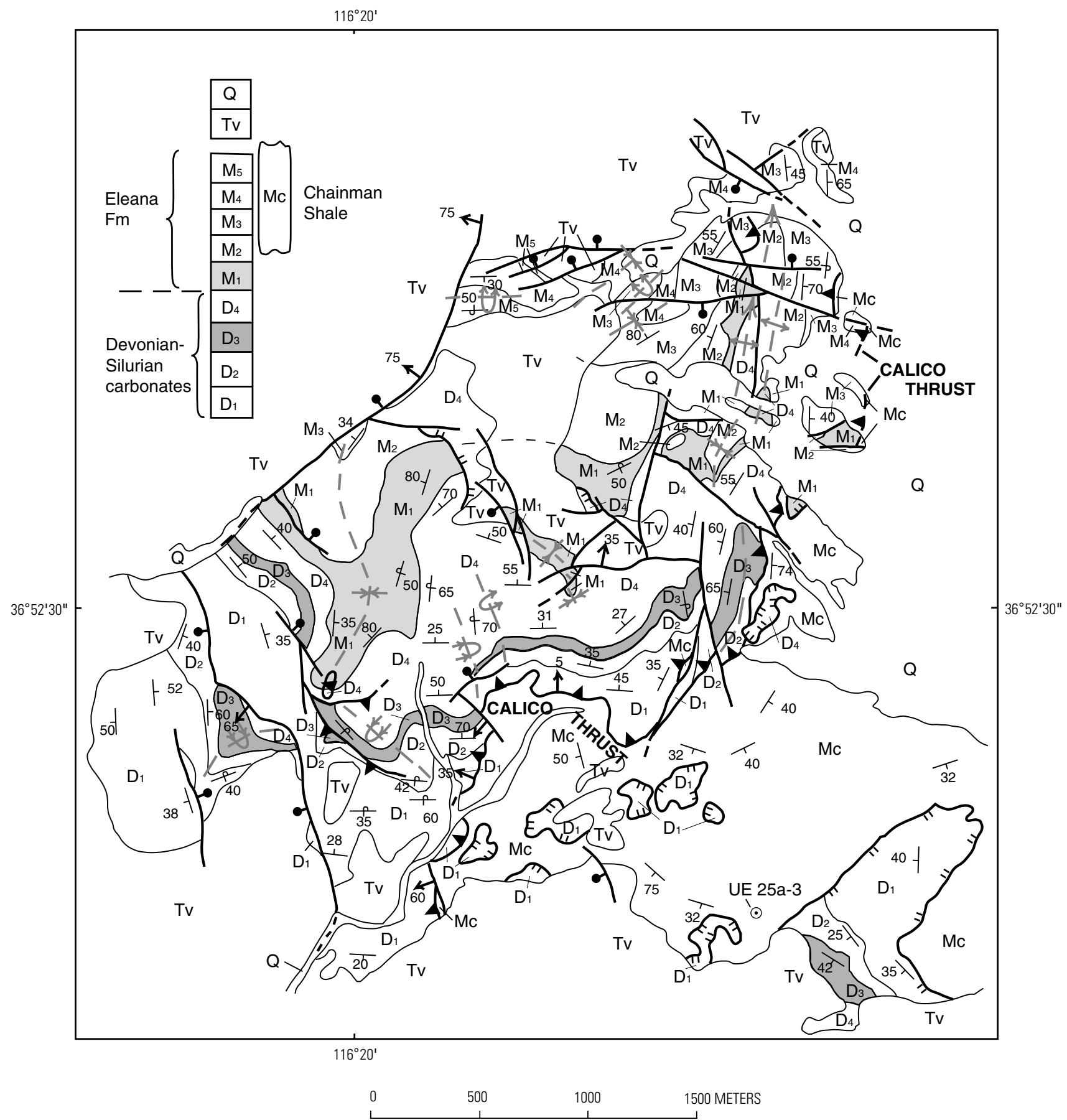

Figure 9. Geologic map of the Calico Hills area, based on Cole and Cashman (1998). Stratigraphic subdivisions of the Devonian and Mississippian sections are also described in Trexler and others (1996). Extensional faults (indicated by hachures) have been generalized for simplicity. See figs. 1 and 3 for explanation of symbols.

major foreland-vergent thrust sheets. They correlated this unique zone of antithetic deformation with structures in the Nevada Test Site area on the basis of map relations and published cross sections (Snow and Wernicke, 1989). Caskey (1991) remapped parts of the CP Hills and established that the apparent westward vergence in late Paleozoic rocks depicted by McKeown and others (1976) was real, and he identified other Nevada Test Site locations with the same sense of folding (Caskey and Schweickert, 1992).

It is now possible to summarize the extent of this hinterland-vergent deformation in the area, based on our detailed mapping in several areas, biostratigraphic work (especially for drill-hole samples from beneath Yucca Flat), and structural studies by many. Conclusions and inferences 


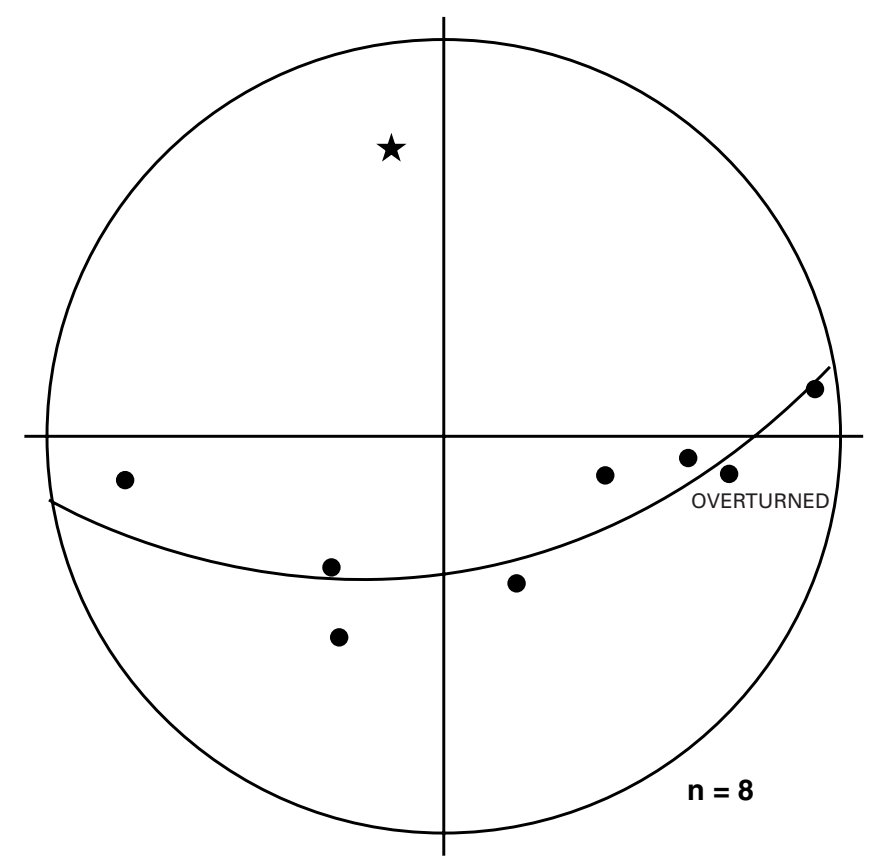

Figure 10. Stereogram showing poles to bedding for an overturned fold on the leading edge of the Calico thrust; pole (star) to statistical best-fit great-circle distribution for eight poles to bedding shows that the fold plunges gently north-northwest, parallel to the trace of the foreland-vergent thrust.

by Snow, Wernicke, Caskey, and others prior to 1994 can be shown to be correct in some instances but inconsistent in others, based on the geologic mapping and stratigraphic refinements we have achieved since their work. The regional framework for this deformation is described below and depicted in a 1:100,000-scale summary structural compilation by Cole (1997).

In broad outline, the hinterland-vergent deformation in the Nevada Test Site region defines an irregular band of folding and thrusting that is generally located on the foreland side of the leading edge of the footwall duplex zone beneath the Belted Range thrust (fig. 3). This zone of hinterland vergence trends roughly parallel to the Belted Range zone on a regional scale, but the apparent coincidence of trends does not bear out in detailed mapping. Folding related to the hinterland vergence tends to be irregularly developed in various areas and ranges from discontinuous zones of small-scale kinks to map-scale folds with strongly overturned limbs. Axial trends and fold forms also tend to be irregular because the structures are developed on previously folded surfaces or because the younger folds are preferentially developed in more deformable rock units or on favorably oriented fold limbs of earlier structures. As described below for the Calico Hills area, there is local evidence for more than one set of superposed folds with differing styles and trends, all of which result from hinterland vergence.

This regional zone of hinterland-vergent deformation, located on the foreland side of the Belted Range thrust, is referred to as the CP thrust system, following Caskey and Schweickert (1992). The regional structural position and the sense of vergence are the defining characteristics of the CP thrust system. The relative ages of rocks above and below local CP faults are variable because the CP system cuts through a previously deformed section.

\section{CP HILLS}

The Paleozoic rocks exposed in the CP Hills display some of the more complex structure of the Nevada Test Site region due to the interfering effects of multiple deformations of differing styles (fig. 11). Recent remapping of the area by Caskey (1991) and our work summarized in Cole and others (1994, 1997) and Trexler and others (1996) allow for some simplification and clarification.

Neogene faults add complexity by locally offsetting the pre-Tertiary rocks by hundreds of meters. Several northtrending high-angle faults cut the CP Hills and displace Miocene volcanic rocks down-to-the-east on the east side and down-to-the-west on the west. Displacement on these faults is generally less than $100 \mathrm{~m}$, and their principal effect is to tilt panels of rock to accommodate east-west extension related to formation of the Yucca Flat alluvial basin (Caskey, 1991; Cole and others, 1994; Hudson, 1997). The CP Hills are bounded to the east by a major normal fault that passes through Yucca Pass and marks the western edge of the postmiddle Miocene Yucca Flat basin. The CP Hills nonetheless remain a relatively intact structural high along the French Peak accommodation zone (Guth, 1990; Hudson, 1997) between young alluvial basins to the north and south. Displacements on the post-volcanic faults tend to die out along strike northward and do not appear to significantly affect map relations in the Paleozoic rocks.

Some low-angle faults within the Paleozoic section (fig. 11) are interpreted to have formed during extension following the major contractional deformation and prior to Miocene volcanism (Cole and others, 1989, 1994; Caskey, 1991). In the CP Hills, these faults generally occur between the Bonanza King Formation above and the Carrara Formation below. They cut bedding both above and below, and they are marked by simple truncation of the Carrara in the footwall but by intense brecciation along the bottom of the Bonanza King hanging wall (Cole and others, 1994, 1997). Their total effect on preexisting relationships within the Paleozoic rocks is difficult to quantify, but the fact that not much section appears to be missing across them suggests the effect is not major. These faults resemble the extensional faults in the Mine Mountain area, where brecciation at the base of the hanging wall is considerable and yet the amount of displacement is shown to be small (Cole and others, 1989; Hudson and Cole, 1993; Cole and Cashman, 1997).

The CP Hills (exclusive of effects of Neogene deformations) essentially expose Lower Cambrian and younger rocks 


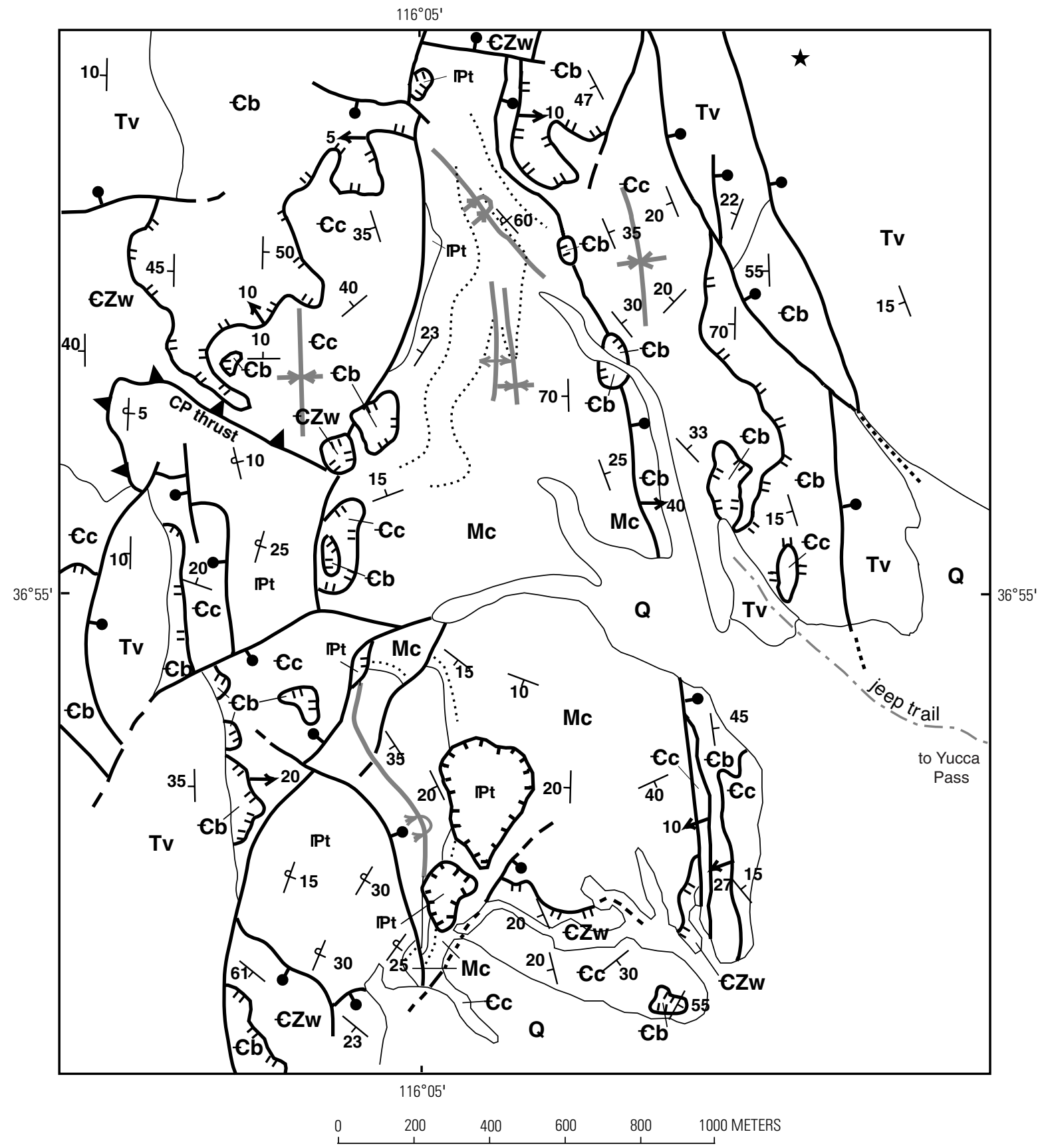

EXPLANATION
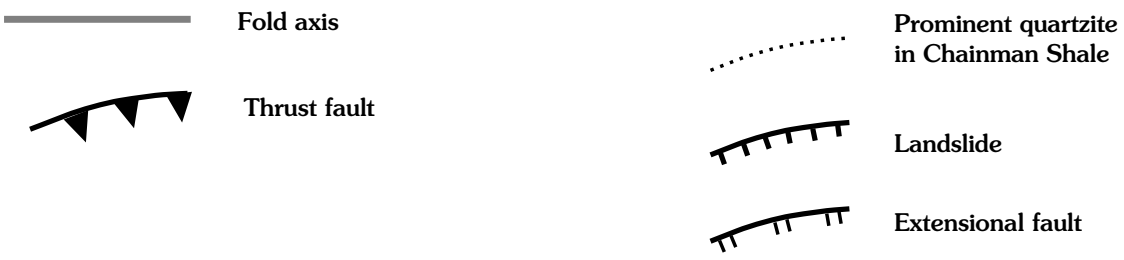

Figure 11. Geologic map of the CP Hills area. Geology based on Caskey (1991) and on unpublished mapping by the authors. Q, alluvium; Tv, Miocene volcanic rocks $\mathbb{P t}$, Tippipah Limestone; Mc, Chainman Shale and Scotty Wash Quartzite (prominent beds indicated by dotted lines); Cb, Bonanza King Formation; Cc, Carrara Formation; CZw, Wood Canyon Formation and Zabriskie Quartzite. Drill hole ER-6-2 (see text) is located 3,500 m north of the star symbol in the northeast corner of the figure. 
(Zabriskie Quartzite, Carrara Formation, and Bonanza King Formation) in a generally west-dipping section on top of strongly overturned Upper Mississippian Chainman Shale and Pennsylvanian Tippipah Limestone. The middle and upper parts of the Carrara Formation on the east side of the CP Hills are overturned as much as $45^{\circ}$ toward the west (fig. $4 C$ ). However, the amount of overturning diminishes upsection to the west as the hinge of an overturned hanging-wall anticline is approached at the base of the Bonanza King Formation (Caskey, 1991; Cole and others, 1997). To the west of a down-dropped block of Miocene volcanic rocks, the Carrara is gently folded about axes that plunge gently north in the hanging wall of the CP thrust (fig. 11).

The footwall block (generally bounded by post-thrust, north-striking, high-angle faults that offset the CP thrust) exposes the upper part of the Chainman Shale. This section contains several substantial quartzite beds correlated with the Scotty Wash Quartzite of eastern Nevada (Titus, 1992; Trexler and others, 1996) and limestone conglomerate marker beds that define the structure. Upright, west-dipping beds in the Chainman become progressively steeper northward and fold over to the west to dips as low as $15^{\circ}$ to $20^{\circ}$. The hinge line of the best preserved overturned syncline trends about $\mathrm{N}$. $30^{\circ} \mathrm{W}$. (fig. 11). The Tippipah Limestone above the Chainman is also overturned in a north- to northwest-striking syncline in the southwesternmost CP Hills (fig. 11), and the overturned limb locally dips less than $5^{\circ}$ (Caskey, 1991; Cole and others, 1997).

Northward in the CP Hills above the thrust, the Bonanza King Formation generally dips northward. However, it too is warped into map-scale overturned folds along the eastern edge of the range. These folds verge toward the northwest, based on the strike and facing direction of the overturned beds (Caskey, 1991). The overturned section persists up to the Dunderberg Shale at the base of the Nopah Formation in the northernmost CP Hills (fig. 11) (McKeown and others, 1976; Caskey, 1991; Cole and others, 1997).

ER-6-2, a 1,050-m-deep hole drilled in 1994 at the northeast margin of the CP Hills, revealed several critical elements of the geology in this area (Cole and others, 1997). It was continuously cored from about $610 \mathrm{~m}$ to its total depth of $1,050 \mathrm{~m}$. The hole penetrated $730 \mathrm{~m}$ of probable Bonanza King dolomite before crossing the CP thrust into an overturned section of Upper Devonian Guilmette Formation and Mississippian Chainman Shale (Trexler and others, 1996; Cole and others, 1997). This hole not only demonstrated the persistence of the CP thrust in the subsurface north of its outcrop limits but also showed that the Chainman Shale is a continuous unit northward toward Mine Mountain. The ER-6-2 hole further demonstrated that the $\mathrm{CP}$ thrust cuts upsection through the entire Mississippian (estimated to be as thick as 1,200 m; Trexler and others, 1996) over a lateral distance of less than $3 \mathrm{~km}$ in the CP Hills. We base this conclusion on the cutoff of the depositional base of the Chainman preserved in the ER-6-2 core (Trexler and others, 1996; Cole and others,
1997) and the cutoff of the upper Chainman contact with the Tippipah Limestone in the direction of tectonic transport in the western CP Hills.

The map pattern and attitudes of beds in the CP Hills demonstrate the sinuous nature of $\mathrm{CP}$ thrust deformation, which we believe is typical in the region. The Carboniferous rocks of the thrust footwall exposed in the southwestern CP Hills show progressive changes in vergence direction over relatively short distances (fig. 11). In the southern area of exposure, beds are overturned northwestward; in the middle, beds are overturned westward; and in the north, beds are overturned southwestward. Beds in the hanging-wall Cambrian section indicate southwest, west, and northwest vergence from south to north. These changes in orientation appear to reflect irregularities in the strain distribution because they blend continuously from one trend to the next. However, minor structures have not been studied in detail here, and the possibility of superimposed vergence directions cannot be ruled out.

Early workers in this area proposed that the Cambrian section on top of the Carboniferous rocks in the CP Hills had been emplaced during foreland-vergent contraction (Barnes and Poole, 1968; Carr, 1984). McKeown and others (1976) correctly recognized the westward overturning in the Carrara at CP Pass and indicated westward emplacement of the $\mathrm{CP}$ allochthon in a structural cross sections of the area but did not propose a regional context. The $\mathrm{CP}$ thrust system described in this paper provides the necessary framework to understand these relations. The internal stratigraphy of the Carrara Formation (Palmer and Halley, 1979; Cole, unpub. mapping) leaves no doubt about the sense of overturning in the hanging wall, and it is confirmed by the sense of overturning in the footwall in the southwestern CP Hills and in the ER-6-2 drill hole.

Stratigraphic and sedimentologic evidence confirm the Belted Range footwall as the source of the CP thrust hanging-wall block. This hanging-wall section in the CP Hills, consisting nominally of the uppermost Zabriskie Quartzite and the Carrara, Bonanza King, and Nopah Formations, compares favorably with the similar section in the northern Halfpint Range $25 \mathrm{~km}$ to the northeast (Cole, 1997, and unpub. mapping) and with the Groom Range section $50 \mathrm{~km}$ to the northeast, described by Barnes and Christiansen (1967). These sections are all interpreted in this paper to belong to the footwall of the Belted Range thrust. In contrast, the same chronologic section in the northern Belted Range in the hanging-wall ramp of the Belted Range thrust is radically different in thickness, facies, and sedimentological character (A.R. Palmer, Institute for Cambrian Studies, written commun., 1994; Cole, 1997; compare with Ekren and others, 1967, 1971). These observations preclude the possibility that the Cambrian section in the CP Hills might have initially been emplaced toward the foreland and later thrust back toward the hinterland. 


\section{MINE MOUNTAIN AREA}

The easternmost flank of the Mine Mountain area contains displaced thrust blocks with folds that show overturning toward the west (fig. 8). Many of these thrusts are local in scale and can be traced out over areas of less than a square kilometer. The local nature of deformation is reinforced by the fact that the sense of overturning of beds along the leading edge of these thrust sheets is not unidirectional, but typically describes a fan-shaped pattern.

Some of the boundaries between panels of opposing dip direction in these blocks had previously been mapped as extensional normal faults (Cole and others, 1989, 1994) because detailed kinematic studies showed the youngest slip sense on subsidiary fractures was extensional (Hudson and Cole, 1993). However, subsequent field study has demonstrated that some of the boundaries are flat lying fold-hinge surfaces; individual beds can be traced continuously along strike from upright to vertical to overturned attitudes. Smallscale overturned folds near some fault surfaces further indicate the effects of contraction related to either foreland or hinterland vergence. Extensional strain is undeniably recorded in these rocks by slip-lines on diverse fracture sets and, locally, by displaced blocks. Nonetheless, we conclude that the contractional deformation is the principal factor in the shape and distribution of rock units in the Mine Mountain area.

The knobs north and south of the Mine Mountain Road on the eastern margin of the hills are capped by Guilmette Formation limestone that dips steeply or is overturned westward (Cole and Cashman, 1997). The Simonson Formation dolomite on the east-facing slopes of both knobs is also generally overturned toward the west. A third block of Simonson and Sevy dolomites at lat $37^{\circ} 00^{\prime} 00$ N., long $116^{\circ} 07^{\prime} 30$ $\mathrm{W}$. contains a large westward-overturned anticline whose hinge surface dips gently northeastward (fig. 8). The westward overturning is further expressed in the central part of the northern Mine Mountains beneath the thrust slab of brecciated dolomite (area designated "Slick Draw" in Cole and others, 1994; Cole and Cashman, 1997). In this location, consistent sense of grading observed in bioclastic limestone beds shows that the Eleana Formation beneath the dolomite is overturned to attitudes as shallow as $30^{\circ}$ (fig. 8) (Cole and Cashman, 1997).

Northwest- and west-vergent thrusts and folds are also well displayed south of the Mine Mountain Road (fig. 8), east of the Mine Mountain hills. The east-northeast-trending Eureka Ridge that is crossed by the road (fig. 8) exposes an imbricate stack of thrust slices of Cambrian Nopah Formation, Ordovician Eureka Quartzite and Antelope Valley Limestone, and Devonian strata (McKeown and others, 1976; Cole and others, 1989, 1994, 1997; Cole and Cashman, 1997). From south to north across this ridge, southdipping overturned Nopah beds are thrust over an asymmetric anticline in the upper Antelope Valley Limestone,
Eureka Quartzite, and the lower Ely Springs Dolomite, which in turn is thrust over the Guilmette Formation. At the westernmost end of this ridge, northwest-dipping beds in the Guilmette Formation beneath the Ordovician sheet clearly steepen and overturn toward the west and northwest. This entire thrust stack structurally overlies the Eleana Formation a short distance to the northwest, although the contact is not exposed. The thrust fault in this location has probably been modified by Tertiary faulting, based on displacements of the Miocene volcanic section along strike a short distance to the southwest.

The structural relief represented by these imbricate thrust slices south of the Mine Mountain Road is considerable. In aggregate, they effectively bring the Upper Cambrian Nopah Formation of the Belted Range thrust footwall to the same structural level as the Mississippian Eleana Formation in the hanging wall of one of the Belted Range thrust duplex blocks (Cole and Cashman, 1997). The net stratigraphic slip is inferred to exceed 4 to $5 \mathrm{~km}$ in the footwall alone. It is notable in this context that conodonts from samples of the Antelope Valley on the east end of this ridge record a much higher temperature thermal history than the Devonian and Mississippian rocks in the central Mine Mountain block. The Ordovician samples show CAI values of $3,4.5$, and 6, compared to values of 2 to 3 in the middle Paleozoic units (A.G. Harris, written commun., 1993; Grow and others, 1994; Trexler and others, 1996; Cole and Cashman, 1997). The contrasting thermal signatures reflect the greater stratigraphic and structural burial that has been reversed by displacements on structures of the CP thrust system.

Lower Paleozoic rocks are also present in the subsurface of Yucca Flat near the eastern flank of Mine Mountain and farther north near Syncline Ridge (fig. 12) (Cole, 1997; Cole and others, 1997). Ordovician strata, identified on the basis of microfossils or distinctive lithology (Eureka Quartzite), were penetrated in three exploratory holes on the west side of central Yucca Flat. Two other holes penetrated Chainman Shale between the Ordovician rocks and the eastern foot of the Mine Mountain and Syncline Ridge hills. We conclude from these relationships that the Ordovician section forms the leading edge of the CP thrust zone in westcentral Yucca Flat.

\section{SYNCLINE RIDGE AND NORTHWESTERN YUCCA FLAT}

The eastern part of northern Syncline Ridge displays moderately to strongly overturned beds in the Pennsylvanian Tippipah Limestone (Orkild, 1963; Cole, 1997; Cole and others, 1997). In southern and central Syncline Ridge, upright beds are generally inclined at $45^{\circ}$ or less, but the attitudes become progressively steeper north of the gap in the ridge (fig. $4 A$ ) as the strike swings from north-northeast to 


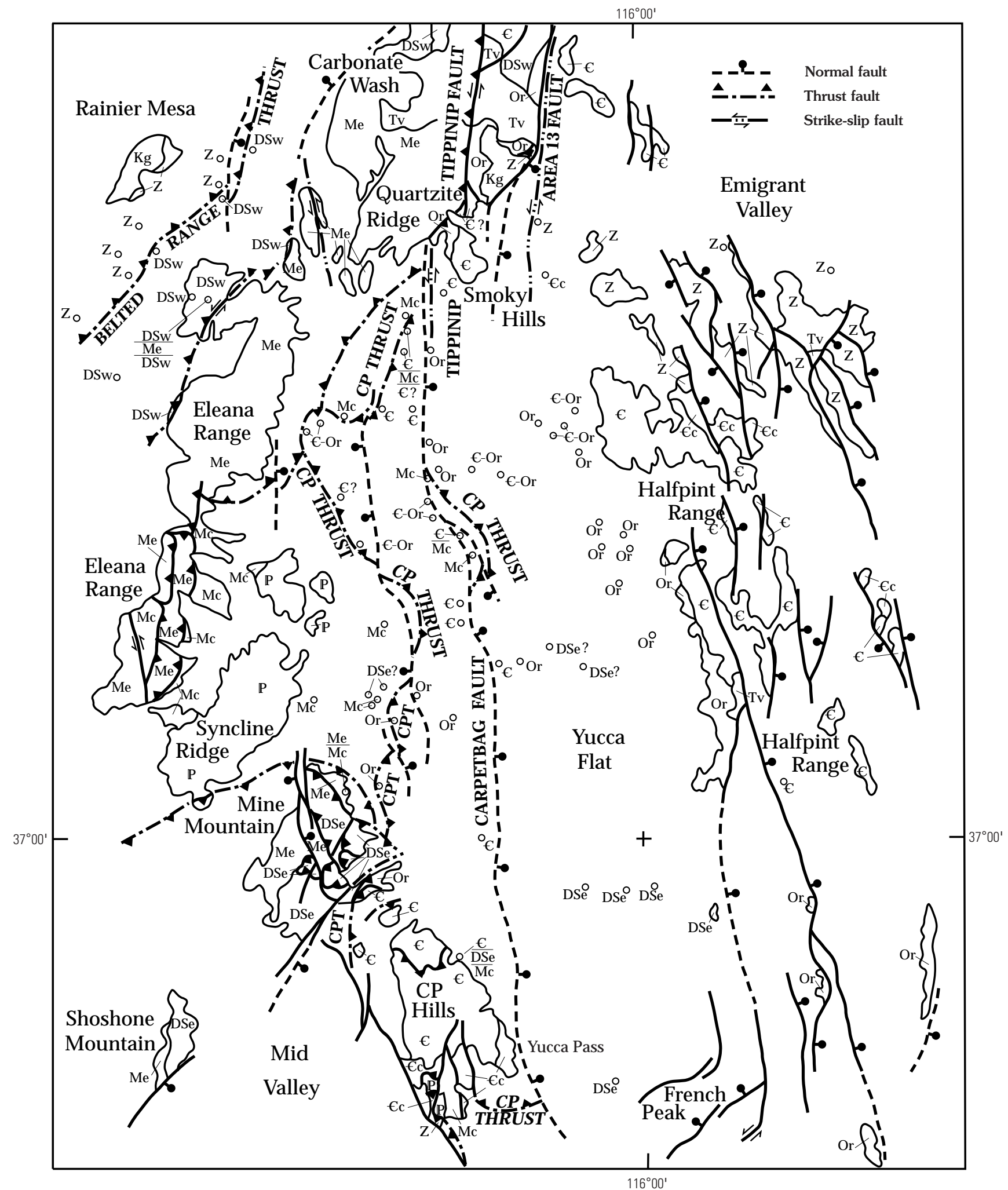

Figure 12. Map showing stratigraphic units penetrated in drill holes beneath Yucca Flat. Interpretation based on identification of conodonts (A. Harris, written commun., 1991-96; Cole and others, 1997), presence of other microfossils, identification of distinctive lithology or mineralogy by Cole, or on a combination of these factors. See figs. 1 and 3 for explanation of symbols. 
more northerly. In the isolated hill at the northeast end of the ridge, beds in the lower Tippipah Limestone overturn westward to dips as low as $40^{\circ}$. These north-striking beds then progressively swing to a westerly orientation before swinging back to a northerly trend (Orkild, 1963) (fig. 4A). These changes in orientation of overturned beds may simply reflect rather disharmonic folding in easily deformed, well-bedded limestone sections, or they may indicate a component of sinistral slip in addition to the westerly vergence.

The upper plate of the $\mathrm{CP}$ thrust system is not exposed at Syncline Ridge but is interpreted to have been penetrated in exploratory drill holes near the eastern flank of the ridge (fig. 12). Approximately $1.5 \mathrm{~km}$ northeast of the north end of the Ridge where the Tippipah displays southwest-verging overturned folds, a drill hole penetrated limestone that contains phosphatic brachiopods typical of Cambrian-Ordovician parts of the section (well UE-4ac; Cole and others, 1997). About $5 \mathrm{~km}$ to the north, one well drilled about $2 \mathrm{~km}$ east of the Eleana Range front penetrated Cambrian-Ordovician dolomite (well UE-2ce) and another well, located a few hundred meters farther east, penetrated Mississippian Chainman Shale (well U2cr; Cole and others, 1997). Numerous wells south of Quartzite Ridge in northwesternmost Yucca Flat (fig. 12) penetrated shattered Cambrian-Ordovician dolomite above black, pyritic Chainman Shale on top of more brecciated dolomite (U.S. Geological Survey, 1974; Cole and others, 1997). These relationships suggest the leading edge of the $\mathrm{CP}$ thrust is imbricated at this location, similar to the situation described southeast of Mine Mountain.

The CP thrust system is expressed at the surface in northern Yucca Flat at the north end of the Smoky Hills, where Ordovician strata are thrust northwestward over the Eleana Formation (Barnes, Houser, and Poole, 1963; Cole, 1997). Upper Cambrian rocks along the east side of the Smoky Hills show west- and northwest-verging mesoscopic folds superimposed on older east-verging warps. The northernmost vestige of the $\mathrm{CP}$ thrust system within the Yucca Flat area is interpreted from relations preserved in the contact aureole of the Cretaceous Climax stock. Micaceous quartzites that most likely belong to the Late Proterozoic Wood Canyon Formation are exposed southeast of calc-silicate gneisses that are correlated with the Ordovician Pogonip Group (Houser and Poole, 1960; Barnes, Houser, and Poole, 1963). This relationship indicates vergence toward the northwest, consistent with $\mathrm{CP}$ thrust kinematics.

\section{CALICO HILLS}

Thirty kilometers southwest of southern Yucca Flat, the Paleozoic rocks exposed in the Calico Hills area provide an exceptionally well preserved record of the hinterlandvergent deformation (fig. 9). Cashman and Cole (1996) and Cole and Cashman (1998) have documented the overprinting relationships in the Calico Hills that clearly establish that the hinterland-vergent folding is younger than the foreland-vergent thrusting.

In detail, the evidence suggests there are actually two sets of structures that deform the earlier foreland-vergent thrust that places the Devonian to Lower Mississippian section over the Chainman Shale. The first overprinting structures are small folds and kinks that are irregularly developed across the Calico Hills in spaced deformational bands that trend northeast and indicate vergence toward the northwest. In addition, the northwest vergence produces a tight fold in the thrust contact between Devonian dolomites and the Chainman Shale in the central Calico Hills (fig. 9). This deformational event may also be responsible for the eastward flexure of the axial surface of the originally north trending syncline in the Lower Mississippian units (rocks of North Pass of Cole and Cashman, 1998) that was formed in the upper plate of the foreland-vergent thrust.

A still younger episode of superposed deformation produces folds that generally verge toward the north and south. This event is particularly well developed in the southwestern Calico Hills just north of the Miocene volcanic cover (Cole and Cashman, 1998). As north- and east-trending beds are tracked into this zone, attitudes become increasingly steeper and eventually roll over to overturned, south-dipping orientations (fig. 9). Overturned beds locally dip as shallowly as $25^{\circ}$, indicating that the overriding block (not exposed in the Calico Hills) may have been nearby above the current level of exposure. This north-south contraction also shows up as small kinks and warps in the central and northern Calico Hills, and some of these folds contain overturned south limbs.

\section{BARE MOUNTAIN}

The interaction of foreland- and hinterland-vergent structures is also displayed in the Bare Mountain area, west of the Calico Hills, but the geographic trends of structural elements are distinct from those in the Yucca Flat area due to the arcuate oroflexural bend in this region. Analysis of trends among Paleozoic units at Bare Mountain also has to be adjusted to account for significant Neogene deformation. Bare Mountain has migrated northwestward since Miocene time as a result of diffuse dextral shear and clockwise vertical-axis rotations that are recorded in the Miocene volcanic rocks (Hudson and others, 1994; C. Fridrich, oral commun., 1998).

Structural elements at Bare Mountain that we correlate with the foreland-vergent Belted Range thrust verge toward the south-southeast (Monsen and others, 1992; Cole, 1997) rather than toward the east. The southern "tail" of Bare Mountain displays a CP-thrust-related structure designated the Panama thrust (fig. 13), which emplaces Late Proterozoic Wood Canyon Formation and Stirling Quartzite over the Lower Cambrian section to the north (Carr and Monsen, 1988; 


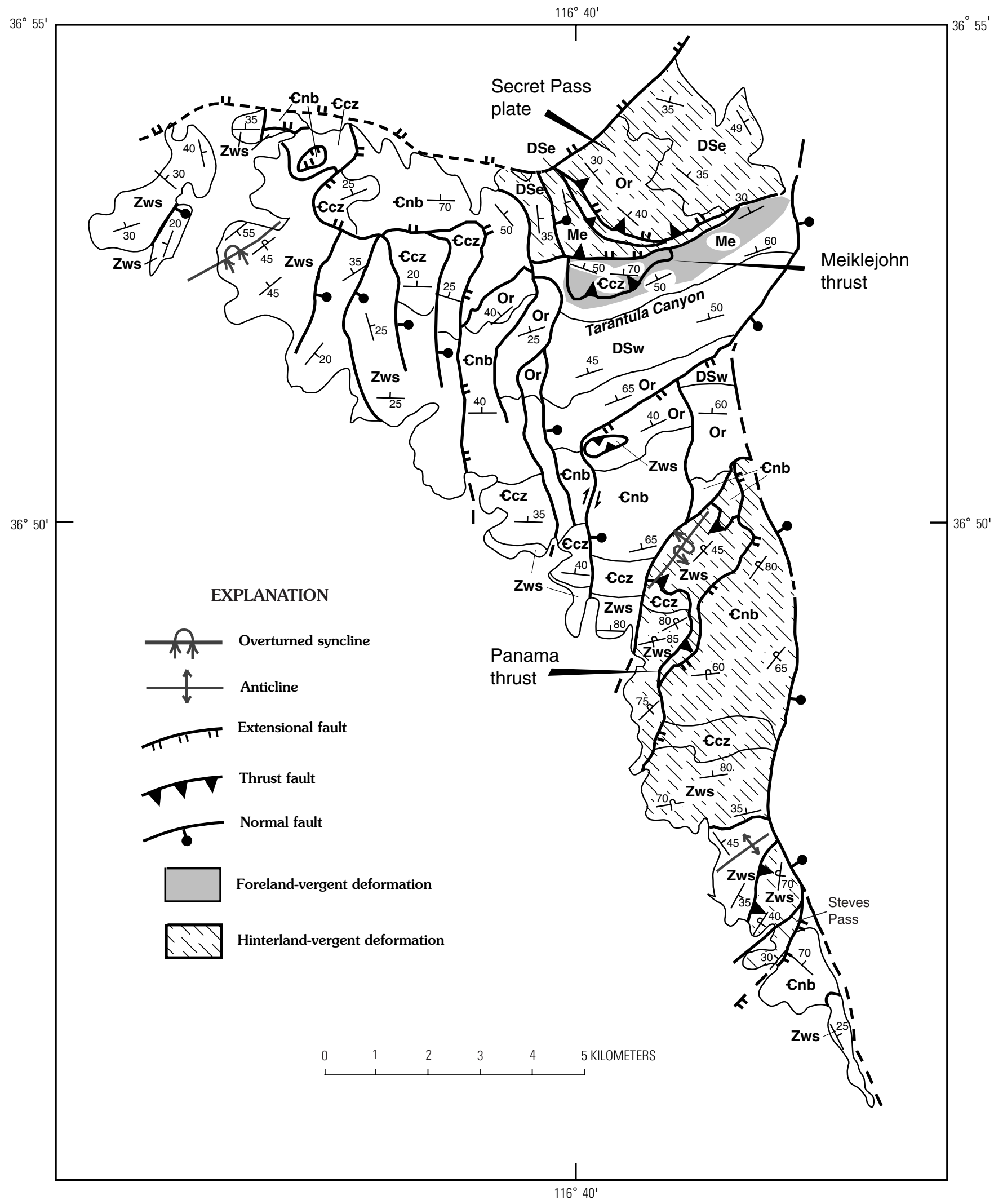

Figure 13. Geologic map of the Bare Mountain area; pre-Tertiary geology based on Monsen and others (1992) and Cole (1997). See figs. 1 and 3 for explanation of symbols. 
Monsen and others, 1992). The Panama thrust trends northeastward across the range, and the overturned beds in both the hanging wall and the footwall indicate vergence toward the north and northwest, in the direction of the hinterland. Similar structures within the Stirling Quartzite at the south end of Bare Mountain near Steves Pass show the same overturning toward the northwest (Monsen and others, 1992).

Somewhat indirect evidence indicates the northeasternmost block of Bare Mountain was also emplaced from the south or southeast in the direction of the hinterland. The block in question (designated the Secret Pass plate, Carr and Monsen, 1988; Trexler and others, 1996) lies directly above the slivers of Zabriskie Quartzite and Carrara Formation that comprise the hanging-wall block of the Belted Range thrust (fig. 13; see description above). The block above the Belted Range hanging wall consists of an east- and northeast-dipping section of Devonian-Mississippian and an overlying fault block of Ordovician-Silurian-Devonian rocks (Monsen and others, 1992). The Devonian Fluorspar Canyon Formation in the Secret Pass plate is a shallow-water dolomite with common reef debris, and the overlying Eleana Formation is a heterogeneous assemblage of siltstone, sandstone, bedded chert, and limestone turbidite beds (Trexler and others, 1996). The time-equivalent section in Tarantula Canyon to the south (fig. 13; the footwall to the Belted Range thrust) consists of the Devonian Tarantula Canyon Formation, which contains exceptional debris-flow conglomerate beds, and a different section of the Eleana Formation that was deposited in deep water. The contrast between the two sections is remarkable in light of their present proximity. Their respective depositional environments clearly establish that the Secret Pass plate was deposited in shallower water and closer to the continental margin than the rocks exposed in Tarantula Canyon. From these relations, we infer that the Secret Pass plate was emplaced over the Tarantula Canyon strata toward the north or northwest in the direction of the hinterland.

\section{CARBONATE WASH AND THE OAK SPRING AREA}

Geologic relationships in the Carbonate Wash-Oak Spring area north of Yucca Flat require an even younger event of strike-slip deformation superimposed on both the foreland-vergent thrust-related structures and the hinterlandvergent folds and faults. The Belted Range north of Yucca Flat is largely covered by Miocene volcanic rocks, but deep erosion along the margin of the volcanic tableland has exposed a critical section of Paleozoic rocks in the Carbonate Wash drainage (fig. 7). Three major north-south fault blocks are displayed here that show contractional structures that are chiefly related to the Belted Range thrust, but their present juxtaposition requires other (additional) mechanisms. Geologic relations to the south beneath volcanic cover around Oak Spring and the Cretaceous Climax stock (fig.7) reflect similar structural styles in equivalent fault blocks - structures that also seem inconsistent with simple foreland-vergent contraction. In addition, both the Carbonate Wash and Oak Spring areas are faulted against the northern Halfpint Range block, which exposes geology characterized by significantly different depositional facies and structural attitudes.

Geologic relationships for the Carbonate Wash area are based on mapping by Rogers and Noble (1969), on paleontological studies by Harris (A.G. Harris, written commun., 1993, 1994; Grow and others, 1994; Cole and others, 1997), and on two reconnaissance trips by the authors to the area in 1994 and 1995. Our understanding of the geology in the Climax stock area reflects considerable new mapping by Cole, results of our stratigraphic and structural studies (Trexler and others, 1996), and additional paleontologic work by Harris. Prior geologic maps by Houser and Poole (1960), Barnes, Houser, and Poole (1963), and Sargent and Orkild (1973) provided a useful regional guide for our more recent detailed work.

Geologic relations in the Carbonate Wash-Oak Spring area present several puzzling aspects, and we make no claim to have resolved them all. The features described below require more than a single deformational event to account for the map relationships. In addition to the effects of forelandvergent folding and thrusting and local manifestations of the hinterland-vergent CP thrust system, there is evidence for substantial strike-slip displacement. In the following section, we describe the stratigraphic and structural framework for this complex region in order to evaluate the evidence for strike-slip faulting.

\section{STRATIGRAPHIC CONSIDERATIONS}

The western block in the Carbonate Wash area is a continuation of the northern Eleana Range block that includes the broad south-plunging anticline of Quartzite Ridge (fig. 7). The broad folding between Carbonate Wash and Quartzite Ridge is coaxial with the anticline at Quartzite Ridge and defines a gently southwest plunging axis (fig. $5 A$ ). The units of the Eleana Formation at Quartzite Ridge can be traced continuously downsection to their depositional base on Upper Devonian carbonate rocks at the type locality of the Eleana Formation at Carbonate Wash (Poole and others, 1961; Trexler and others, 1996). Here, both the Eleana and the underlying unnamed carbonates dip moderately to the west and are undeformed (fig. 7). The limestones and dolomites in the Devonian section were deposited in a submarine-slope environment and contain abundant, coarse debrisflow beds. A sample from such a debris flow in the lowest part of this section in the north fork canyon of Carbonate Wash produced Middle Devonian conodonts (A.G. Harris, written commun., 1994). 
Earlier workers inferred a thrust fault in the covered interval between two Devonian sections in Carbonate Wash (Rogers and Noble, 1969). Less than 500 m northeast of this sample locality beneath the basal Eleana and across Miocene volcanic cover (fig. 7), west-dipping Devonian rocks are exposed at the top of a section that is continuous down to the top of the Ordovician Ely Springs Dolomite (Rogers and Noble, 1969). The Devonian rocks are massive, thick-bedded dolomite that were thought to correlate with the lower Nevada Formation, representing eastern-facies equivalents to the limestone and dolomite section to the west that underlies the basal Eleana Formation. This interpretation, stated in a footnote on the geologic map of the Oak Spring Butte quadrangle (Rogers and Noble, 1969), also led to the inference that a major thrust fault must pass beneath the covered interval and serve to juxtapose two age-equivalent sections deposited in differing environments.

Data obtained in this study show, to the contrary, that the two sections of Devonian are in normal stratigraphic order and that no large fault needs to pass between them. Bedding attitudes in both sections are similar in dip and orientation, and close examination of the outcrops closest to the inferred thrust fault reveal no folding, brecciation, or solution cleavage. Such structures are commonly associated with thrust faults in the duplex zone in the footwall of the Belted Range thrust (see above). The strongest evidence for stratigraphic continuity comes from biostratigraphic results obtained for this study. A sample of dolomite from the highest outcrops of the eastern ("Nevada Formation") section is early Pragian (Early Devonian) and "is at least 10 million years older than" the sample collected from the base of the western section (A.G. Harris, written commun., 1994). These results indicate the two sections are not the same age. Rather, these strata on either side of the covered interval appear to comprise a continuous stratigraphic section. This section records the transition at about the end of the Early Devonian in this area from shelfal depositional environments and thick-bedded dolomite to slope conditions with debris flows and interbedded limestone and dolomite.

Thus, the western block of the Carbonate Wash terrane exposes a gently west-dipping homoclinal section that can be traced continuously east from Lower Mississippian to Upper Ordovician rocks. This block is truncated to the east by a high-angle fault that has about $50 \mathrm{~m}$ of post-Miocene normal offset (down-to-the-west; Rogers and Noble, 1969). However, a substantial pre-Tertiary structure must also pass through this location because the block to the east contains an east-verging, north-plunging, overturned syncline that folds Upper Cambrian through Silurian rocks.

\section{EVIDENCE FOR SUPERIMPOSED DEFORMATION}

The Tippinip fault probably has a complex history of movement because several incongruous elements are juxtaposed across it. In the Oak Spring area (fig. 7), we believe that the Tippinip fault is a southward continuation of the preTertiary fault that bounds the western block of the Carbonate Wash section (Houser and Poole, 1960; Barnes, Houser, and Poole, 1963; Cole and others, 1997). Here, the Tippinip fault places overturned west-dipping beds of Mississippian Eleana Formation on top of west-dipping, contact-metamorphosed marble correlated with the Ordovician Pogonip Group (Houser and Poole, 1960). This is the same young-over-old relationship noted above between the western and central blocks exposed in Carbonate Wash. The Tippinip fault appears to postdate the Belted Range thrusting because it cuts out beds and locally steepens bedding (figs. 6, 7) in the east limb of the Quartzite Ridge anticline (Cole and others, 1994, 1997; Cole, 1997).

The central block in Carbonate Wash, which contains the east-overturned syncline of Cambrian to Silurian strata, is truncated on the west side by the Tippinip fault (see above). On the east side (fig. 7), a high-angle, pre-Miocene fault cuts off the east limb of the syncline as well as its axial zone, and thus the fault is younger than the folding (Rogers and Noble, 1969).

The eastern block in Carbonate Wash contains an open, north-plunging syncline of Ordovician through Upper Devonian rocks (fig. 7). This syncline may continue south beneath Miocene volcanic cover to the area of the Climax granite stock where rocks correlated with the Pogonip Group are intruded and recrystallized to marble. The overall pattern of bedding attitudes is consistent with this interpretation, although much of the folding near the intrusion may be due to flowage during emplacement. The west side of the stock was mapped as a west-facing attenuated section of upright formations in the Pogonip Group, but no fossils were obtained in these calc-silicate marbles to support identification of specific stratigraphic units (Houser and Poole, 1960; Barnes, Houser, and Poole, 1963). We believe an alternate interpretation should also be considered: that is, the marbles formed from an overturned section of Ordovician and younger rock (Eureka Quartzite and above) rather than an upright section. This interpretation would resolve the strain incompatibility indicated by two tilted sections facing each other across a fault with reverse-sense kinematics (see cross section in Barnes, Houser, and Poole, 1963). This strain incompatibility could also be explained by strike-slip displacement on the Tippinip fault (discussed below).

The three fault blocks of the Carbonate Wash and Oak Spring areas expose different parts of the lower and middle Paleozoic section, but there is stratigraphic overlap among the blocks. We interpret them to all belong to the same regional thrust sheet because they were mapped as correlative units with comparable thicknesses in all blocks (Rogers and Noble, 1969). Security restrictions on the Nellis Air Force Base Bombing and Gunnery Range preclude more detailed comparisons, but available color aerial photographs and enhanced satellite images show close similarities 
between comparable sections and support the notion of facies equivalence. For example, the Antelope Valley Limestone of the Ordovician Pogonip Group in both the central and eastern blocks contains several discrete quartzite beds in the section beneath the Eureka Quartzite (these beds were mistakenly mapped as fault slivers in the eastern block; Rogers and Noble, 1969).

\section{AREA 13 FAULT AND STRIKE-SLIP DISPLACEMENTS}

A significant change in facies occurs between the Carbonate Wash blocks and the equivalent strata in the Halfpint Range to the east (fig. 7). The present boundary between these terranes coincides with the Butte fault-Yucca fault system, which has about $335 \mathrm{~m}$ of post-middle Miocene displacement (Barnes, Houser, and Poole, 1963; Rogers and Noble, 1969). Evidence presented below shows that this young fault disguises a far more substantial structure in the underlying Paleozoic rocks. To distinguish the two, we designate the older buried structure as the Area 13 fault (fig. 7).

Both the Nopah Formation and the Pogonip Group rocks are dissimilar between the Halfpint Range and the terranes west of the Area 13 fault. The Nopah in the central block of Carbonate Wash and in the Smoky Hills is notably less dolomitic than the Nopah in the central Halfpint Range, and the Pogonip is distinctly thicker west of the Area 13 fault. The Silurian and Devonian carbonate sections contain more limestone and slope-facies rocks in Carbonate Wash than they do to the east in the Groom Range (Tschanz and Pampeyan, 1970) or in the Spotted Range (Barnes and others, 1982).

These distinctions are believed to reflect fundamental differences in depositional facies across the Area 13 fault. Enhanced satellite imagery for the region shows that the contrasts between eastern and western sections are identifiable over large areas and that the change is not gradational but abrupt at the location of the Area 13 fault.

The Area 13 fault is also identified as a significant crustal boundary on the basis of mismatched structures in its east and west blocks. Folding west of the Area 13 fault can be reliably attributed to southeast-directed, foreland-vergent deformation in the footwall of the Belted Range thrust. However, beds in the northern Halfpint Range strike nearly eastwest, approximately perpendicular to the Area 13 fault, and define the flanks of a broad fold designated the Halfpint anticline (fig. 7) (Barnes, Hinrichs, and others, 1963; Carr, 1974, 1984). This fold exposes the oldest sedimentary rocks in the Nevada Test Site region in its core (Late Proterozoic Johnnie Formation), even though this part of the northern Halfpint Range has been dropped down more than $335 \mathrm{~m}$ since middle Miocene time.
To summarize, the present location of the Area 13 fault coincides with a major structural boundary within the Paleozoic section. Rocks east and west of this structure differ substantially in their depositional facies, structural level, and structural orientation. The sense of displacement on the Area 13 fault is not clear from outcrop relations. One observation, in addition to the deeper structural level exposed to the east, suggests the east side was displaced upward. The east flank of the open syncline in the eastern block of the Carbonate Wash area becomes progressively steeper eastward in proximity to the Area 13 fault, some beds are overturned toward the west, and the Eureka Quartzite is locally thrust westward over the Ely Springs Dolomite (Rogers and Noble, 1969). These features suggest a component of shortening, with west-vergence, on the buried Area 13 structure.

Although we cannot presently resolve all the complexities in the Carbonate Wash-Oak Spring area, we believe the overall relationships are best explained with a substantial component of strike-slip deformation. The fault blocks are bounded by high-angle faults that suggest a sigmoidal pattern. The refolding of the Eleana and the truncation of beds along Tippinip fault suggest a sinistral component to the contraction (Cole and others, 1994, 1997). The apparent deflection of the synclinal axis in the central block in Carbonate Wash hints at a similar sinistral-oblique strain.

The strike-slip mechanism also appears to be the most straightforward explanation for the side-by-side placement of otherwise incongruous rocks. For example, the fact that the central block in Carbonate Wash is a syncline of older rocks flanked on both sides by younger strata of the same thrust sheet is irreconcilable with simple contractional strain, but these geometric relations can be achieved with strike-slip offset. Similarly, the large change in orientation of contractional structures east and west of the Area 13 fault is simpler to explain with strike-slip motion.

\section{SPECTER RANGE THRUST}

None of the deformation described above pertaining to the Belted Range thrust, the CP thrust system, or the strikeslip faulting appears to affect geologic relations east of Yucca Flat or east and south of the CP Hills and the Calico Hills. Paleozoic rocks exposed east and south of Frenchman Flat in the Spotted Range and Specter Range (fig. 14) all appear to belong to the same regional thrust plate, which is the Belted Range footwall. Depositional facies, although not studied in detail for this report, appear similar in these areas to equivalent sections in the Halfpint Range and the Ranger Mountains for the Cambrian, Silurian, and Devonian carbonates. Only the Mississippian section is decidedly different between the Chainman Shale facies of Yucca Flat and the carbonate-platform facies of the Spotted Range (see Trexler and others, 1996). 
Folding and thrust faulting are evident in the Spotted Range and the Specter Range on either side of Mercury Valley (Sargent and Stewart, 1971; Barnes and others, 1982). To the west, in the Specter Range (fig. 14), Cambrian Bonanza King Formation is thrust south-southeastward over upturned Ordovician rocks in the structure designated the Specter Range thrust (Burchfiel, 1965; Snow, 1992). East of Mercury, Nev., in the Spotted Range, folded Bonanza King and minor Nopah Formation along the range crest lie above folded and overturned rocks as young as Late Mississippian in a structure designated the Mercury klippe of the Spotted Range thrust (fig. 14) (Barnes and others, 1982). Previous interpretations held that the thrusts in the Specter Range and in the Spotted Range are one and the same (Barnes and Poole, 1968; Barnes and others, 1982; Carr, 1984; Snow and Wernicke, 1989; Caskey and Schweickert, 1992). These prior models inferred that Cambrian hanging-wall strata rest on progressively younger footwall strata toward the southeast because the Spotted Range-Specter Range thrust cut upsection through a footwall ramp in the direction of tectonic transport.

We believe that this interpretation is contradicted by the map relationships and that the Specter Range thrust and the Spotted Range thrust represent different structural levels.

The Specter Range thrust was reconnoitered by Burchfiel (1965) and mapped at 1:24,000-scale by Hinrichs (1968) and by Sargent and Stewart (1971). The following description is summarized from those sources; no new work has been conducted in this area since the 1960's. The thrust is exposed along a strike length of about $2 \mathrm{~km}$ in the eastern Specter Range (fig. 14), and its location beneath alluvium is inferred on the basis of stratigraphic relations for another 10 to $15 \mathrm{~km}$ to the west. Numerous small-displacement, highangle faults have been mapped in the area that are most likely related to Tertiary deformation. In addition, several lowangle fault complexes were mapped by Sargent and Stewart (1971) that are extensional in nature (section is cut out across them) and predate the high-angle faults. Neither set of structures has a significant effect on map relationships; they are ignored in the following description.

The upper plate of the Specter Range thrust dips gently toward the north and is broadly warped about east-northeasttrending folds (fig. 14) (Cole, 1997). The deepest stratigraphic level exposed in the hanging wall is Late Proterozoic Wood Canyon Formation, which is opposite Upper Ordovician rocks in the footwall. Eastward along the thrust, the rocks at the base of the hanging wall become progressively younger and reach the upper part of the lower Bonanza King at the range margin at Mercury Valley (fig. 14) (Sargent and Stewart, 1971). Rocks in the footwall become progressively older in the same eastward traverse and are correlated with the upper Nopah Formation at the Mercury Valley range margin. Sargent and Stewart (1971) also mapped an irregular patch of Ordovician rocks south of the trace of the Spotted Range thrust (see A, fig. 14) that they interpreted as a folded(?) klippe of the thrust. The leading edge of this block carries Upper Ordovician rock onto Silurian and Devonian strata. Both relationships suggest diminishing throw toward the southeast.

Over a lateral distance of about $6 \mathrm{~km}$, the apparent stratigraphic separation across the Specter Range thrust diminishes eastward from at least $2.8 \mathrm{~km}$ to about $1.1 \mathrm{~km}$. If continued eastward at a constant rate, the separation across the thrust would decline to zero in the area of the western Mercury Valley (fig. 14). We believe this projection is accurate and that the Specter Range thrust dies out eastward beneath Mercury Valley.

Additional regional relationships indicate the Specter Range thrust cannot connect with the Mercury klippe of the Spotted Range thrust. At the western end of Mercury Valley, the upper plate of the Specter Range thrust consists of southand east-dipping Nopah Formation. This section can be traced eastward through low hills northwest of Mercury into the Ordovician section north of Mercury camp (fig. 14) (Hinrichs, 1968; Barnes and others, 1982; Cole, 1997). These rocks, in turn, can be traced in stratigraphic continuity through the Silurian section at Mercury Pass, and then southeastward into the Devonian and Mississippian rocks in the northern Spotted Range. This continuous stratigraphic section, culminating in the Middle Mississippian limestones, is the footwall block to the Cambrian Bonanza King section that comprises the Mercury klippe (Barnes and others, 1982). We can only conclude that the Cambrian rocks in the Mercury klippe represent a different structural level than the Cambrian rocks in the hanging wall of the Specter Range thrust.

\section{MERCURY KLIPPE AND THE SPOTTED RANGE THRUST}

The map relationships surrounding the Mercury klippe (fig. 14) clearly indicate it was emplaced toward the foreland in a south-southeast direction. Both the leading edge of the hanging wall and the underlying footwall are overturned in that direction, and folds in the hanging-wall block are consistent with those kinematics (Barnes and others, 1982). At the eastern edge of the Mercury quadrangle, the Mercury klippe appears to reach a lateral ramp where beds on both sides of the fault are overturned eastward and the amount of stratigraphic throw declines markedly (Barnes and others, 1982).

The peculiar feature about the Mercury klippe is that the footwall rocks along its trailing (northwestern) edge show overturning toward the northwest; that is, in the direction of

Figure 14 (facing page). Geologic map of the Specter Range-Spotted Range area; pre-Tertiary geology based on Burchfiel (1965), Sargent and Stewart (1971), Barnes and others (1982), and Cole (1997). See figs. 1 and 3 for explanation of symbols. 


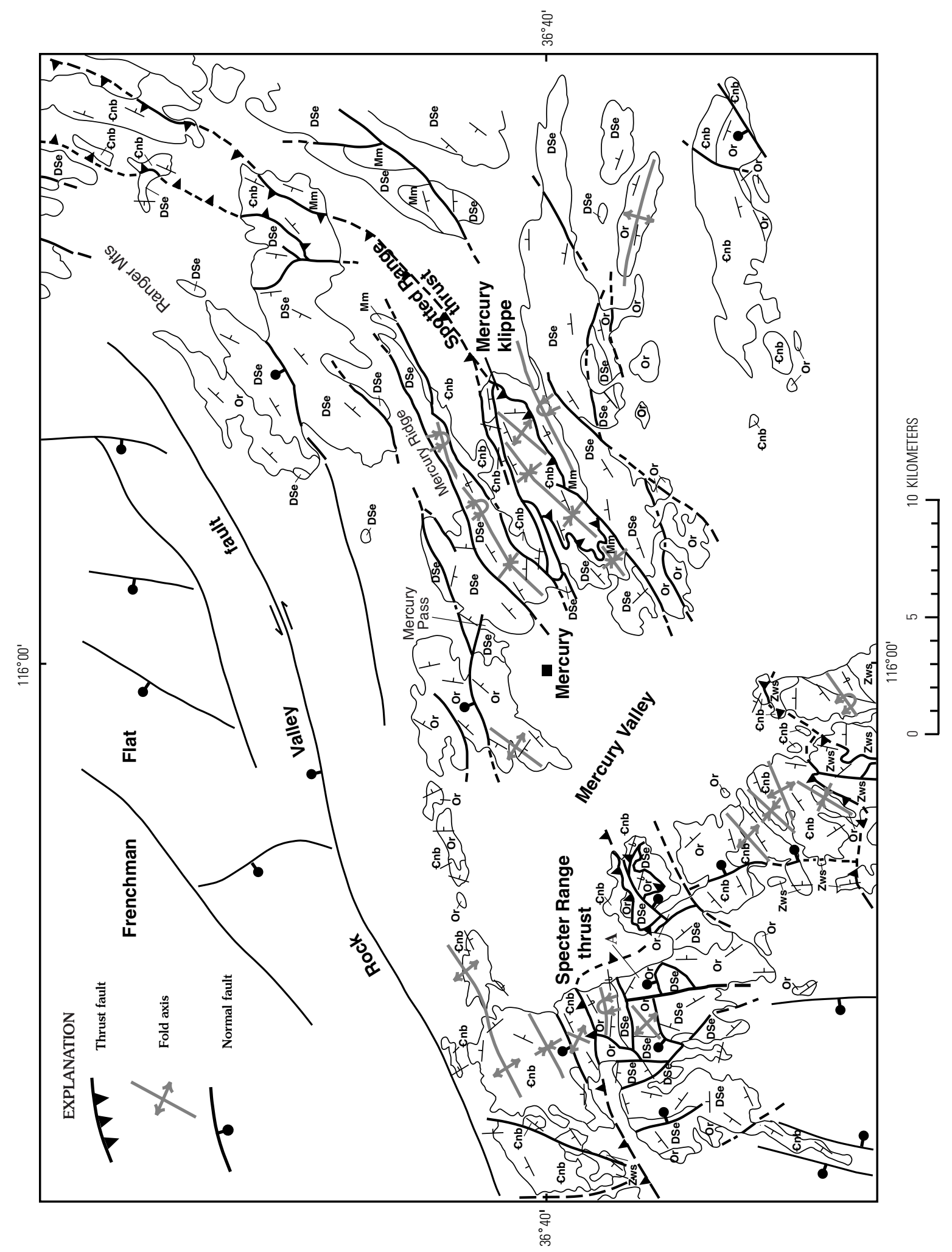


the hinterland. Map relations in the well-bedded and finely subdivided Upper Devonian and Mississippian units show clearly that a footwall syncline is present along most of the length of Mercury Ridge and that its southeastern limb is overturned northwestward to attitudes as shallow as $40^{\circ}$ (fig. 14) (Barnes and others, 1982; Cole, 1997). The excellent mapping in the Mercury quadrangle shows that the footwall section is the same under both edges of the Mercury klippe - the Mississippian limestone units in both blocks retain similar thicknesses and lithic characteristics. Because rapid lateral facies changes are typical in these Mississippian sections that represent carbonate accumulation near the shelf edge, it is unlikely that these similar sections could have formed at distant locales and serendipitously been juxtaposed by emplacement of the Mercury klippe (Stevens and others, 1991; Trexler and others, 1996).

These unusual foreland- and hinterland-vergent structures beneath the Mercury klippe appear to persist along the trace of the Spotted Range thrust to the east and northeast in the Ranger Mountains on the east side of Frenchman Flat. Reconnaissance mapping by Longwell and others (1965) in Clark County, by Tschanz and Pampeyan (1970) in Lincoln County, and by Guth (1990) in the Indian Springs quadrangle (fig. 14) (Cole, 1997) show consistent relationships. Along this trend, Cambrian hanging-wall rocks are faulted against Mississippian and Devonian rocks, and the latter locally show foreland-vergent overturning. Within about a kilometer northwest or west of the Spotted Range fault, the Cambrian hanging-wall rocks are faulted against Devonian rocks that are locally folded into a syncline that verges westward toward the hinterland. This style of deformation can be traced to Chert Ridge at the southern margin of Papoose Lake Valley (Tschanz and Pampeyan, 1970).

Guth (1990) argued that the faults that bound the Cambrian block in the center of the Mercury klippe and along the trace of the Spotted Range thrust are both Tertiary normal faults rather than contractional structures. In his model, these faults drop pieces of the Spotted Range hanging wall down to the west and northwest. We do not believe that this mechanism is tenable because it requires the Mississippian and Devonian rocks west of the Cambrian klippe to belong to the Spotted Range hanging wall (rather than its footwall). We believe the detailed stratigraphy of these rocks is so similar to that of the footwall south of the klippe (Barnes and others, 1982) that they must belong to the same plate. Guth's model also fails to account for the hinterland-vergent folding north of the klippe. Guth's model would unrealistically require that two major arcuate normal faults broke through previously folded terrane and yet remained closely parallel to each other for a distance of more than $50 \mathrm{~km}$.

If our conclusion is correct, that the Mercury klippe is different from the hanging wall of the Specter Range thrust, then the question of the source of the klippe arises. The internal stacking in the Mercury klippe and the extent of overturning in the southern Mississippian footwall indicates the primary direction of emplacement was toward the foreland (south-southeast). The source of the klippe may lie beneath Cenozoic fill in Frenchman Flat to the north, but no trace of a root zone is present in the geology on the east and north sides of the valley (Cole, 1997). This question is unresolvable without more information from the Ranger Mountains about the nature of the klippe-bounding faults.

The complex structure of the Spotted Range east of Mercury has been strongly overprinted by sinistral strike-slip faulting that accommodated the oroclinal bending of the range (Barnes and others, 1982; Guth, 1990). Tertiary sedimentary and volcanic rocks are preserved in irregular patches throughout the Spotted Range, and many of them are also strongly folded and displaced by sinistral-oblique faults (Barnes and others, 1982; Guth, 1990; Cole, unpub. mapping). Some of the included volcanic rocks are as old as late Oligocene (Barnes and others, 1982), which indicates at least some of the strain must be Miocene or younger in the Mercury Ridge area. However, the divergent folding beneath the Mercury klippe must be wholly pre-late Oligocene because the same type of folding is preserved in the Ranger Mountains east of Frenchman Flat, where no deformed Tertiary deposits are known and where no large component of oroclinal bending has occurred.

\section{DISCUSSION}

Several aspects of the structural relationships of preTertiary rocks at the Nevada Test Site, as described above, have implications for the regional structural geology of southern Nevada and southeastern California. This section focuses on these regional interpretations. Reinterpretations of the structural geology on the Nevada Test Site as a result of our work make up the Conclusions section of this report.

In the following discussion, we summarize our reinterpretations of pre-Tertiary structure in several ranges adjacent to the Nevada Test Site-Bare Mountain on the west, the Specter Range on the south, and the Spotted Range on the southeast. We then review published structural correlations between the Nevada Test Site and southeastern California and note where our data call for revisions to these correlations. Our work also bears on two regional issues included in this Discussion. We evaluate our conclusions in light of "oroflexural" deformation in southern Nevada and the age of the Las Vegas Valley shear zone. We conclude with discussion of the influence of crustal heterogeneity on contractional structures.

\section{IMPLICATIONS FOR REGIONAL STRUCTURE AND STRUCTURAL CORRELATIONS}

The descriptions and analysis presented above demonstrate that the Paleozoic rocks of the Nevada Test Site region chiefly record contractional deformation related to the Belted Range thrust and the CP thrust system. The Belted Range thrust places the Late Proterozoic section over Mississippian rocks, indicating as much as $7 \mathrm{~km}$ of stratigraphic throw. The 
Belted Range thrust verges toward the foreland, but the amount of lateral displacement cannot be quantified. A broad zone of duplex thrusting and folding characterizes the footwall of the Belted Range thrust. The duplex blocks mostly involve Devonian and Mississippian strata from the upper part of the footwall and tend to be limited in lateral and vertical extent. The contrast between Mississippian facies within the duplex zone and those in the footwall suggests that the floor thrust of the duplex zone represents significant lateral shortening.

The hinterland-vergent deformation of the CP thrust system is located on the foreland side of the foreland-vergent Belted Range thrust and duplex zone. This deformation is demonstrably younger than the foreland-vergent structures; it is most commonly expressed as bands of folds that overprint the foreland-vergent plates. Hinterland-vergent thrust faults are less commonly exposed, but can be inferred from age relationships and overturning in subsurface sections. Throughout western Yucca Flat, these thrusts place Cambrian and Ordovician rocks over the largely autochthonous Mississippian-Lower Permian section of Chainman Shale and Tippipah Limestone.

At Bare Mountain, we interpret the Panama thrust to belong to the CP thrust system. We agree with the assessment of Carr and Monsen (1988) that the characteristics of the Panama thrust indicate it cuts upsection toward the north through both the footwall and hanging wall. If the Secret Pass plate at the north end of Bare Mountain also belongs the Panama thrust plate, then the amount of stratigraphic throw decreases northward in the direction of tectonic transport (Carr and Monsen, 1988).

We believe the Specter Range thrust dies out eastward before reaching the Spotted Range and therefore does not correlate with the Spotted Range thrust in the Mercury klippe. This conclusion is reached in part because stratigraphic throw on the Specter Range thrust decreases eastward across the Specter Range and is projected to diminish to zero somewhere beneath Mercury Valley. The most compelling evidence, however, is that the stratigraphic section in the hanging wall of the Specter Range thrust can be traced in near continuity eastward to the central Spotted Range, where it forms the footwall of the Mercury klippe (Cole, 1997).

The Spotted Range thrust defines a distinctive tectonic element that can be traced from the southwest at the Mercury klippe through the Ranger Mountains (fig. 14) to the area of Chert Ridge in the northern Spotted Range (Cole, 1997). This zone is less than a few kilometers wide and consists of generally south- and east-dipping Cambrian dolomite, which is thrust toward the foreland against overturned Mississippian strata on the south and east, and faulted against Devonian and Mississippian strata on the north and west. Stratigraphic similarities in the middle Paleozoic rocks on either side of the Spotted Range thrust indicate that they belong to the same regional sheet. They are therefore inferred to be continuous beneath the southeast-vergent
Spotted Range thrust. However, footwall Mississippian strata on the northwest side of the Mercury klippe are overturned north (toward the hinterland) below the Spotted Range thrust plate, in apparent contradiction of this model. We admit no immediate solution to this paradox, and note that the root zone of the Spotted Range thrust is also unknown.

Snow and Wernicke (1989) and Snow (1992) documented a complex system of contractional structures in the Cottonwood Mountains area (fig. 1) and used the distinctive style and order of these structures as a tool for regional structural correlation. They describe, in geographic order from the hinterland toward the foreland, the Last Chance thrust (foreland-vergent), the White Top Mountain backfold (hinterland-vergent), and the Marble Canyon thrust (foreland-vergent).

We agree with Snow and Wernicke (1989) and Snow (1992) that the Last Chance thrust corresponds to the Belted Range thrust in the Nevada Test Site area and suggest a further continuation northward. Other faults correlated with the Last Chance thrust (table 1 in Snow, 1992) are the Grapevine thrust in the northern Grapevine Mountains, the Meiklejohn thrust in northern Bare Mountain, and the "CP thrust" (our Belted Range thrust) in the Rainier Mesa area. All these structures place Late Proterozoic strata on rocks as young as Carboniferous, and several retain a hanging-wall ramp (Snow, 1992). In further support of the correlation, the footwall duplexing we describe for the Belted Range thrust shares many characteristics with a complex zone of footwall duplex deformation, designated the "Racetrack duplex" below the Last Chance thrust in the Cottonwood Mountains (Snow, 1992). Along strike to the north, the Schofield Canyon thrust in the Quinn Canyon Range (Taylor and others, 1993) may correlate with the Belted Range thrust, based on sense of vergence, stratigraphic throw, and hanging-wall geometry.

Our new understanding of the CP thrust system (as redefined by Caskey and Schweickert, 1992, and herein) weakens the correspondence between it and the hinterland-vergent White Top Mountain backfold noted by Snow and Wernicke (1989). The hinterland-verging CP thrust system is characterized by both folding and thrusting along its entire length. Kink-style bands of folds (with amplitudes of meters to tens of meters) are broadly dispersed, but larger macroscopic folds typically occur adjacent to thrusts. West of the Nevada Test Site at Bare Mountain, we interpret the Panama thrust as part of the CP system because it breaks northward from its present outcrop to include the Secret Pass plate at the northern end of the range (Carr and Monsen, 1988). Our analysis shows that the CP system involves substantial local displacement on discrete thrusts and horsetailed fault splays-for example, in the low hills southeast of Mine Mountain. CP system thrusts in the Nevada Test Site area locally involve large stratigraphic separations. In contrast, the White Top Mountain backfold in the Cottonwood Mountains does not 
break the surface as a hinterland-vergent thrust. We have no argument with a general correlation of a hinterland-vergent deformation zone from the Nevada Test Site to the Cottonwood Mountains, but we are less confident with correlation of individual structures like the White Top backfold with specific elements of the CP thrust system.

South of the CP thrust zone in the southern Nevada Test Site area, the foreland-vergent Specter Range thrust places Late Proterozoic and Cambrian strata against a footwall ramp of Ordovician to Silurian age (Sargent and Stewart, 1971). Snow (1992) correlates this structure westward with the Schwaub Peak thrust in the southern Funeral Mountains (Late Proterozoic on Ordovician-Devonian footwall syncline; Wright and Troxel, 1993; Cole, 1997) and with the Marble Canyon thrust in the southern Cottonwood Mountains (fig. 1). These correlations are based on stratigraphic throw, footwall architecture, and relative position among the contractional structures of the region. We endorse these correlations.

\section{AGE OF OROFLEXURAL BENDING AND THE LAS VEGAS VALLEY SHEAR ZONE}

The zones of contractional deformation described above change direction by almost $90^{\circ}$ through the Nevada Test Site region. Structural trends are nearly east-west at Bare Mountain on the west, northeasterly in the Ranger Mountains east of Frenchman Flat, and north-northeast in the Belted Range in the north (figs. 1, 3). The foreland- and hinterland-vergent zones are subparallel throughout, a strike distance of more than $90 \mathrm{~km}$.

This "oroflexural bend" (Albers, 1967) has been interpreted to have formed during dextral slip along the Las Vegas Valley shear zone (Burchfiel, 1965; Guth, 1981; Wernicke and others, 1983). There is good evidence that the Las Vegas Valley shear zone separates regions of differential extension (Guth, 1981), with greater extension having taken place north of the shear zone between differentially tilted and arcuate ranges. Motion on the Las Vegas Valley shear zone produced synextensional basins between the arcuate ranges. Tephra in the basins date the extension at 20 to $15 \mathrm{Ma}$, continuing at a slower rate to at least $13 \mathrm{Ma}$ (Guth and others, 1988), similar to the time of extension adjacent to the Lake Mead fault system farther south (Bohannon, 1984). Although these sections date the time of discrete offset within the Las Vegas Valley shear zone, they do not necessarily date the arcuate bending of the ranges.

We believe, instead, that at least part of the "flexing" dates from the time of contractional deformation (Royse, 1983). We base this conclusion on available paleomagnetic data and on the differential deformation of the Paleozoic and Tertiary rocks in the southern Nevada Test Site. Paleomagnetic studies show much more vertical-axis rotation of Paleozoic rocks than of Tertiary rocks (see below). In addition, contrasts in style and amount of deformation between Paleozoic and Tertiary rocks in the "orocline" area on the Nevada Test Site suggest that much of the deformation occurred prior to the deposition of Oligocene and younger sediments. Finally, Tertiary sediments from the "orocline" area on the Nevada Test Site show no evidence of a local sediment source or of the local relief that might be expected during bending of the Paleozoic section (see below).

Paleomagnetic data constrain the formation of the bend to between Mississippian time and 13.2 Ma. Paleozoic rocks, both on the Nevada Test Site west of Frenchman Flat (M.R. Hudson, oral commun., 1996) and south of the Nevada Test Site (Gillette and Van Alstine, 1982; Nelson and Jones, 1987), document more than $60^{\circ}$ of vertical-axis rotation in the zone of oroclinal bending. In contrast, Miocene strata on the Nevada Test Site cannot have rotated more than $10^{\circ}$ about vertical axes since their deposition following 13.2 Ma (Hudson and others, 1994). To date, no definitive paleomagnetic data have been obtained for Tertiary units in the extensional basins north of the Las Vegas Valley shear zone or in the "oroflexural bend" area (e.g., the Spotted Range) on the Nevada Test Site.

Geologic relationships in the Spotted Range (Barnes and others, 1982) appear to preclude a period of rapid rotation 15-13 Ma that has been proposed by some workers for the ranges to the southeast on the north side of the Las Vegas Valley shear zone. Hudson and others (1994) suggested that the decrease in rate of extension prior to 13.2 Ma recorded in the sediments of extensional basins near the Gass Peak thrust (fig. 1) might indicate that most of the rotation occurred during a brief period between about $15 \mathrm{Ma}$ and $13 \mathrm{Ma}$. However, Tertiary sediments preserved in the internal valleys and on the northern flank of the Spotted Range do not record evidence of such deformation. These sediments contain tephra and ash-flow tuffs related to eruptions from the southwest Nevada volcanic field (Barnes and others, 1982; J.C. Yount, written commun., 1988; Sawyer and others, 1994) and dated at $29 \mathrm{Ma}, 26 \mathrm{Ma}, 15 \mathrm{Ma}$, and as young as $13 \mathrm{Ma}$. Conglomerates in the Tertiary section contain (1) volcanic clasts correlated with sources north and east of the Test Site, and (2) well-rounded durable clasts indicating distant source areas to the north and east (Barnes and others, 1982; J. Yount, oral commun., 1994). Both observations preclude the (nearby) Spotted Range as a primary source area for coarse clasts in these beds. Furthermore, the available evidence does not indicate any internal unconformities, erosion-truncated folds, or abrupt changes in clast sources or depositional regime through this time interval (29-13 Ma).

Structural evidence also is lacking for significant rotational deformation around $15 \mathrm{Ma}$. Although the Paleozoic rocks in the Spotted Range are clearly offset by faults with displacements of several kilometers (Barnes and others, 1982), similar displacements do not occur in the Tertiary rocks along strike. The sinistral strike-slip faulting in the Paleozoic section is consistent with the kinematics of arcuate 
bending of the Spotted Range. Therefore, if the faulting represents the "bending" event, most of this deformation occurred prior to the deposition of the Oligocene-Miocene section, i.e., prior to $29 \mathrm{Ma}$. Evidence of younger deformation includes local folding and reverse-faulting of Tertiary rocks within the Spotted Range and local truncation of Tertiary beds on the pre-Tertiary unconformity. The fact that this deformation does not coincide with a change in sedimentation patterns indicates that it was a relatively minor event.

In summary, we suggest that the arcuate bend existed in the Nevada Test Site region prior to deposition of Tertiary sediments, which began in about Oligocene time. Differential slip across the Las Vegas Valley shear zone in middle Miocene time probably reactivated some of the structures formed during bending in the Spotted Range and accommodated additional rotation and compression. Local truncation of Tertiary beds against Paleozoic rocks reflects passive draping of the incompetent Tertiary strata against the reactivated fault blocks of more rigid material.

\section{CRUSTAL INFLUENCE ON CONTRACTIONAL STRUCTURES}

The contractional structures in the Nevada Test Site region do not cross earlier facies patterns in the miogeoclinal sedimentary section; in fact, these structures may have been guided by crustal characteristics that established the Paleozoic sedimentological patterns.

The Belted Range thrust and its footwall duplex zone carry rocks toward the foreland that were originally deposited outboard of the shelf-slope break. The carbonate units contain conspicuous debris-flow conglomerates that record deposition on a slope, and the Mississippian clastic rocks were deposited in a deep marine turbidite trough between the offshore Antler orogenic rise and the continental slope edge (Cashman and Trexler, 1991, 1994; Trexler and others, 1996; Trexler and Cashman, 1997). These Belted Range duplex slices now lie on the Chainman Shale, which was deposited at the same time as the turbidites and submarine fans but in a separate, adjacent basin to the east. Evidence presented by Trexler and others (1996) and recounted above also documents a probable submarine rise between the Chainman basin and the turbidite trough - a rise that was apparently exposed to erosion in Late Devonian time (Mine Mountain-Shoshone Mountain area karst breccias). All these features together indicate the Belted Range thrust ramps formed at about the same position as the shelf-slope break. Thermal maturation data (Grow and others, 1994; Trexler and others, 1996; Cole and others, 1997) indicate the Belted Range thrust plate did not flatten out and bury the Chainman Shale basin, as one might expect on strictly mechanical grounds. This suggests a change in crustal mechanical properties near the shelf-slope break, which may have led to stagnation of the Belted Range sheet and extensive footwall deformation, rather than continued propagation of the sheet toward the foreland.

The hinterland-vergent deformation of the $\mathrm{CP}$ thrust system may also have been controlled by the crustal mechanical contrast that appears to have guided the foreland-vergent thrusting. The CP thrust system roots in a zone inboard of the Chainman basin and the inferred shelf-slope break, and it folds many of the Belted Range duplexes. The CP structures are interpreted to have large stratigraphic throw but limited regional shortening, as if they had rooted steeply in the miogeoclinal section and then flattened toward the hinterland in the direction of transport. The geometry of such deformation seems consistent with cutting back through an already thickened section formed by the Belted Range thrust. This feature suggests to us that the CP thrust system probably formed during the prolonged contractional event that began with Belted Range emplacement.

\section{SIGNIFICANT REVISIONS TO REGIONAL STRUCTURAL INTERPRETATION AT THE NEVADA TEST SITE}

1. Extent, continuity, orientation and timing of foreland- and hinterland-vergent structures. Facing belts of foreland- and hinterland-vergent folds and thrust faults form an arcuate zone across the Nevada Test Site, from Oak Spring Wash in the northeast to the Calico Hills in the west. The two belts are roughly parallel, but overlap locally. Conodont CAI data indicate that the rocks that form the lower plate to both thrusts were never deeply buried, suggesting that neither thrust system ever projected much farther than its present position (Trexler and others, 1996).

The zone of foreland-vergent folding and thrusting is principally footwall imbrication below the Belted Range thrust. The imbricate thrusts within this zone typically dip moderately to steeply west, but the thrust surface at the base of the imbricate stack is subhorizontal (see stratigraphic controls, below). Imbricate thrust sheets commonly contain east-verging hanging-wall anticlines, which plunge out along strike where the imbricate slices terminate in lateral ramps. Incipient pressure solution cleavage is uncommon but is developed in favorable rock types immediately below the thrusts or in the overturned limbs of macroscopic folds.

The hinterland-vergent system is much more widespread than previously recognized and is characterized by both folding and thrusting along its entire length on the Nevada Test Site. Macroscopic folds typically occur adjacent to thrusts; parallel kink-style bands of macroscopic to mesoscopic folds are more broadly dispersed. We have documented west- to northwest-vergent thrusting at Oak Spring Wash, in the subsurface under Yucca Flat, at Mine Mountain, 
and southeast of Mine Mountain at Eureka Ridge. Such thrusting was previously identified only at the CP Hills. Hinterland-vergent folding is found at Oak Spring Wash, the Smoky Hills, at the north end of Syncline Ridge, locally in the southern Eleana Range, throughout Mine Mountain, and in the Calico Hills. This, too, was previously identified only at the CP Hills.

Hinterland-vergent deformation clearly postdates the foreland-vergent deformation everywhere at the Nevada Test Site. Our findings contrast with conclusions of Snow (1992) that east- and west-vergent folds formed synchronously in the Cottonwood Mountains to the west. The relative age relationships are best illustrated in the Calico Hills, where an east-verging thrust is folded by a later, northwest-verging macroscopic fold. These northwest-verging folds are themselves refolded, at least locally (see below).

2. Evidence for a later phase of deformation due to north-south shortening. Local evidence in the Calico Hills indicates a later phase of deformation that accommodates north-south shortening, but it is not clear whether this is a late stage of the hinterland-vergent deformation or a separate event. North-vergent folding and thrusting are best developed at the southwestern margin of the Calico Hills where they overprint northwest-vergent folds (Cashman and Cole, 1996; Cole and Cashman, 1998). However, isolated folds that document north-south shortening occur locally throughout the Calico Hills and appear to represent the same event. Similarly, north-northwest-vergent folding and thrusting at the southeast edge of Mine Mountain overprints the westvergent folding that is the dominant expression of the hinterland-vergent deformation there. In both of these widely separated locations, the later north-south shortening is superimposed on west- to northwest-verging folds.

3. Stratigraphic controls on thrust geometry and style. The geometry and style of thrusting are stratigraphically controlled. Facies contrasts between thrust sheets (particularly in Devonian-Mississippian rocks) suggest that thrusts parallel Paleozoic facies patterns on a regional scale. The duplex in the footwall of the Belted Range thrust contains primarily the Mississippian Eleana Formation, duplicated along moderately dipping thrusts. However, a subhorizontal thrust forms the base of the duplex where the Eleana is emplaced over the coeval Chainman Shale. The contrast in conodont CAI as well as in Mississippian depositional facies indicates significant displacement across this basal thrust. Similarly, the CP thrust emplaces Cambrian and younger rocks westward over the Chainman Shale. Both relationships suggest that thrusts tended to flatten in the Chainman Shale.

4. Sinistral faulting. Sinistral slip has occurred along a series of north- to north-northwest-striking faults west and north of Yucca Flat. Although total offset is unknown, it is a minimum of several kilometers along each of at least six faults. The sinistral faulting is often associated with evidence for east-west shortening across the fault. Field relationships indicate that the sinistral faulting postdates (or is possibly synchronous with) the hinterland-vergent folding and thrusting. We have found sinistral faulting in the southern Eleana Range, at various sites around northwestern Yucca Flat, and in the Oak Spring Wash area at the northern edge of the Nevada Test Site (Cole and others, 1997; P. Cashman, unpub. mapping). Near Oak Spring Wash, there is evidence for sinistral offset along the Tippinip fault, an unnamed fault, and the (buried) Area 13 fault.

5. Lack of continuity between Specter Range and Spotted Range thrusts. The Specter Range thrust dies out eastward under Mercury Valley and does not project into the Spotted Range to connect with the Spotted Range thrust. Instead, the stratigraphic section in the hanging wall of the Specter Range thrust appears to be continuous with that in the footwall of the Spotted Range thrust. The Spotted Range thrust is therefore a separate, and structurally higher, thrust fault; its extent and geometry are poorly understood.

6. Age of oroclinal bending in the southern Nevada Test Site. The arcuate trend defined by the Specter Range-Spotted Range-Ranger Mountains-Halfpint Range alignment chiefly formed prior to the late Oligocene and may be as old as the regional contractional deformation that formed the Specter Range thrust and the Spotted Range thrust. Tertiary sediments that contain late Oligocene and Miocene volcanic deposits are folded and faulted within the Spotted Range, but they contain no coarse, proximal sediments derived from the adjacent Paleozoic strata, as would be expected if the arcuate bending and uplift were simultaneous with deposition.

7. Extensional faulting is not as significant as previously thought at Mine Mountain. Although there is prominent low-angle extensional faulting at Mine Mountain, it has commonly reactivated preexisting thrust surfaces and is not as structurally significant as previously stated (Cole and others, 1989). Flat-lying fault traces at Mine Mountain are characterized by the brecciation, iron staining, and polished, striated surfaces typical of extensional faults. However, overturned hanging-wall anticlines preserved in the upper-plate Devonian carbonate section record northwestward thrust emplacement of the Devonian over the Mississippian Eleana Formation. Steep to overturned bedding is also preserved in the footwall Eleana adjacent to the contact, indicating that the extensional faulting did not diverge much from the preexisting thrust surface. The direction of slip during extensional faulting is well documented (Hudson and Cole, 1993) and is roughly parallel to the strike of thrust-related structures.

\section{REFERENCES CITED}

Albers, J.P., 1967, Belt of sigmoidal bending and right-lateral faulting in the western Great Basin: Bulletin of the Geological Society of America, v. 78, p. 143-156.

Armstrong, R.L., 1968, Sevier orogenic belt in Nevada and Utah: Geological Society of America Bulletin, v. 79, p. 429-458.

Barker, C.E., 1994, Thermal and petroleum generation history of the Mississippian Eleana Formation and Tertiary source rocks, 
Yucca Mountain area, southern Nye County, Nevada: U.S. Geological Survey Open-File Report 94-161, 42 p.

Barnes, Harley, and Christiansen, R.L., 1967, Cambrian and Precambrian rocks of the Groom district, Nevada, southern Great Basin: U.S. Geological Survey Bulletin 1244-G, 34 p.

Barnes, Harley, Ekren, E.B., Rodgers, C.L., and Hedlund, D.C., 1982, Geologic and tectonic maps of the Mercury quadrangle, Nye and Clark Counties, Nevada: U.S. Geological Survey Miscellaneous Investigations Map I-1197, scale 1:24,000.

Barnes, Harley, Hinrichs, E.N., McKeown, F.A., and Orkild, P.P., 1963, U.S. Geological Survey investigations of Yucca Flat, Nevada Test Site, Part A - Geology of the Yucca Flat area: U.S. Geological Survey Technical Letter NTS-45, Part A, 196 p.

Barnes, Harley, Houser, F.N., and Poole, F.G., 1963, Geologic map of the Oak Spring quadrangle, Nye County, Nevada: U.S. Geological Survey Geologic Quadrangle Map GQ-214, scale $1: 24,000$.

Barnes, Harley, and Poole, F.G., 1968, Regional thrust-fault system in Nevada Test Site and vicinity, in Eckel, E.B., ed., Nevada Test Site: Geological Society of America Memoir 110, p. 233-238.

Bohannon, R.G., 1984, Nonmarine sedimentary rocks of Tertiary age in the Lake Mead region, southeastern Nevada and northwestern Arizona: U.S. Geological Survey Professional Paper $1259,72 \mathrm{p}$

-1992, Geologic map of the Weiser Ridge quadrangle, Clark County, Nevada: U.S. Geological Survey Geologic Quadrangle Map GQ-1714, scale 1:24,000.

Burchfiel, B.C., 1965, Structural geology of the Specter Range quadrangle, Nevada, and its regional significance: Geological Society of America Bulletin, v. 76, p. 175-192.

Carr, M.D., and Monsen, S.A., 1988, A field trip guide to the geology of Bare Mountain, in Weide, D.L., and Faber, M.L., eds., This Extended Land, Geological Journeys in the Southern Basin and Range: Geological Society of America, Cordilleran Section, Field Trip Guidebook, p. 50-57.

Carr, W.J., 1974, Summary of tectonic and structural evidence for stress orientation at the Nevada Test Site: U.S. Geological Survey Open-File Report 74-176, 53 p.

1984, Regional structural setting of Yucca Mountain, southwestern Nevada, and late Cenozoic rates of tectonic activity in part of the southwestern Great Basin, Nevada and California: U.S. Geological Survey Open-File Report 84-854, 109 p.

1988, Volcano-tectonic setting of Yucca Mountain and Crater Flat, southwestern Nevada, in Carr, M.D., and Yount, J.C., eds., Geologic and Hydrologic Investigations of a Potential Nuclear Waste Repository Site at Yucca Mountain: U.S. Geological Survey Bulletin 1790, p. 35-50.

Cashman, P.H., and Cole, J.C., 1996, Structure of Paleozoic rocks in the Calico Hills, Nevada Test Site-Implications for regional reconstructions [abs.]: Eos, Transactions of the American Geophysical Union, v. 77, no. 46, p. F641.

Cashman, P.H., and Trexler, J.H., Jr., 1991, The Mississippian Antler foreland and continental margin in southern Nevada-The Eleana Formation reinterpreted, in Cooper, J.D., and Stevens, C.H., eds., Paleozoic Paleogeography of the Western United States-II: Pacific Section, Society of Economic Paleontologists and Mineralogists, v. 67, p. 271-280.

1994, The case for two, coeval, Mississippian sections at the Nevada Test Site, in McGill, S.F., and Ross, T.M., eds., Geological Investigations of an Active Margin: San Bernardino,
Calif., Geological Society of America Cordilleran Section Guidebook, 1994, p. 76-81.

Caskey, S.J., 1991, Mesozoic and Cenozoic structural geology of the CP Hills, Nevada Test Site, Nye County, Nevada; and regional implications: Reno, University of Nevada, M.S. dissertation, 133 p., 3 plates, 1:24,000 scale.

Caskey, S.J., and Schweickert, R.A., 1992, Mesozoic deformation in the Nevada Test Site and vicinity: Implications for the structural framework of the Cordilleran fold and thrust belt and Tertiary extension north of Las Vegas Valley: Tectonics, v. 11, p. 1314-1331.

Cole, J.C., 1987, Breakup of an allochthonous slab-Origin of the Yucca Flat basin, Nevada Test Site [abs.]: Geological Society of America Abstracts with Programs, v. 19, no. 7, p. 623.

1997, Major structural controls on the distribution of preTertiary rocks, Nevada Test Site vicinity, Nye County, Nevada: U.S. Geological Survey Open-File Report 97-533, scale 1:100,000, $19 \mathrm{p}$.

Cole, J.C., and Cashman, P.H., 1997, Geologic map of the Mine Mountain area, Nevada Test Site, southern Nevada: U.S. Geological Survey Open-File Report 97-697, scale 1:12,000, 8 p.

1998, Geologic map of Paleozoic rocks in the Calico Hills, Nevada Test Site, southern Nevada: U.S. Geological Survey Open-File Report 98-101, scale 1:6,000, 17 p.

Cole, J.C., Harris, A.G., Lanphere, M.A., Barker, C.E., and Warren, R.G., 1993, The case for pre-middle Cretaceous extensional faulting in northern Yucca Flat, southwestern Nevada [abs.]: Geological Society of America Abstracts with Programs, v. 25, no. 5 , p. 22

Cole, J.C., Harris, A.G., and Wahl, R.R., 1997, Subcrop geologic map of pre-Tertiary rocks in the Yucca Flat and northern Frenchman Flat areas, Nevada Test Site, southern Nevada: U.S. Geological Survey Open-File Report 97-678, scale 1:48,000, $24 \mathrm{p}$.

Cole, J.C., Trexler, J.H., Jr., Cashman, P.H., and Hudson, M.R., 1994, Structural and stratigraphic relations of Mississippian rocks at the Nevada Test Site, in McGill, S.F., and Ross, T.M., eds., Geological Investigations of an Active Margin: San Bernardino, Calif., Geological Society of America Cordilleran Section Guidebook, 1994, p. 66-75.

Cole, J.C., Wahl, R.R., and Hudson, M.R., 1989, Structural relations within the Paleozoic basement of the Mine Mountain block; implications for interpretations of gravity data in Yucca Flat, Nevada Test Site: Santa Barbara, Calif., Proceedings from Fifth Symposium on Containment of Underground Nuclear Explosions, Lawrence Livermore National Laboratory, CONF-8909163, v. 2, p. 431-456.

Dettinger, M.D., 1989, Distribution of carbonate-rock aquifers in southern Nevada and the potential for their development-Summary of findings, 1985-1988: Carson City, Nev., Program for the Study and Testing of Carbonate-Rock Aquifers in Eastern and Southern Nevada, Summary Report No. 1, 37 p.

Ekren, E.B., Anderson, R.E., Rogers, C.L., and Noble, D.C., 1971, Geology of northern Nellis Air Force Base Bombing and Gunnery Range, Nye County, Nevada: U.S. Geological Survey Professional Paper 651, $91 \mathrm{p}$.

Ekren, E.B., Rogers, C.L., Anderson, R.E., and Botinelly, Theodore, 1967, Geologic map of the Belted Peak quadrangle, Nye County, Nevada: U.S. Geological Survey Geologic Quadrangle Map GQ-606, scale 1:62,500. 
Epstein, A.G., Epstein, J.B., and Harris, L.D., 1977, Conodont color alteration-An index to organic metamorphism: U.S. Geological Survey Professional Paper 995, 27 p.

Fleck, R.J., 1970, Tectonic style, magnitude, and age of deformation in the Sevier orogenic belt in southern Nevada and eastern California: Bulletin of the Geological Society of America, v. 81 , p. $1705-1720$.

Gibbons, A.B., Hinrichs, E.N., Hansen, W.R., and Lemke, R.W., 1963, Geology of the Rainier Mesa quadrangle, Nye County, Nevada: U.S. Geological Survey Geologic Quadrangle Map GQ-215, scale 1:24,000.

Gillette, S.L., and Van Alstine, D.R., 1982, Remagnetization and tectonic rotation of upper Precambrian and lower Paleozoic strata from the Desert Range, southern Nevada: Journal of Geophysical Research, v. 87, p. 10929-10953.

Grow, J.A., Barker, C.E., and Harris, A.G., 1994, Oil and gas exploration near Yucca Mountain, southern Nevada: Las Vegas, Nev., Proceedings of the American Nuclear Society International High-Level Radioactive Waste Management Conference, May 22-26, 1994, p. 1-18.

Guth, P.L., 1981, Tertiary extension north of the Las Vegas Valley shear zone, Sheep and Desert Ranges, Clark County, Nevada: Geological Society of America Bulletin, v. 92, p. 763-771.

1990, Superposed Mesozoic and Cenozoic deformation, Indian Springs quadrangle, southern Nevada, in Wernicke, B.P., ed., Basin and Range Extensional Tectonics Near the Latitude of Las Vegas, Nevada: Geological Society of America Memoir 176, p. 237-249.

Guth, P.L., Schmidt, D.L., Deibert, Jack, and Yount, J.C., 1988, Tertiary extensional basins of northwestern Clark County, Nevada, in Weide, D.L., and Faber, M.L., eds., This Extended Land-Geological Journeys in the Southern Basin and Range: Geological Society of America, Cordilleran Section, Field Trip Guidebook, p. 239-254.

Hamilton, W., 1988, Detachment faulting in the Death Valley region, California and Nevada, in Carr, M.D. and Yount, J.C., eds., Geologic and Hydrologic Investigations of a Potential Nuclear Waste Repository Site at Yucca Mountain: U.S. Geological Survey Bulletin 1790, p. 51-85.

Hinrichs, E.N., 1968, Geologic map of the Camp Desert Rock quadrangle, Nye County, Nevada: U.S. Geological Survey Geologic Quadrangle Map GQ-726, scale 1:24,000.

Houser, F.N., and Poole, F.G., 1960, Preliminary geologic map of the Climax stock and vicinity, Nye County, Nevada: U.S. Geological Survey Miscellaneous Investigations Map I-328, scale 1:5,000.

Hudson, M.R., 1992, Paleomagnetic data bearing on the origin of arcuate structures in the French Peak-Massachusetts Mountain area of southern Nevada: Geological Society of America Bulletin, v. 104, p. 581-594.

1997, Structural geology of the French Peak accommodation zone, Nevada Test Site, southwestern Nevada: U.S. Geological Survey Open-File Report 97-56, 26 p., scale 1:12,000.

Hudson, M.R., and Cole, J.C., 1993, Kinematics of faulting in the Mine Mountain area of southern Nevada: Evidence for premiddle Miocene extension [abs.]: Geological Society of America Abstracts with Programs, v. 25, no. 5, p. 55.

Hudson, M.R., Sawyer, D.A., and Warren, R.G., 1994, Paleomagnetism and rotation constraints for the middle Miocene south- western Nevada volcanic field: Tectonics, v. 13, no. 2, p. 258-277.

Jayko, A.J., 1990, Shallow crustal deformation in the Pahranagat area, southern Nevada, in Wernicke, Brian, ed., Basin and Range Extensional Tectonics Near the Latitude of Las Vegas, Nevada: Geological Society of America Memoir 176, p. 213-236.

Johnson, M.S., and Hibbard, D.E., 1957, Geology of the Atomic Energy Commission Nevada Proving Grounds area, Nevada: U.S. Geological Survey Bulletin 1021-K, p. 333-383.

Laczniak, R.J., Cole, J.C., Sawyer, D.A., and Trudeau, D.A., 1996, Summary of hydrogeologic controls on ground-water flow at the Nevada Test Site, Nye County, Nevada: U.S. Geological Survey Water Resources Investigations Report 96-4109, 59 p.

Longwell, C.R., Pampeyan, E.H., Bowyer, Ben, and Roberts, R.J., 1965, Geology and mineral deposits of Clark County, Nevada: Nevada Bureau of Mines and Geology Bulletin 62, 218 p.

McKay, E.J., and Williams, W.P., 1964, Geologic map of the Jackass Flats quadrangle, Nye County, Nevada: U.S. Geological Survey Geologic Quadrangle Map GQ-368, scale 1:24,000.

McKeown, F.A., Healey, D.L., and Miller, C.H., 1976, Geology of the Yucca Lake quadrangle, Nye County, Nevada: U.S. Geological Survey Geologic Quadrangle Map GQ-1327, scale $1: 24,000$.

Minor, S.A., 1995, Superposed local and regional paleostresses: Fault-slip analysis of Neogene extensional faulting near coeval caldera complexes, Yucca Flat, Nevada: Journal of Geophysical Research, v. 100, no. B6, p. 10507-10528.

Monsen, S.A., Carr, M.D., Reheis, M.C., and Orkild, P.P., 1992, Geologic map of Bare Mountain, Nye County, Nevada: U.S. Geological Survey Miscellaneous Investigations Map I-2201, scale $1: 24,000$.

Naeser, C.W., and Maldonado, Florian, 1981, Fission-track dating of the Climax and Gold Meadows stocks, Nye County, Nevada: U.S. Geological Survey Professional Paper 1199-E, p. 45-46.

Nelson, M.R., and Jones, C.H., 1987, Paleomagnetism and crustal rotations along a shear zone, Las Vegas Range, southern Nevada: Tectonophysics, v. 6, p. 13-33.

Orkild, P.P., 1963, Geologic map of the Tippipah Spring quadrangle, Nye County, Nevada: U.S. Geological Survey Geologic Quadrangle Map GQ-213, scale 1:24,000.

1968, Geologic map of the Mine Mountain quadrangle, Nye County, Nevada: U.S. Geological Survey Geologic Quadrangle Map GQ-746, scale 1:24,000.

Orkild, P.P., and O'Connor, J.T., 1970, Geologic map of the Topopah Spring quadrangle, Nye County, Nevada: U.S. Geological Survey Geologic Quadrangle Map GQ-849, scale $1: 24,000$.

Palmer, A.R., and Halley, R.B., 1979, Physical stratigraphy and trilobite biostratigraphy of the Carrara Formation (Lower and Middle Cambrian) in the southern Great Basin: U.S. Geological Survey Professional Paper 1047, 131 p.

Poole, F.G., Houser, F.N., and Orkild, P.P., 1961, Eleana Formation of Nevada Test Site and vicinity, Nye County, Nevada: U.S. Geological Survey Professional Paper 424-D, p. D104-D111.

Reso, Anthony, 1963, Composite columnar section of exposed Paleozoic and Cenozoic rocks in the Pahranagat Range, Lincoln County, Nevada: Bulletin of the Geological Society of America, v. 74, p. 901-918. 
Rogers, C.L., and Noble, D.C., 1969, Geologic map of the Oak Spring Butte quadrangle, Nye County, Nevada: U.S. Geological Survey Geologic Quadrangle Map GQ-822, scale 1:24,000.

Royse, Frank, 1983, Comment on "Magnitude of crustal extension in the southern Great Basin:" Geology, v. 11, p. 495-496.

Sargent, K.A., and Orkild, P.P., 1973, Geologic map of the Wheelbarrow Peak-Rainier Mesa area, Nye County, Nevada: U.S. Geological Survey Miscellaneous Investigations Map I-754, scale $1: 48,000$.

Sargent, K.A., and Stewart, J.H., 1971, Geologic map of the Specter Range NW quadrangle, Nye County, Nevada: U.S. Geological Survey Geologic Quadrangle Map GQ-884, scale 1:24,000.

Sawyer, D.A., Fleck, R.J., Lanphere, M.A., Warren, R.G., Broxton, D.E., and Hudson, M.R., 1994, Episodic caldera volcanism in the Miocene southwestern Nevada volcanic field: Revised stratigraphic framework, $\mathrm{Ar}^{40} / \mathrm{Ar}^{39}$ geochronology, and implications for magmatism and extension: Geological Society of America Bulletin, v. 106, p. 1304-1318.

Simonds, F.W., 1989, Geology and hydrothermal alteration at the Calico Hills, Nye County, Nevada: Boulder, University of Colorado, M.S. dissertation, $136 \mathrm{p}$.

Snow, J.K., 1992, Large magnitude Permian shortening and continental-marginal tectonics in the southern Cordillera: Geological Society of America Bulletin, v. 104, p. 80-105.

Snow, J.K., and Wernicke, Brian, 1989, Uniqueness of geological reconstructions: An example from the Death Valley extended terrane: Geological Society of America Bulletin, v. 101, p. $1351-1362$.

Stevens, C.H., Stone, P., and Belasky, P., 1991, Paleogeographic and structural significance of an Upper Mississippian facies boundary in southern Nevada and east-central California: Geological Society of America Bulletin, v. 103, p. 876-885.

Stewart, J. H., 1980a, Geology of Nevada-A discussion to accompany the geologic map of Nevada: Nevada Bureau of Mines and Geology Special Publication 4, $136 \mathrm{p}$.

1980b, Regional tilt patterns of late Cenozoic basin-range blocks, Western United States: Geological Society of America Bulletin, v. 91, p. 460-464.

Stone, Paul, and Stevens, C.H., 1988, Pennsylvanian and Early Permian paleogeography of east-central California: Implications for the shape of the continental margin and the timing of continental truncation: Geology, v. 16, p. 330-333.

Taylor, W.J., Bartley, J.M., Fryxell, J.E., Schmitt, J.G., and Vandervoort, D.S., 1993, Tectonic style and regional relations of the Central Nevada thrust belt, in Lahren, M.M., Trexler, J.H., Jr., and Spinosa, C., eds., Crustal Evolution of the Great Basin and Sierra Nevada: Geological Society of America Fieldtrip Guide-

Published in the Central Region, Denver, Colorado

Manuscript approved for publication June 16, 1998

Edited by Richard W. Scott, Jr.

Graphics prepared by William E. Sowers and Carol Quesenberry; use made of author-drafted material

Photocomposition by William E. Sowers and Carol Quesenberry book, Department of Geological Sciences, University of Nevada, Reno, p. 57-96.

Titus, A.L., 1992, Mid-Carboniferous biostratigraphy and ammonoid paleontology of the upper Eleana Formation (unit J, upper quartzite subunit), Syncline Ridge: Fayetteville, University of Arkansas, M.S. dissertation.

Trexler, J.H., Jr., and Cashman, P.H., 1997, A southern Antler foredeep submarine fan: The Mississippian Eleana Formation, Nevada Test Site: Journal of Sedimentary Research, v. 67, no. 6, p. 1044-1059.

Trexler, J.H., Jr., Cole, J.C., and Cashman, P.H., 1996, Middle Devonian-Mississippian stratigraphy on and near the Nevada Test Site: Implications for hydrocarbon potential: Bulletin of the American Association of Petroleum Geologists, v. 80, p. 1736-1762.

Tschanz, C.M., and Pampeyan, E.H., 1970, Geology and mineral deposits of Lincoln County, Nevada: Nevada Bureau of Mines and Geology Bulletin 73, 188 p.

U.S. Geological Survey, 1974, Results of exploration of the Baneberry site, early 1971: U.S. Geological Survey Report USGS-474-145, 94 p.

Wahl, R.R., Sawyer, D.A., Carr, M.D., Minor, S.M., Cole, J.C., Swadley, WC, Laczniak, R.J., Warren, R.G., Green, K.S., and Engle, C.M., 1997, Digital geologic map database of the Nevada Test Site area, Nevada: U.S. Geological Survey Open-File Report 97-140, scale 1:100,000, $47 \mathrm{p}$.

Wernicke, Brian, Spencer, J.E., and Guth, P.L., 1983, Reply for "Magnitude of crustal extension in the southern Great Basin:" Geology, v. 11, no. 8, p. 496-497.

Wernicke, Brian, Axen, G.J., and Snow, J.K., 1988, Basin and Range extensional tectonics at the latitude of Las Vegas: Geological Society of America Bulletin, v. 100, p. 1738-1757.

Wernicke, Brian, Snow, J.K., and Walker, J.D., 1988, Correlation of Mesozoic thrusts in the southern Great Basin and their possible indication of $250-300 \mathrm{~km}$ of Neogene crustal extension, in Weide, D.L., and Faber, M.L., eds., This Extended Land, Geological Journeys in the Southern Basin and Range: Geological Society of America Field Trip Guidebook, p. 255-268.

Winograd, I.J., and Thordarson, William, 1975, Hydrogeologic and hydrogeochemical framework, south-central Great Basin, Nevada-California, with special reference to the Nevada Test Site: U.S. Geological Survey Professional Paper 712-C, 126 p.

Wright, L.A., and Troxel, B.W., 1993, Geologic map of the central and northern Funeral Mountains and adjacent areas, Death Valley region, southern California: U.S. Geological Survey Miscellaneous Investigations Map I-2305, scale 1:48,000. 